\title{
CONTROL OF REPRODUCTION \\ IN NILE TILAPIA (OREOCHROMIS NILOTICUS) BY MANIPULATION OF ENVIRONMENTAL FACTORS
}

\author{
Dissertation \\ for the Doctoral Degree \\ at the Faculty of Agricultural Sciences, \\ Georg-August-Universität Göttingen
}

presented by

Boris Adrien de Lapeyre

born in Curepipe (Mauritius)

Göttingen, December 2007 
D 7

1. Referee: Prof. Dr. G. Hörstgen-Schwark

2. Co-referee: Prof. Dr. Dr. hc. U. ter Meulen

Date of disputation: 1. February, 2008 
Zusammenfassung

Chapter 1 Introduction 11

Biology 13

$\begin{array}{ll}\text { Physiology of reproduction } & 15\end{array}$

Hormonal regulation $\quad 17$

External impulses in reproduction $\quad 21$

Scope of the thesis $\quad 25$

$\begin{array}{ll}\text { References } & 27\end{array}$

Chapter 2 Temperature manipulation 32

Introduction $\quad 33$

Materials and methods $\quad 34$

$\begin{array}{ll}\text { Results } & 37\end{array}$

Discussion $\quad 41$

$\begin{array}{ll}\text { References } & 43\end{array}$

Chapter $3 \quad$ Stocking density and photoperiod manipulation 45

Introduction $\quad 46$

Materials and method $\quad 47$

Results $\quad 50$

Discussion $\quad 53$

Conclusion $\quad 55$

References $\quad 56$ 
$\begin{array}{lll}\text { Chapter } 4 & \text { Repeated stocking density manipulation } & 58\end{array}$

Introduction $\quad 59$

$\begin{array}{ll}\text { Materials and method } & 60\end{array}$

Results $\quad 65$

$\begin{array}{ll}\text { Discussion } & 69\end{array}$

$\begin{array}{ll}\text { Conclusion } & 72\end{array}$

$\begin{array}{ll}\text { References } & 73\end{array}$

$\begin{array}{lll}\text { Chapter } 5 & \text { Discussion } & 74\end{array}$

$\begin{array}{ll}\text { Part I } & 75\end{array}$

$\begin{array}{ll}\text { Part II } & 82\end{array}$

$\begin{array}{ll}\text { References } & 88\end{array}$ 


\section{Zusammenfassung}

Die Produktion von Niltilapien (Oreochromis niloticus) gewinnt seit einigen Jahren zunehmend an Bedeutung. Als Warmwasserspezies mit geringen Futteransprüchen, hohem Wachstumspotential und schmackhaftem Fleisch ist diese anspruchslose Spezies inzwischen nach dem Karpfen die häufigste produzierte Fischart weltweit in der Aquakultur. Um gezielte Anpaarungen mittels künstlicher Befruchtung im Rahmen von Zuchtprogrammen (inklusive Genomveränderungen) zu einem festgelegten Zeitpunkt durchführen zu können, bedarf es einer termingerechten Gewinnung großer Chargen von abgestreiften Eiern. Bei saisonalen Fischen wie dem Lachs, können geänderte Umweltbedingungen wie die Tageslänge und die Haltungstemperatur gezielt eingesetzt werden, um das Ablaichen der Laichfischbestände zu beeinflussen. In ähnlicher Weise wurden in der vorliegenden Arbeit verschiedener Haltungsfaktoren wie Temperatur, Besatzdichte und Photoperiode auf die Reproduktion von weiblichen O. niloticus Laichern der Population Lake Manzala geprüft.

Das Ziel der Untersuchungen war es, Haltungsmöglichkeiten zu eruieren, die möglichst viele weibliche Fische in einem Zeitraum von 5 Tagen zum Ablaichen bringen. Die Ablaichhäufigkeit wurde definiert als der relative Anteil von Weibchen, die innerhalb dieses Zeitraumes von 5 Tagen ablaichten. Um die Fruchtbarkeit und die Eiqualität zu bewerten, wurde die Anzahl an Eiern pro Gramm Körpermasse des Rogeners sowie der Prozentsatz von geschlüpften und schwimmfähigen Brütlingen erfasst.

Im ersten Versuchsdurchgang wurden die weiblichen Laichfische eine Woche lang an eine Wassertemperatur von $28^{\circ} \mathrm{C}$ akklimatisiert bevor die Temperatur für einen Zeitraum von 7 (Gruppe I), 14 (Gruppe II) oder 28 Tagen (Gruppe III) auf $22^{\circ} \mathrm{C}$ herabgesetzt wurde. Danach wurden die Laichfische wieder bei einer Wassertemperatur von $28^{\circ} \mathrm{C}$ gehalten. In den entsprechenden Kontrollgruppen wurden die Fische durchgehend bei einer Wassertemperatur von $28^{\circ} \mathrm{C}$ gehalten. Die Ablaichhäufigkeiten in Gruppe II und Gruppe III waren mit $40 \%$ und $31 \%$ signifikant höher als in den jeweiligen Kontrollen (13\%, 11\%). Die Prozentzahlen von geschlüpften Brütlingen waren dagegen in den Kontrollen (Gruppe II: 74\%, Gruppe III: 58\%) doppelt so hoch als in den Versuchsgruppen II und III.

Im zweiten Versuchsdurchgang wurden 2 Versuchsvarianten erprobt.

In der ersten Variante wurden die Weibchen eine Woche zusammen in ein $1 \mathrm{~m}^{3}$ Haltungsbecken verbracht, danach einzeln in kleinen $0,3 \mathrm{~m}^{3}$ fassende Aquarien umgesetzt, wo 
sie für eine Woche verblieben. Dabei wurde die Besatzdichte im Verhältnis 7:1 (von 48 auf 7 $\mathrm{kg} / \mathrm{m}^{3}$ ) reduziert.

In der zweiten Variante wurden die Weibchen für 3 Wochen und 4 Wochen zusammen in einem $1 \mathrm{~m}^{3}$ Haltungsbecken bei einer Photoperiode von $6 \mathrm{~h}$ Licht und $18 \mathrm{~h}$ Dunkelheit (6L:18D) gehalten. Danach wurden sie einzeln in kleine $0,3 \mathrm{~m}^{3}$ fassende Aquarien umgesetzt, wo sie bei einer Photoperiode von $12 \mathrm{~h}$ Licht und $12 \mathrm{~h}$ Dunkelheit (12L:12D) für eine Woche verblieben. Hier erfolgte eine Reduzierung der Besatzdichte wie in der zweiten Varianten im Verhältnis 4:1.

Im letzen Versuchsdurchgang, wie in der ersten Variante des zweiten Versuchsdurchgangs, wurden die Weibchen eine Woche zusammen in ein $1 \mathrm{~m}^{3}$ Haltungsbecken verbracht, danach einzeln in kleine $0,3 \mathrm{~m}^{3}$ fassende Aquarien umgesetzt, wo sie für eine Woche verblieben. Dabei wurde die Besatzdichte im Verhältnis 4:1 reduziert. Das Procedere wurde dreimal (Wiederholung 1, 2 und 3) mit den gleichen Laichfischen wiederholt.

Es zeigte sich, dass bei einer großen Änderung der Besatzdichte eine höhere Ablaichhäufigkeit (Zweiter Versuchsdurchgang: 32\%) erzielt wurde als bei einer geringen Änderung (Dritter Versuchsdurchgang - Wiederholung 1: 25\%). Ferner bedingte die wiederholte Behandlung derselben Fische (Dritter Versuchsdurchgang) einem Anstieg der Ablaichhäufigkeit von Wiederholung $1 \mathrm{zu}$ Wiederholung 3 (25\%, 26\%, 39\%). Die Kombination einer veränderten Photoperiode über einem Zeitraum von 3 Wochen mit einer geringen Veränderung der Besatzdichte (Zweiter Versuchsdurchgang - zweite Variante) erbrachte insgesamt die höchste Ablaichhäufigkeit (65\%). Der Prozentsatz von geschlüpften und schwimmfähigen Brütlingen im zweiten Versuchsdurchgang war im Durchschnitt in allen Versuchsvarianten des zweiten und dritten Versuchsdurchgangs höher als im ersten Versuchsdurchgang.

In dieser Studie wurde erstmals eine systematische Testung der Umweltfaktoren Wassertemperatur, Besatzdichte und Photoperiode auf das Ablaichen bei großen Tierzahlen weiblicher $O$. niloticus Laicher $(\mathrm{N}=674)$ untersucht. Es wurde eindeutig gezeigt, dass Tilapienrogener für eine planmäßige Laichgewinnung in ihrem Laichverhalten beeinflusst werden können. Um eine große Anzahl an Eiern in einen definierten Zeitraum zu bekommen, kann eine starke Veränderung der Besatzdichte vorgenommen werden, was relativ einfach 
und schnell $\mathrm{zu}$ realisieren ist. Steht mehr Zeit zur Verfügung, empfiehlt es sich, eine Veränderung der Besatzdichte in Kombination mit einer dreiwöchigen Photoperiode von 6L:18D einzusetzen.

Es bleibt zu prüfen, ob der Auslöser, der das Ablaichen der Rogener bewirkt z.B. nach einem Wechsel der Besatzdichte, genetisch determiniert ist, um möglicherweise durch Selektion Zuchtlinien mit höheren Ablaichhäufigkeiten erstellen zu können. 


\section{Summary}

Over the past years, the production of the Nile tilapia (Oreochromis niloticus) has gained increasing importance worldwide. With its low feed requirements, high growth potential and very palatable flesh, this undemanding warm water species is now second only to the carp in terms of global quantities of farm raised fish. There is a need for a scheduled production at a predetermined point in time of large batches of stripped eggs in order to perform specific matings by means of artificial fertilisation within the scope of breeding programs (including genome modifications). In seasonal fish such as salmon, changes in environmental conditions such as day length and water temperature can be systematically applied with the aim of influencing the spawning of the broodstock. Similarly, the present study tested the effect of various management factors such as temperature, stocking density and photoperiod on the reproduction of female $O$. niloticus breeders of the Lake Manzala population.

The aim of the study was to determine which holding conditions are most propitious in inducing the greatest number of breeders to spawn within an interval of 5 days. The spawning frequency was defined as the proportion of female breeders that spawned within this given interval of 5 days. To assess fertility and egg quality, the data collected were the number of eggs per gram body mass of the female breeders as well as the percentage of hatchlings and swim-up fry.

During the first set of trials, the female breeders were kept at a water temperature of $28^{\circ} \mathrm{C}$ until they were acclimatised, before the water temperature was reduced to $22^{\circ} \mathrm{C}$ for a period of 7 days (group I), 14 days (group II) and 28 days (group III). Subsequently the water temperature was returned to the initial $28^{\circ} \mathrm{C}$ for all three groups of female breeders. There were three corresponding control groups whose water temperature was kept constant at $28^{\circ} \mathrm{C}$. The spawning rates in group II and group III (40\% and 31\%) were significantly higher than those of the corresponding control groups $(13 \%, 11 \%)$. However, the percentage of hatchlings in the control (group II: 74\%, group III: 58\%) was twice as high as in the test groups II and III.

During the second set of trials, 2 experiments were tested.

In the first experiment, all the females were kept together in an aquarium of volume $1 \mathrm{~m}^{3}$ for one week. They were then moved to individual $0.3 \mathrm{~m}^{3}$ aquaria where they remained for one week. In the process the stocking density was reduced in a ratio of 7:1 (from 48 to $7 \mathrm{~kg} \mathrm{~m}^{-3}$ ). 
In the second experiment, the females were all kept together in a $1 \mathrm{~m}^{3}$ aquarium for 3 weeks and 4 weeks with a photoperiod of 6 hours of light and 18 hours of darkness (6L:18D). They were then moved to small individual $0.3 \mathrm{~m}^{3}$ aquaria were they remained for one week at a photoperiod of $12 \mathrm{~h}$ light and $12 \mathrm{~h}$ darkness (12L:12D). At this point the same reduction of stocking density as in the second experiment occurred (ratio of 4:1).

During the last set of trials as in the first experiment of the second set of trials, all the females were kept together in an aquarium of volume $1 \mathrm{~m}^{3}$ for one week. Subsequently, they were then moved to individual $0.3 \mathrm{~m}^{3}$ aquaria where they remained for one week. In the process the stocking density was reduced in a ratio of $4: 1$. The procedure was then repeated three times (repeat 1,2 and 3) with the same female breeders

It was shown that the spawning rate increased more significantly (second set of trialsexperiment 1: 32\%) with a greater change in stocking density than was achieved with a smaller change (third set of trials - repeat 1: 25\%). Furthermore, it was found that repeated treatment of the same fish (third set of trials) caused an increase in the spawning rate from repeat 1 to repeat $3(25 \%, 26 \%$, and $39 \%)$. It was the combined effect of a photoperiod change after a 3 week period and a lower change of stocking density (second set of trialsexperiment 2) that yielded the highest spawning rate overall $(65 \%)$. The percentage of resulting hatchlings and swim-up fry was on average higher in all the experiments of the second and third set of trials than it was in the first one.

In the present study, the effect of environmental factors such as water temperature, stocking density and photoperiod on spawning in large groups of female O. niloticus breeders was systematically tested $(\mathrm{N}=674)$ for the first time. It was shown clearly that the spawning behaviour of female tilapia breeders can be manipulated in favour of scheduled production of spawn. Thus it is possible to produce a great number of eggs in a predefined period of time with a simple manipulation of stocking density, something relatively simple and fast to realise. If more time is available, a change in stocking density in combination with a 3 week photoperiod of $6 \mathrm{~L}: 18 \mathrm{D}$ is recommended. 
What now remains to be verified is whether the trigger that sets off spawning in the female after, for instance, a change in stocking density, is genetically determined. In that case, breeding lines capable of higher spawning rates could possibly be created through selection. 
Chapter 1

INTRODUCTION 
In the intensive aquaculture of economically important cyprinid and salmonid species, methods based on variation of environmental factors to control the reproduction of the broodstock are common practise. The development cycle of the fish gonads is influenced so as to benefit the planned production of eggs or sperm from spawners. Through changes in day length and water temperature the seasonal spawning behaviour is used to this end in cold water fish like trout and salmon.

The aquaculture of the warm water tilapia is also gaining in importance. Recently the world output of tilapia overtook that of salmonids in terms of quantity. Of all the several tilapia species which are cultivated, the Nile tilapia (Oreochromis niloticus) is the most economically important. The ease in cultivation, a rapid growth, a very palatable flesh and high resistance to disease, favour the farming of Nile tilapia. As a consequence research with this species is intensifying.

In order to perform selective breeding, gynogenesis, hybridisation or sex inversion, large amounts of ripe unfertilised eggs are necessary. Due to aseasonality and an individual development of the ovaries, it is difficult to harvest adequate quantities of Nile tilapia eggs. Furthermore no method has been developed yet which satisfyingly helps in controlling spawning in Nile tilapia for the purpose of egg production.

The aim of this study was the testing of variations in water temperature, stocking density and photoperiod in order to induce maximum spawning in a defined period of time. 


\section{Biology}

The order Perciformes is comprised of more than 100 different tilapia species (McAndrew 2000) worldwide and belongs to the family of the Cichlids (Trewavas 1983). Characteristic traits of this family are a compressed body and a long dorsal fin which consists of $16-17$ spines and 11 to 15 soft rays. The lateral line is interrupted at the height of the anal fin.

The most commonly cultivated species of the genus Oreochromis (O. niloticus, $O$. mossambicus, O. aureus) originated from Central and East Africa, while the Tilapia and Sarotherodon species originated from West Africa. More exactly the origins of Oreochromis niloticus are considered to be the White Nile in Uganda, from which this species spread to lakes and rivers in the North, South and Southwest of Africa (Philippart \& Ruwet 1982). The Nile tilapia population maintained at the Institute of Animal Husbandry and Genetics are derived from Lake Manzala in Egypt.

Tilapia species are classified according to their brooding behaviour and feeding habits (LoweMcConnell 1959).

\section{Substrate spawners}

Tilapiines of the genus Tilapia are monogamous, biparental spawners which lay eggs on bottom substrates in a nest dug by the male and female. The eggs and fry are guarded by the parents but are not taken in their mouth for protection. After hatching the larvae are made to adhere to prepared substrate until they develop into fry.

\section{Biparental and paternal mouthbrooders}

In the genus Sarotherodon, either both parents or only the male incubates the eggs in their buccal cavity. The brood leave the mouth when they are able to swim on their own. Sarotherodon species lay larger and fewer eggs than Tilapia species. The brooding parent through movement of its jaw maintains the eggs in movement for optimal incubation.

\section{Maternal mouthbrooders}

Species of the genus Oreochromis also hold eggs in their mouth, but unlike in Sarotherodon, solely the female performs this type of incubation. In the Oreochromis genus, reproduction occurs as arena spawning. Each male establishes a territory and builds a round nest in it. The 
male defends his territory from other males while at the same time attracting females to the nest by courtship displays. Courtship colours range from red to black. Once a female enters the nest, she lays eggs which are fertilised by the male. Immediately after fertilisation the female picks up the eggs in her mouth. Each female can have batches of her eggs fertilised by different males, just as each male can fertilise eggs from different females. Oreochromis species lay larger and less eggs than Tilapia or Sarotherodon species. After 4-5 days, depending on the temperature, the eggs hatch in the mouth of the female where they remain until the fry are able to swim.

\section{Production of tilapia}

The production of cultivated tilapias has increased exponentially during the last 20 years (Figure 1). In the year 2000, a global output of 1 million tonnes was recorded for the first time and in 2005, it passed 2 million tonnes (FAO, 2007). This tendency is expected to be maintained in the future and the outlook for farmers is very good. Moreover global tilapia production is dominated by Nile tilapia. From 1995 onwards, more than $70 \%$ of all produced tilapia was Nile tilapia (FAO, 2007).

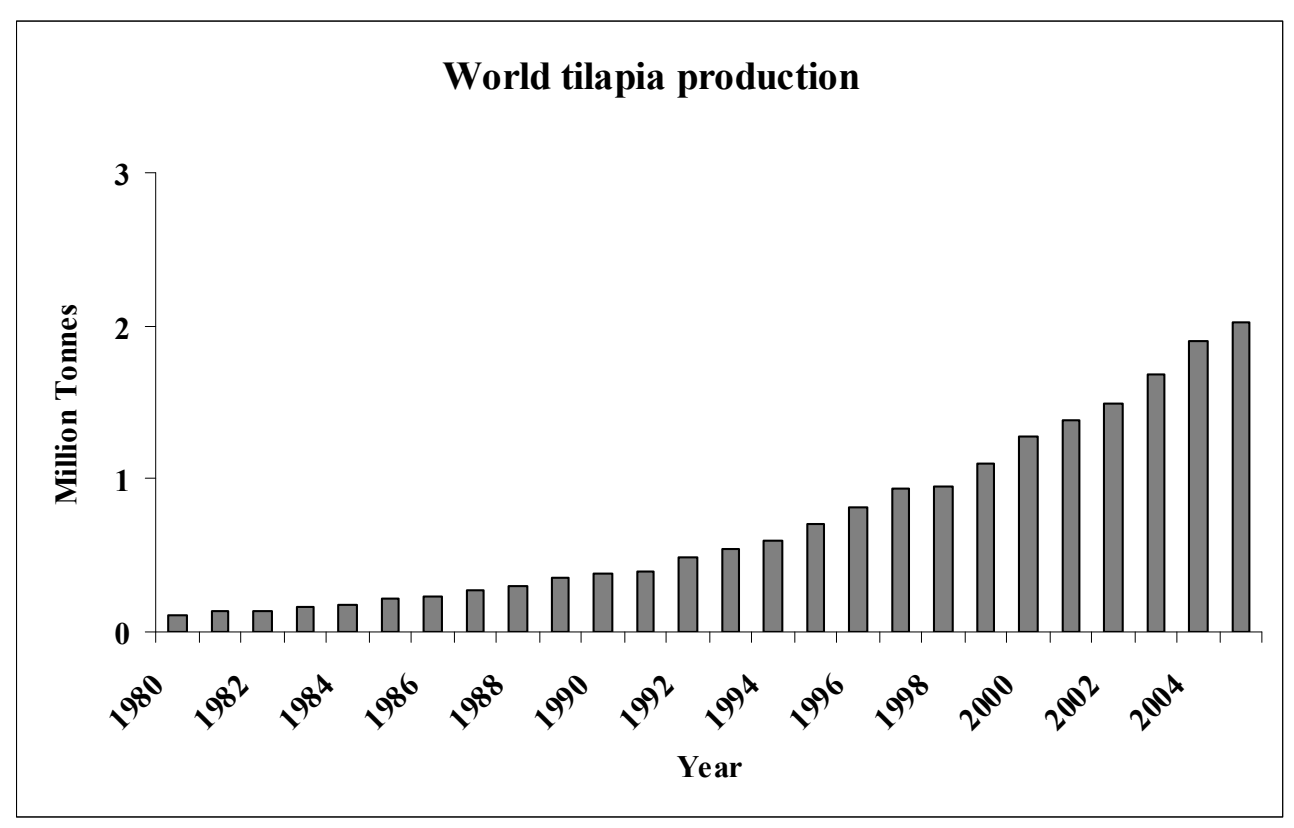

Figure 1: World production of tilapia from 1980 to 2005 in million tonnes (FAO 2007) 


\section{Physiology of reproduction}

\section{Ovary and testes}

The sexual differentiation of Tilapia gonads occurs around 15 to 30 days after fecundation, (Nakamura \& Takahashi 1973; Yoshikawa \& Oguri 1978). Depending on environmental conditions, sexual maturity can already be reached after 2-3 months.

\section{The ovary}

In Teleosteii, the growth of ovaries can be subdivided into 6 stages: oogenesis, primary ooctyte growth, corticular alveolar stage, vitellogenesis, maturation and ovulation (Tyler \& Sumpter 1996). At the beginning of oogenesis, the small oocytes consist of an ooplasm surrounded by a zona radiate. Groups of oocytes prevail in nests contained by a single layer of cells which will develop to form the follicle envelope. DNA is replicated and the oocyte goes through the first stages of meiosis. During the primary oocyte growth, the oocytes are transformed into primary oocytes. Each primary oocyte is surrounded by a single layer of follicle cells and intracellular organelles multiply in the cell. Towards the end of this phase a vitelline envelope develops under the follicle epithelium. Reduction division is halted in the first prophase of meiosis. The oocyte develops further in the corticular alveolar stage and yolk vesicles abound in large numbers in the ooplasma, containing glycoproteins, carbohydrates and lipids synthesised in the cell. During cortical alveolus stage, the germinal vesicle continues to enlarge with numerous nucleoli. Throughout vitellogenesis, a marked growth of the oocyte is observed due to accumulation of yolk. The yolk-precursor vitellogenin, a lipophosphoprotein derived from the liver, is controlled through the action of oestrogen. The highly irregular germinal vesicle migrates from the centre to the periphery of the oocyte. During oocyte maturation, oocytes continue to enlarge due to hydration and the first stages of meiosis are resumed, proceeding to the second meiotic metaphase where the chromosomes arrest. At this time the oocyte has become a follicle, an oocyte with the distinct surrounding tissues (the granulosa, theca and surface epithelium). At ovulation, the mature oocyte is released from its follicle wall enclosure in the ovary. Ovulation is the release of a mature oocyte from its follicle wall enclosure in the ovary. The oocyte separates from the granulosa layer and the follicle wall ruptures to expulse the oocyte. Meiosis is completed at fertilisation with the penetration of the egg by sperm.

Distinctive features of $O$. tilapia ovaries at different stages of maturation have been described (Babiker 1986; Tacon, Ndiaye, Cauty, Le Menn \& Jalabert 1996). However, the most 
accurate description is that of Tilapia zillii (Coward \& Bromage 1998). Size range and oocyte development are given in table 1.

Table 1: Development stages of oocytes in Tilapia zillii (Coward \& Bromage 1998)

\begin{tabular}{|c|c|c|}
\hline Oocyte stage & $\begin{array}{l}\text { Size range } \\
\quad(\mu \mathrm{m}) \\
(\mathrm{mean} \pm \mathrm{SD})\end{array}$ & Appearance \\
\hline$\overline{\text { Oogonia }}$ & $\begin{array}{c}4-6 \\
(5 \pm 0 \cdot 1)\end{array}$ & $\begin{array}{l}\text { Approx. spherical. Contain little cytoplasm. Often found in } \\
\text { nests in germinal tissue. }\end{array}$ \\
\hline $\begin{array}{l}\text { Stage } 1 \\
\text { (chromatin nucleolar stage) }\end{array}$ & $\begin{array}{c}7-11 \\
(9 \pm 0 \cdot 3)\end{array}$ & $\begin{array}{l}\text { Often close to oogonia. Similar to oogonia in appearance. } \\
\text { Conspicuous nucleus containing chromatin strands }\end{array}$ \\
\hline $\begin{array}{l}\text { Stage } 2 \\
\text { (early perinucleolar stage) }\end{array}$ & $\begin{array}{l}36-240 \\
(97 \pm 1 \cdot 1)\end{array}$ & $\begin{array}{l}\text { Highly basophilic cytoplasm staining dark red/purple. } \\
\text { Localized areas of intense basophilia often close to nucleus or } \\
\text { oocyte periphery. }\end{array}$ \\
\hline $\begin{array}{l}\text { Stage } 3 \\
\text { (late perinucleolar stage) }\end{array}$ & $\begin{array}{l}122-342 \\
(214 \pm 1 \cdot 4)\end{array}$ & $\begin{array}{l}\text { Less basophilic than stage } 2 \text { - therefore stains lighter (pale } \\
\text { pink). Central nucleus contains several nucleoli and chromatin } \\
\text { strands. Developing follicular layer. }\end{array}$ \\
\hline $\begin{array}{l}\text { Stage } 4 \\
\text { (cortical alveolar stage) }\end{array}$ & $\begin{array}{l}219-326 \\
(280 \pm 3 \cdot 2)\end{array}$ & $\begin{array}{l}\text { Ooplasm highly acidophilic_-stains light pink. Numerous } \\
\text { vesicles close to oocyte periphery. Nucleoli and chromatin } \\
\text { persist in central nucleus. }\end{array}$ \\
\hline $\begin{array}{l}\text { Stage } 5 \\
\text { (vitellogenesis) }\end{array}$ & $\begin{array}{l}224-658 \\
(395 \pm 3 \cdot 9)\end{array}$ & $\begin{array}{l}\text { Appearance of small yolk granules at oocyte periphery. } \\
\text { Numerous vesicles/vacuoles dispersed throughout oocyte. } \\
\text { Yolk granules stain dark pink. Follicular layer becomes much } \\
\text { more developed. Nucleus still central. }\end{array}$ \\
\hline $\begin{array}{l}\text { Stage } 6 \\
\text { (maturation) }\end{array}$ & $\begin{array}{l}428-1416 \\
(964 \pm 6 \cdot 9)\end{array}$ & $\begin{array}{l}\text { Yolk granules accumulate into large yolk globules. Many } \\
\text { apparently empty large vacuoles found especially towards } \\
\text { oocyte periphery. Yolk globules distributed throughout oocyte. } \\
\text { Nucleus remains central. Particularly prominent follicular } \\
\text { layer. }\end{array}$ \\
\hline $\begin{array}{l}\text { Stage } 7 \\
\text { (germinal vesicle migration) }\end{array}$ & $\begin{array}{l}428-1416 \\
(964 \pm 6 \cdot 9)\end{array}$ & $\begin{array}{l}\text { As stage } 6 \text { but germinal vesicle seen to migrate towards } \\
\text { periphery of oocyte (animal pole) }\end{array}$ \\
\hline
\end{tabular}

Oocyte development can generally be called synchronous or asynchronous (Scott 1987). Tilapias are asynchronous (Yaron, Gur, Melamed, Rosenfeld, Elizur \& Levavi-Sivan 2003). However, depending on environmental factors, a broad spectrum might possibly exist between both extremes (Msiska 2002). Furthermore, it is also not clear from which oocyte 
growth stage the next oocytes are recruited for developing into mature oocytes (Jalabert \& Zohar 1982). One oocyte generation in the vitellogenic stage might occur at the same time as a generation of mature oocytes (Yaron et al. 2003). In Oreochromis niloticus and Tilapia zillii it was shown that each new group of maturing oocytes arose from a pool of pre-vitellogenetic eggs (Babiker 1986; Coward \& Bromage 1998). In contrast, with Oreochromis mossambicus females, it was shown that oocytes were already in the vitellogenesis stage when recruited for developing in mature oocytes (Peters 1983). However, this difference in oocyte recruitment could be specific to the species or could be influenced by parental care of fry or social interactions between females (Jalabert \& Zohar 1982; Tacon et al. 1996).

\section{The testes}

Spermatogenesis consists of three major stages; mitotic proliferation, meiosis and spermiogenesis (Schulz \& Miura 2002). Through successive mitotic divisions, spermatogonial stem cells are transformed into spermatogonia which are at all times in contact with Sertoli cells. These cells nurse the spermatogonia and together build numerous cysts of cells throughout the testes. The spermatogonia undergo a number of mitotic divisions before they divide by meiosis to produce four spermatids which transform into flagellated spermatozoa. In the tropics, Oreochromis niloticus and Oreochromis aureus are known to have a continuous sperm production all year round (Lowe-McConnell 1959; Hyder 1972).

\section{Hormonal regulation}

Two distinct gonadotropins have been found in a number of teleost fish and in tilapia (Suzuki, Kawauchi \& Nagahama 1988; Bogomolnaya, Yaron, Hilge, Graesslin \& Lichtenberg 1989; Rosenfeld, Levavi-Sivan, Gur, Melamed, Meiri, Yaron \& Elizur 2001). These are homologous to the mammalian follicle-stimulating hormone (FSH) and luteinizing hormone (LH). These gonadotropins contain an $\alpha$-subunit which is common to both FSH and LH and a $\beta$-subunit which is unique to each gonatropin (Rosenfeld et al. 2001). In tilapia, the presence of LH $\beta$ and FSH $\beta$ have been demonstrated (Rosenfeld, Levavi-Sivan, Levavi-Sivan, Melamed, Yaron \& Elizur 1997). However, in fish more is known on LH than on FSH (Van der Kraak, Chang \& M. 1998). 


\section{The hypothalamus and gonadotropin releasing hormone}

The gonadotropin releasing hormone $(\mathrm{GnRH})$ plays a primary role in reproduction of teleosts due to its regulatory effect on the secretion of the gonadotropins FSH and LH (Van der Kraak et al. 1998). Regulation of LH involves a complex relationship between peptides and steroid hormones (Figure 2).

\section{Stimulatory factors}

Besides GnRH which has the strongest effect by directly stimulating the gonadotroph to produce LH, serotonin (5-HT), neuropeptide Y (NPY), $\gamma$-aminobutyric acid (GABA), and norepinephrine (NE) also encourage LH production (Figure 2).

\section{Inhibitory factors}

Dopamine (DA) is the most important inhibiting factor for GnRH-induced LH in cyprinids and in tilapia (Levavi-Sivan, Biran \& Fireman 2006). $\mathrm{D}_{2}$ receptors on gonadotropin producing cells of teleosts mediate the dopaminergetic inhibition of LH release (Yaron et al. 2003).

\section{Ovarian steroid feedback}

Depending on the reproductive phase, testosterone and oestradiol exert either a positive or a negative feedback control on the secretion of LH (Peter \& Yu 1997; Van der Kraak et al. 1998). Experiments with teleosts that had reached sexual maturity indicated a negative feedback action of oestradiol and testosterone on LH release (Trudeau \& Peter 1995). The effect of these sex steroids is thought to be indirectly exerted through inhibition of $\gamma$ aminobutyric acid which results in a decreased stimulation of GnRH release (Trudeau \& Peter 1995). In sexually immature fish, on the other hand, oestradiol and testosterone were shown to exert a positive feedback on LH secretion (Peter, Trudeau, Sloley, Peng \& Nahorniak 1991). These steroids act on the gonadotroph at the pituitary level (Van der Kraak et al. 1998) or through inhibition of dopamine in the brain which promotes GnRH secretion (Peter \& Yu 1997). 
Figure 2: Control of LH secretion in teleosts.

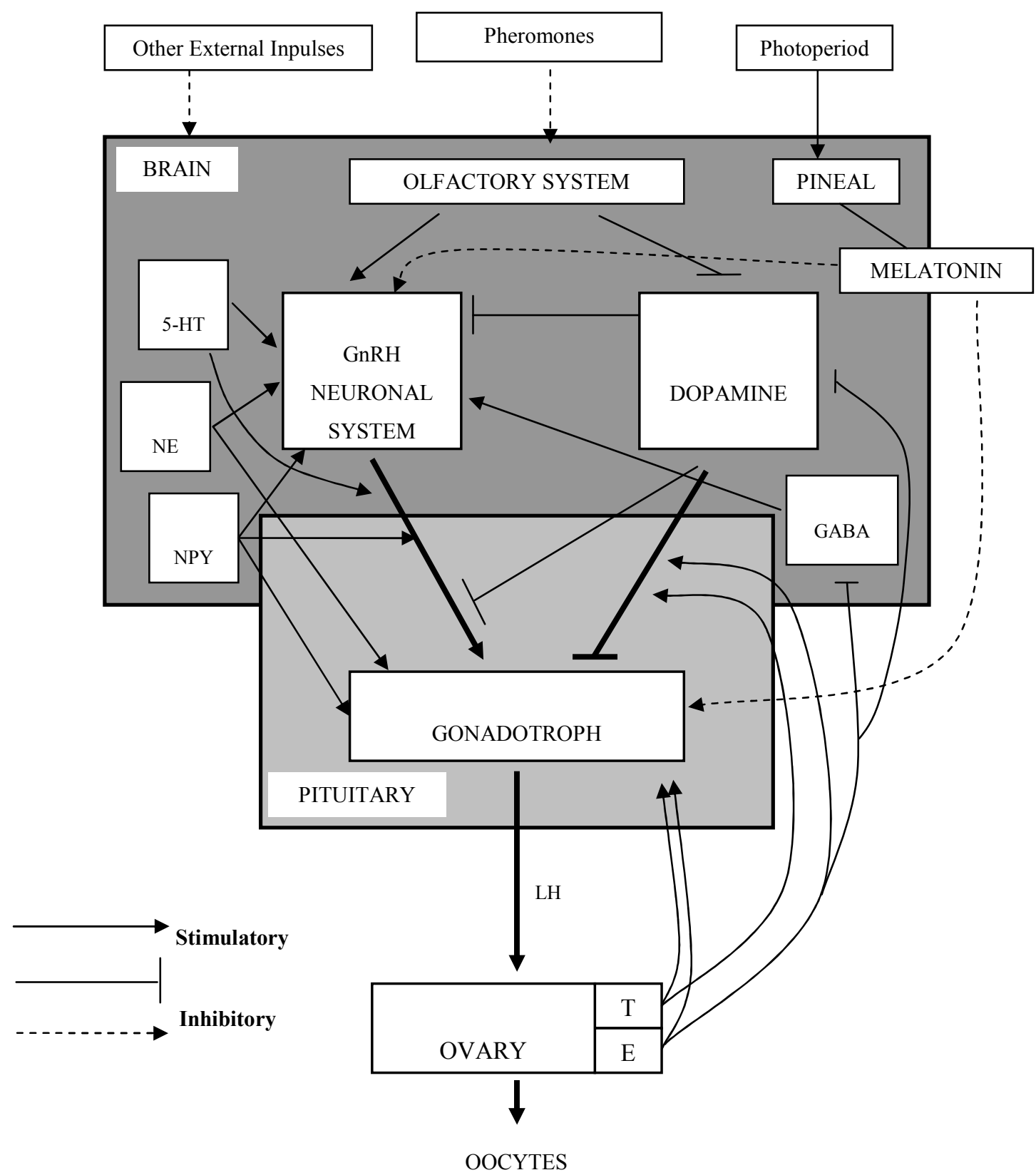

Abbreviations: E, oestradiol; GABA, $\gamma$-aminobutyric acid; GnRH, gonadotrophin-releasing hormone; NPY, neuropeptide Y; NE, norepinephrine; 5-HT, serotonin; T, testosterone; LH, luteinizing hormone. Adapted from Peter et al. (1997) and Van der Kraak et al. (1998) 


\section{Endocrine regulation of vitellogenesis and ovulation}

In tilapia, the cells of the proximal pars distalis region of the pituitary are differentiated in distinct regions for the production of LH and FSH (Melamed, Rosenfeld, Elizur \& Yaron 1998). In salmonids, it is well documented that FSH is the major gonadotropin in the blood of vitellogenic females but decreases in concentration at ovulation, whereas LH levels increase during ovarian maturation until the fish spawns (Nagahama, Yoshikuni, Yamashita \& Tanaka 1995). The mode of gonadotropin action has not yet been successfully demonstrated in tilapia, but it has been shown that blood-plasma levels of LH peak during ovulation (Bogomolnaya et al. 1989). In O. niloticus, a fivefold increase in LH has been demonstrated during spawning (Rothbard, Ofir, Levavi-Sivan \& Yaron 1991).

Figure 3A outlines the effect of FSH on the ovary of a teleost (Yaron et al. 2003). During vitellogenesis, GnRH is released from the hypothalamus which induces secretion of FSH in the pituitary. FSH causes the ovarian follicle to produce oestrogen, which stimulates the liver to generate vitellogenin. The oocytes store the vitellogenin as yolk during their development. Figure 3B illustrates the action of LH on the oocyte of a cyprinid (Yaron et al. 2003). Stimulation of the pituitary by GnRH and inhibition by dopamine (DA) brings about LH secretion. LH causes post-vitellogenic oocytes to secrete a steroid (17 $2,20 \beta$-dihydroxy-4-pregnen-3-one) which promotes the production of the maturation-inducing factor (MPF) inducing ovulation.
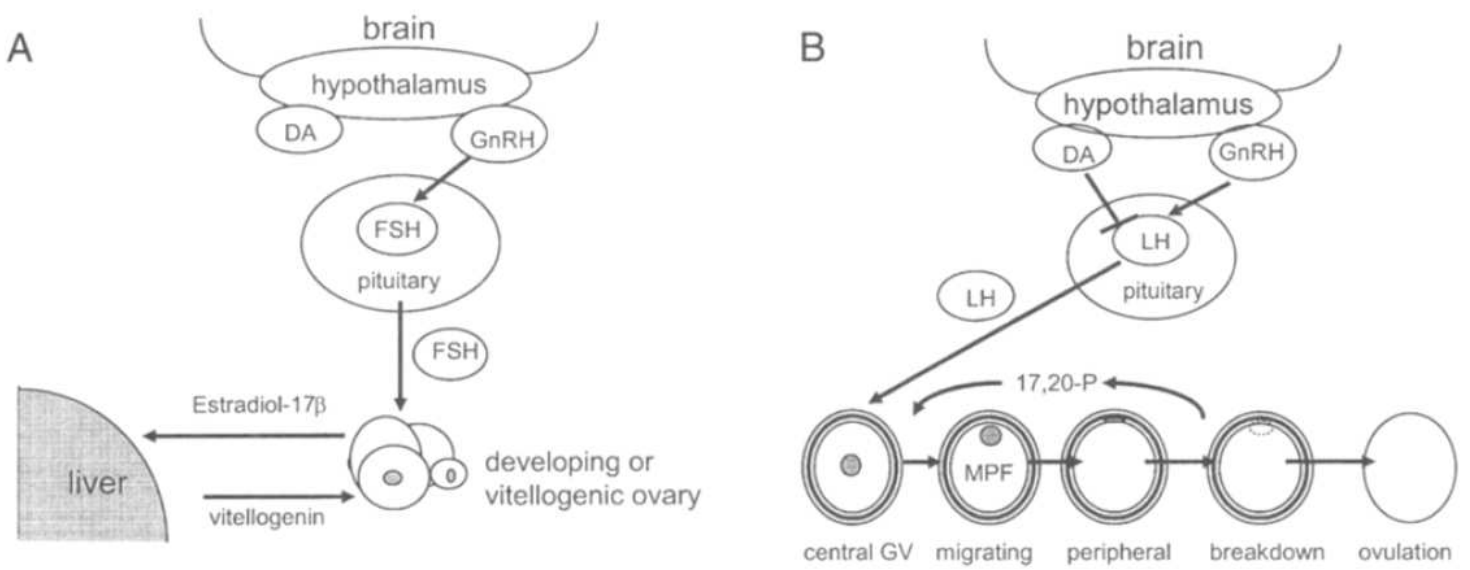

Figure 3: (A) the endocrine regulation of vitellogenesis. (B) the endocrine regulation to ovulation (Yaron et al. 2003). 


\section{External impulses in reproduction}

In nature, fish experience a constantly changing environment. This has a direct consequence on the regulation of reproduction. It has been proposed that a complex interplay between environmental factors and endogenous factors assure that the fry are able to grow in an environment which is least detrimental to their development (Bromage, Porter \& Randall 2001). The following environmental factors are known to cue reproduction in teleosts:

\section{Photoperiod}

The effect of the daily light duration has been extensively researched in salmonids and is considered the most important external impulse for influencing the spawning in such fish as Atlantic salmon (Salmo salar), rainbow trout (Oncorhynchus mykiss), Atlantic cod (Gadus morua), sea bream (Sparus aurata) and sea bass (Dicentrarchus labrax) (Boeuf \& Le Bail 1999; Bromage et al. 2001; Kissil, Lupatsch, Elizur \& Zohar 2001; Rodriguez, Zanuy \& Carrillo 2001; Van der Meeren \& Ivannikov 2006). For example, spawning in rainbow trout can be advanced by using long light hours (January to May) followed by an abrupt change to short hours, while short light hours all year round or during the first 6 months of the year retard spawning (Bromage, Elliott, Springate \& Whitehead 1984; Wildenhayn 2002). Although the effect of photoperiod is better understood in salmonids, it is thought to play an equally important role in fish of warmer climates (Lam, Munro \& of Fish 1987. pp. 279-288. Edited by Memorial University of Newfoundland 1987; Bromage et al. 2001). Short light periods, consisting of 6 hours of light and 6 hours of darkness (6L:6D) stopped spawning in O. niloticus after 3 to 4 spawning cycles (Biswas, Morita, Yoshizaki, Maita \& Takeuchi 2005), whereas longer day lengths (18L:6D) increased the fecundity (7.2 eggs $\mathrm{g}^{-1}$ body weight) of the spawners significantly (Campos-Mendoza, McAndrew, Coward \& Bromage 2004). Besides light duration, light intensity seems to affect reproduction. Using combinations of light intensity (2500 lux, 500 lux) and of photoperiod (18L:6D, 15L:9D, and 12L:12D), Ridha and Cruz (2000) observed the highest fecundity at 2500 lux and 18L:6D (4.9 eggs g $^{-1}$ body weight). 
In terms of its effect on the brain, photoperiod is the best understood of external factor. In the absence of light, the pineal organ produces melatonin (Fig. 2). In several teleosts, higher plasma melatonin levels were measured during the nocturnal period, which then fell to minimum levels during the light period (Bromage et al. 2001). Furthermore, photoperiod has a definite effect on the brain-pituitary-gonadal axis of salmonids; changes in photoperiod alter the GnRH, LH and FSH levels (Amano, Okumoto, Kitamura, Ikuta, Suzuki \& Aida 1994; Davies, Bromage \& Swanson 1999). Though melatonin is known to influence GnRH, LH and FSH production, its mode of action in the brain has not been fully determined (Bromage et al. 2001).

\section{Water temperature}

Temperature is, after photoperiod, one of the major seasonal cues in reproduction. In cyprinids, a rising water temperatures accelerates ovarian recrudescence and is probably the determinant factor in inducing final oocyte maturation and ovulation (Stacey 1984). Temperature plays also an important role in combination with photoperiod; cool or warm autumn temperatures respectively advance or delay spawning in Atlantic salmon (Taranger \& Hansen 1993). Suboptimal temperatures also inhibit the development of gonads. O. aureus ovaries and testes regress at $17^{\circ} \mathrm{C}$ (Terkatin-Shimony, Ilan, Yaron \& Johnson 1980), O. niloticus produces sperm above a temperature of $24^{\circ} \mathrm{C}$ but spermatogenesis is arrested at $20^{\circ} \mathrm{C}$ (Vilela, Silva, Peixoto, Godinho \& França 2003). Furthermore, studies with $O$. karongae indicate a significant effect of the maximum water temperature on the fry and fingerling production (Msiska \& Costa-Pierce 1997). Water temperature changes have been tested as a method of increasing spawning in Nile tilapia (Srisakultiew \& Wee 1988). In these experiments, short (6-24 hours) and long term $\left(1,2,3\right.$ weeks) reduced water temperatures of $22 \pm 1.5^{\circ} \mathrm{C}$ were tested. The long term treatment was unsuccessful while the short term treatment induced 10-25\% more females to spawn than in the control.

In O. mossambicus, LH and LSH levels increased with rising water temperature (Cornish, Smit \& Campbell 1997). Besides its direct effect on gonadal development, temperature is thought to influence reproduction through the metabolism rate (Van Der Kraak \& Pankhurst 1997). The build-up and clearance rates of hormones change with the metabolism rate and this influences endocrine processes (Van Der Kraak \& 
Pankhurst 1997). Melatonin is also affected by temperature; lower temperatures lower the melatonin levels in Atlantic salmon during the nocturnal phase while higher temperatures raise it (Randall, Bromage, Thorpe, Miles \& Muir 1995).

\section{Stocking density}

The way females are kept together influences their reproduction; female Nile tilapia stocked in single compartments seemed to spawn more often than those which were group stocked (Stamer 2001). Generally high stocking densities lower reproduction in tilapiines (Paessun \& Allison 1984; Turner, Phirl \& Cawthraw 1989). Other experiments demonstrated that, at the lowest stocking density tested ( 4 fish $\mathrm{m}^{-2}$ ), the females had a significantly higher egg output (measured in egg output per year) than at 8 and 12 fish $\mathrm{m}^{-2}$ (Ridha \& Cruz 1999). A possible explanation is that when more females come together in a group, they take up a schooling behaviour which dampens their spawning activity (Balarin, Haller \& Armitage 1986). Furthermore, the strong hierarchy which prevails in denser fish groups can inhibit reproduction (Fishelson 1983; Turner et al. 1989). When Tilapia zillii females were moved from crowded holding tanks (stocking density $=\sim 20 \mathrm{~kg} \mathrm{~m}^{-3}$ ) into single compartments, a relatively high spawning incidence (55\% of females spawned) was observed during a period of 10 days following transfer (Coward, Bromage \& Little 1998). In the same experiments, testosterone and oestradiol levels peaked after the females were transferred to single compartments, while crowded fish had lower and fairly constant levels of both steroids.

\section{Pheromones}

The goldfish (Carassius auratus) has been extensively studied with regard to the role of olfactory signals in reproduction. The sex hormone 17 $2,20 \beta$-dihydroxy-4-pregnen-3one $(17 \alpha, 20 \beta-P)$ excreted via the urine by an ovulatory female increases the rate of ovulation in other females, while stimulating sperm production in the male testis (Stacey, Sorensen, Van der Kraak \& Dulka 1989). In African catfish, (Clarias gariepinus) and in zebrafish, (Brachydanio rerio) a primer pheromone (steroid glucuronide) released by the males in the water is thought to induce ovulation in the females (Van den Hurk, Schoonen, Van Zoelen \& Lambert 1987; Van Weerd, Sukkel, Bin Awang Kechik, Bongers \& Richter 1990). In tilapiines, an increase in the courtship 
activity of $O$. niloticus males towards females injected with $17 \alpha, 20 \beta-\mathrm{P}$ was observed (De Souza, Lucion \& Wassermann 1998).

\section{Sex ratio}

The ratio of males to females is also an important determinant in reproduction of Nile tilapia. Increasing the proportion of females to males decreases the total fry output (Hughes \& Behrends 1983), while sex ratios of 1:2 and 1:3 were found to be best for fry output (Siddiqui \& Al-Harbi 1997).

\section{Diet}

As proteins and lipids are key components of egg yolk, they are expected to play a major role in reproduction (Gunasekera, Shim \& Lam 1995). O. niloticus females fed 20 and $35 \%$ protein diets had a higher output of eggs per spawn than those fed $10 \%$ (Gunasekera, Shim \& Lam 1996). Furthermore, higher percentages of Stage 4 oocytes were counted for females fed a $35 \%$ protein diet than for those fed a $10 \%$ protein diet, while ovarian recrudescence was slower for the latter (Gunasekera \& Lam 1997). Furthermore a change of photoperiod in combination with an increase of $35 \%$ to $50 \%$ in protein content of the diet induced $72 \%$ of females to spawn in a 7 day period (Puckhaber 1992).

The lipid source has also been shown to have an effect on reproduction; the number of females that spawned, spawning frequency, number of fry per spawning, and total fry production were shown to be affected by the lipid source (fish oil, corn oil, soybean oil, and coconut oil-based cooking oil) supplemented with the diet (Santiago \& Reyes 1993; El-Sayed, Mansour \& Ezzat 2005). A combination of photoperiod with a change

\section{Others}

Type and access to substrate is believed to influence spawning of Tilapia zillii (Bruton \& Gophen 1992), while lunar cycles can affect the spawning of Tilapia mariae (Schwanck 1987). Water hardness and water-salinity were also shown to affect the spawning rates of O. niloticus females (Stamer 2001). 


\section{Scope of the thesis}

The main scope of this thesis was testing the applicability of the environmental factors (water temperature, stocking density and photoperiod) in inducing high spawning rates in a short period on Nile tilapia spawners. Besides the number of spawns recorded, egg quality and fertility were also assessed and compared.

In chapter 2, the factor water temperature was addressed. In 3 experiments, the effect of reducing the water temperature from $28^{\circ} \mathrm{C}$ to $22^{\circ} \mathrm{C}$ for a 7-day, 14-day and 28-day period was analysed. Each experiment was run with its own control where the water temperature was kept at $28^{\circ} \mathrm{C}$ during the whole experiment; all conditions that prevailed were otherwise identical in the control and in the treatment group. The spawning rates were measured at weekly intervals over the whole experiment (acclimatisation phase, treatment phase, spawning phase). Furthermore, the spawning phase was subdivided into a three day and seven day period, where spawning rates and the reproductive parameters (number of eggs per female, relative fecundity, hatching and swim-up fry rates) were compared.

The factors stocking density and photoperiod were tested in chapters 3 and 4 . In the first experiment, Nile tilapia spawners were kept together in one large holding tank for one week. They were then moved to smaller aquaria where they were stocked individually for another week. In the process the stocking density was reduced in a ratio of $7: 1$. In experiment 2, the spawners were kept together in a holding tank for 21 day and 28 day periods with a photoperiod of 6 hours of light and 18 hours of darkness (6L:18D). Subsequently, the stocking density was reduced as in experiment 2 in a ratio of $4: 1$. The last experiment in chapter 4 was similar to the first experiment of chapter 3 , except that the procedure was then repeated three times (repeat 1,2 and 3) with the same spawners and the stocking density was reduced in a ratio of $4: 1$. As a control, spawners were also kept together in the holding tank for one week but were stocked in groups of 12 females in the small aquaria. The stocking density was reduced in a ratio of $3: 1$. In all experiments it was not possible to observe and strip the females when they were kept together in the fibre-glass holding tank, this was possible only after their transfer to 
glass aquaria. The spawning rates and the reproductive parameters were measured over a five day spawning phase. Furthermore, during this phase, the daily spawning rates were also calculated.

The last chapter concludes this thesis with the general discussion. The following factors: water temperature, stocking density and photoperiod, are discussed in chapter 5. To compare these factors, the spawning phase of the temperature treatments was summarised over a 5 day period as in chapter 3 instead of a 7 day period (chapter 3 ). Furthermore the daily spawning rates of all factors were calculated for this same period. 


\section{References}

Amano M, Okumoto N, Kitamura S, Ikuta K, Suzuki Y, Aida K (1994) Salmon Gonadotropin-Releasing Hormone and Gonadotropin Are Involved in Precocious Maturation Induced by Photoperiod Manipulation in Underyearling Male Masu Salmon, Oncorhynchus masou. General and Comparative Endocrinology, 95, 368-373.

Babiker MM (1986) Spawning periodicity and annual breeding seasons of Tilapia nilotica (L.) in the White Nile. Hydrobiologia, 135, 71-79.

Balarin JD, Haller RD, Armitage AT (1986) Research on Intensive Culture of Tilapia in Tanks. In: Aquaculture research in the Africa region: proceedings of the African Seminar on Aquaculture, organised by the International Foundation for Science (IFS), Stockholm (ed Huisman EA). Pudoc, 1986, Wageningen, pp. 206-216.

Biswas AK, Morita T, Yoshizaki G, Maita M, Takeuchi T (2005) Control of reproduction in Nile tilapia Oreochromis niloticus (L.) by photoperiod manipulation. Aquaculture, 243, 229-239.

Boeuf G, Le Bail P-Y (1999) Does light have an influence on fish growth? Aquaculture, 177, 129-152.

Bogomolnaya A, Yaron Z, Hilge V, Graesslin D, Lichtenberg V (1989) Isolation and radioimmunoassay of a steroidogenic gonadotropin of tilapia. Isr. J. AquacultBamidgeh, 41, 123-136.

Bromage N, Porter M, Randall C (2001) The environmental regulation of maturation in farmed finfish with special reference to the role of photoperiod and melatonin. Aquaculture, 197, 63-98.

Bromage NR, Elliott JAK, Springate JRC, Whitehead C (1984) The effects of constant photoperiods on the timing of spawning in the rainbow trout. Aquaculture, 43, 213-223.

Bruton MN, Gophen M (1992) The effect of environmental factors on the nesting and courtship behaviour of Tilapia zillii in Lake Kinneret (Israel). Hydrobiology, $171-178$.

Campos-Mendoza A, McAndrew BJ, Coward K, Bromage N (2004) Reproductive response of Nile tilapia (Oreochromis niloticus) to photoperiodic manipulation; effects on spawning periodicity, fecundity and egg size. Aquaculture, 231, 299314.

Cornish DA, Smit GL, Campbell IM (1997) Seasonal fluctuations in gonadotropin levels in the plasma and gonads of male and female tilapia, Oreochromis mossambicus. . Water South Africa, 23, 263-270.

Coward K, Bromage NR (1998) Histological classification of oocyte growth and the dynamics of ovarian recrudescence in Tilapia zillii. Journal of Fish Biology, 53, 285-302.

Coward K, Bromage NR, Little DC (1998) Inhibition of spawning and associated suppression of sex steroid levels during confinement in the substrate-spawning Tilapia zillii. Journal of Fish Biology, 52, 152-165.

Davies B, Bromage N, Swanson P (1999) The Brain-Pituitary-Gonadal Axis of Female Rainbow Trout Oncorhynchus mykiss: Effects of Photoperiod Manipulation1. General and Comparative Endocrinology, 115, 155-166. 
De Souza SMG, Lucion AB, Wassermann GF (1998) Influence of 17[alpha],20[beta]dihydroxy-4-pregnen-3-one Injected into a Post-ovulatory Female on the Reproductive Behavior of Male Nile Tilapia (Oreochromis niloticus). Comparative Biochemistry and Physiology - Part A: Molecular \& Integrative Physiology, 119, 759-763.

El-Sayed A-FM, Mansour CR, Ezzat AA (2005) Effects of dietary lipid source on spawning performance of Nile tilapia (Oreochromis niloticus) broodstock reared at different water salinities. Aquaculture, 248, 187-196.

FAO (2007) Food and Agriculture Organisation of the United Nations. Aquaculture Production Statistics 1980 - 2005.

Fishelson L (1983) Social behaviour of adult tilapia fish in nature and in captivity In: Proceedings of the International Symposium on Tilapia in Aquaculture (eds Fishelson L, Yaron Z). Tel Aviv University Press, Tel Aviv, Israel, pp. 48-58.

Gunasekera RM, Lam TJ (1997) Influence of dietary protein level on ovarian recrudescence in Nile tilapia, Oreochromis niloticus (L.). Aquaculture, 149, 5769.

Gunasekera RM, Shim KF, Lam TJ (1995) Effect of dietary protein level on puberty, oocyte growth and egg chemical composition in the tilapia, Oreochromis niloticus (L.). Aquaculture, 134, 169-183.

Gunasekera RM, Shim KF, Lam TJ (1996) Effect of dietary protein level on spawning performance and amino acid composition of eggs of Nile tilapia, Oreochromis niloticus. Aquaculture, 146, 121-134.

Hughes DG, Behrends LL (1983) Mass production of Tilapia nilotica seed in suspended net enclosures. In: International Symposium of Tilapia in Aquaculture. (eds Fishelson L, Yaron Z). Tel Aviv University, Tel Aviv, Israel, pp. 394-401.

Hyder M (1972) Endocrine regulation of reproduction in Tilapia. General and Comparative Endocrinology, 3, 729-740.

Jalabert B, Zohar Y (1982) Reproductive physiology in cichlid fishes, with particular references to Tilapia and Sarotherodon. In: The Biology and Culture of Tilapia. ICLARM conference proceedings 7 (eds Pullin RSV, Lowe-McConnell RH). ICLARM, Manila, pp. 129-140.

Kissil GW, Lupatsch I, Elizur A, Zohar Y (2001) Long photoperiod delayed spawning and increased somatic growth in gilthead seabream (Sparus aurata). Aquaculture, 200, 363-379.

Lam TJ, Munro ADIRP, of Fish 1987. pp. 279-288. Edited by Memorial University of Newfoundland SJs (1987) Environmental control of reproduction in teleosts: An overview. In: Third International Symposium on the Reproductive Physiology of Fish. (eds Idler DR, Crim LW, Walsh JM). Memorial University of Newfoundland, St. John's, pp. 279-288.

Levavi-Sivan B, Biran J, Fireman E (2006) Sex Steroids Are Involved in the Regulation of Gonadotropin-Releasing Hormone and Dopamine D2 Receptors in Female Tilapia Pituitary. Biol Reprod, 75, 642-650.

Lowe-McConnell RH (1959) Breeding behaviour patterns and ecological differences between Tilapia species and their significance for evolution within the genus Tilapia (Pisces: Cichlidae). Proc. Zool., 132, 1-30. 
McAndrew BJ (2000) Evolution, phylogenetic relationships and biogeography. In: Tilapias: Biology and Exploitation. (ed. by Beweridge MCM, McAndrew BJ). Kluwer Academic Publishers, pp. 1-32.

Melamed P, Rosenfeld H, Elizur A, Yaron Z (1998) Endocrine regulation of gonadotropin and growth hormone gene transcription in fish. Comparative Biochemistry and Physiology Part C: Pharmacology, Toxicology and Endocrinology, 119, 325-338.

Msiska OV (2002) The histology of mature gonads of Oreochromis (Nyasalapia) karongae (Trewavas). African Journal of Ecology, 40, 164-171.

Msiska OV, Costa-Pierce BA (1997) Factors influencing the spawning success of Oreochromis karongae (Trewavas) in ponds. Aquaculture Research, 28, 87-99.

Nagahama Y, Yoshikuni M, Yamashita M, Tanaka M (1995) Regulation of oocyte maturation in fish. In: Molecular Endocrinology of Fish (ed. by Sherwood NM, Hew CL). Academic Press, New York, pp. 393-439.

Nakamura M, Takahashi H (1973) Gonadal sex differentiation in Tilapia mossambica with special regard to the time of estrogen treatment of effective inducing complete feminization of genetic males. Bull. Fac. Fish, 1-13.

Paessun MA, Allison R (1984) Maximizing tilapia production in recirculating systems by sequential rearing. Aquaculture, 42, 185-189.

Peter RE, Trudeau VL, Sloley BD, Peng C, Nahorniak CS (1991) Actions of catecholamines, peptides and sex steroids in regulation of gonadotropin-II in the goldfish. In: 4th Int. Symp. Reprod. Physiol. Fish (eds Scott AP, Sumpter JP, Kime DE, Rolfe MS). Fish Symp. 91, Sheffield, pp. 30.

Peter RE, Yu KL (1997) Neuroendocrine regulation of ovulation in fishes: basic and applied aspects. Reviews in Fish Biology and Fisheries, 7, 173-197.

Peters HM (1983) Fecundity, egg weight and oocyte development in tilapias (Cichlidae, Teleostei). In: ICLARM (ed Pauly D). 1-28, Manila, Philippines.

Philippart J-CL, Ruwet J-CL (1982) Ecology and distribution of tilapia. In: The Biology and Culture of Tilapias 7 (eds Pullin RSV, Lowe-McConnell RH). International Commission for Living and Aquatic Resources, Manila, pp. 15-59.

Puckhaber B (1992) Untersuchungen zur Produktivitätssteigerung bei afrikanischen Buntbarschen. Dissertation

Randall CF, Bromage N, Thorpe J, Miles M, Muir J, a. (1995) Melatonin rhythms in Atlantic salmon (Salmo salar) maintained under natural and out-of-phase seasonal photoperiods. Gen. Comp. Endocrinol., 73-87.

Ridha MT, Cruz EM (1999) Effect of different broodstock densities on the reproductive performance of Nile tilapia, Oreochromis niloticus (L.), in a recycling system. Aquaculture Research, 30, 203-210.

Rodriguez L, Zanuy S, Carrillo M (2001) Influence of daylength on the age at first maturity and somatic growth in male sea bass (Dicentrarchus labrax, L.). Aquaculture, 196, 159-175.

Rosenfeld H, Levavi-Sivan B, Gur G, Melamed P, Meiri I, Yaron Z, Elizur A (2001) Characterization of tilapia FSH[beta] gene and analysis of its $5^{\prime}$ flanking region. Comparative Biochemistry and Physiology Part B: Biochemistry and Molecular Biology, 129, 389-398. 
Rosenfeld H, Levavi-Sivan B, Levavi-Sivan B, Melamed P, Yaron Z, Elizur A (1997) The GTH $\beta$ subunits of tilapia: gene cloning and expression. Fish Physiology and Biochemistry, 17, 85-92.

Rothbard S, Ofir M, Levavi-Sivan B, Yaron Z (1991) Hormonal profile associated with breeding behaviour in Oreochromis niloticus. In: Proc. Fourth Int. Symp. Reprod. Physiol. Fish. (eds Scott AP, Sumpter JP, Kime DE, Rolfe MS). University of Sheffield Press, Sheffield, pp. 206.

Santiago CB, Reyes OS (1993) Effects of dietary lipid source on reproductive performance and tissue lipid levels of Nile tilapia Oreochromis niloticus (Linnaeus) broodstock. Journal of Applied Ichthyology, 9, 33-40.

Schulz R, Miura T (2002) Spermatogenesis and its endocrine regulation. Fish Physiology and Biochemistry, 26, 43-56.

Schwanck E (1987) Lunar periodicity in the spawning of Tilapia mariae in the Ethiop River, Nigeria. Journal of Fish Biology, 30, 533-537.

Scott AP (1987) Reproductive endocrinology of fish. In: Fundamentals of Comparative Vertebrate Endocrinology. Plenum Press, New York, USA.

Siddiqui AQ, Al-Harbi AH (1997) Effects of sex ratio, stocking density and age of hybrid tilapia on seed production in concrete tanks in Saudi Arabia. Aquaculture International, 5, 207-216.

Srisakultiew P, Wee KL (1988) Synchronous spawning of Nile Tilapia through hypophysation and temperature manipulation. In: The Second International Symposium on Tilapia in Aquaculture (ed Pullin RSV, Bhukaswan, T., Toguthai, K. and Maclean, J.L.). Department of Fisheries, Bangkok, Thailand and International Center for Living Aquatic Resources and Management, Manila, Philippines, ICLARM conference proceedings Bangkok, Thailand, pp 275-284

Stacey NE (1984) Control of the timing of ovulation by exogenous and endogenous factors. In: Fish reproduction: Strategies and Tactics. (ed. by Potts GW, Wootton RJ). Academic Press, London, pp. 207-222.

Stacey NE, Sorensen PW, Van der Kraak GJ, Dulka JG (1989) Direct evidence that 17a,20b-dihydroxy-4-pregnen-3-one functions as a goldfish primer pheromone: preovulatory release is closely associated with male endocrine responses. Gen. comp. Endocr., 75, 62-70.

Stamer A (2001) Laichszeitsteuerung bei Oreochromis niloticus (Pisces; Cichlidae) Untersuchungen zur Synchronisation von Laichfischbeständer in Kreislaufanlagen, Cuvillier Verlag Göttingen, Germany.

Suzuki K, Kawauchi H, Nagahama Y (1988) Isolation and characterization of two distinct gonadotropins from chum salmon pituitary glands. General and Comparative Endocrinology, 71, 292-301.

Tacon P, Ndiaye P, Cauty C, Le Menn F, Jalabert B (1996) Relationships between the expression of maternal behaviour and ovarian development in the mouthbrooding cichlid fish Oreochromis Niloticus. Aquaculture, 146, 261-275.

Taranger GL, Hansen T (1993) Ovulation and egg survival following exposure of Atlantic salmon, Salmo salar L., broodstock to different water temperatures. Aquacult. Fish.Manag., 24, 151-156.

Terkatin-Shimony A, Ilan Z, Yaron Z, Johnson DW (1980) Relationship between temperature, ovarian recrudescence, and plasma cortisol level in Tilapia aurea (Cichlidae, Teleostei). General and Comparative Endocrinology, 40, 143-148. 
Trewavas E (1983) Tilapiine Fishes of the Genera Sarotherodon, Oreochromis and Danaikilia., British Museum of Natural History, London.

Trudeau VL, Peter REI (1995) Functional interactions between neuroendocrine systems regulating GtH-II release. In: Reproductive Physiology of Fish, 1995. (ed. by Goetz FW, Thomas P). Fish Symposium 95, Austin, TX, pp. 44-48.

Turner GF, Phirl LM, Cawthraw S (1989) Partner attack inhibition in the sexually monomorphic biparental cichlid Tilapia mariae. Behaviour 109, 1-19.

Tyler CR, Sumpter JP (1996) Oocyte growth and development in teleosts. Reviews in Fish Biology and Fisheries, 6, 287-318.

Van den Hurk R, Schoonen WGEJ, Van Zoelen GA, Lambert JGD (1987) The biosynthesis of steroid glucuronides in the testis of the zebrafish, Brachydanio rerio, and their pheromonal function as ovulation inducers. General and Comparative Endocrinology, 68, 179-188.

Van der Kraak G, Chang JP, M. JD (1998) Reproduction. In: The physiology of fishes (ed by H. ED). CRC Press LLC, New York, pp. 465-483.

Van Der Kraak G, Pankhurst NW (1997) Temperature effects on the reproductive performance of fish. In: Global warming: Implications for freshwater and marine fish. (ed. by Wood CM, McDonald DG). Cambridge University Press, Cambridge, pp. 159-176.

Van der Meeren T, Ivannikov VP (2006) Seasonal shift in spawning of Atlantic cod (Gadus morhua L.) by photoperiod manipulation: egg quality in relation to temperature and intensive larval rearing. Aquaculture Research, 37, 898-913.

Van Weerd JH, Sukkel M, Bin Awang Kechik I, Bongers ABJ, Richter CJJ (1990) Pheromonal stimulation of ovarian recrudescence in hatchery-raised adult African catfish, Clarias gariepinus. Aquaculture, 90, 369-387.

Vilela DAR, Silva SGB, Peixoto MTD, Godinho HP, França LR (2003) Spermatogenesis in teleost: insights from the Nile tilapia (Oreochromis niloticus) model. Fish Physiology and Biochemistry, 28, 187-190.

Wildenhayn N (2002) Laichgeschehen bei früh- und spätlaichenden Stämmen der Regenbogenforelle (Oncorhynchus mykiss) unter Lichtprogrammbedingungen., Cuvillier Verlag, Göttingen.

Yaron Z, Gur G, Melamed P, Rosenfeld H, Elizur A, Levavi-Sivan B (2003) Regulation of fish gonadotropins. In: International Review of Cytology. Academic Press, pp. 131-185.

Yoshikawa H, Oguri M (1978) Sex differentiation in a cichlid, Tilapia zillii. Bull Jpn Soc Sci Fish, 313-318. 


\section{Chapter 2}

\section{CONTROL OF SPAWNING ACTIVITY IN FEMALE NILE TILAPIA (OREOCHROMIS NILOTICUS) (L.) BY TEMPERATURE MANIPULATION}

Boris Adrien de Lapeyre*, Andreas Müller-Belecke, Gabriele Hörstgen-Schwark Institute of Animal Husbandry and Genetics, Albrecht-Thaer-Weg 3, D-37075 Göttingen, Germany 


\section{Abstract}

The aim of this study was to maximise the spawning of Oreochromis niloticus females in a specific time period. Females were divided randomly into control and treatment groups. In the treatment groups, females were kept for one week at $28 \pm 0.5^{\circ} \mathrm{C}$, after which they were exposed to a reduced water temperature of $22 \pm 0.5^{\circ} \mathrm{C}$ for 7,14 and 28 days. Thereafter, the temperature was restored to $28^{\circ} \mathrm{C}$. Females in control groups were kept continuously at a water temperature of $28^{\circ} \mathrm{C}$. All females were checked daily for signs of spawning for the duration of the experiments and were manually stripped if ready to spawn. The following parameters were calculated for a period of 3 and 7 days following a $28^{\circ} \mathrm{C}$ temperature restoration: spawning rate, number of eggs per female, weight of female, relative fecundity (eggs $g^{-1}$ body weight), and the percentage of hatched and swim-up fry. The highest spawning rate of $39.5 \%$ was obtained in the $14 d$ trial over a period of $7 d$, while the corresponding value in the control was $12.5 \%$. The percentages of hatched and swim-up fry in the $14 d$ and $28 d$ trials, however, were significantly higher in the controls than in the corresponding treatment groups.

Keywords: Tilapia, spawning, temperature, stocking density

\section{Introduction}

The commercial importance of Nile tilapia (Oreochromis niloticus) is steadily increasing as larger quantities of this robust and easily farmed fish are offered on world markets. Consequently, research involving Nile tilapia is intensifying. The harvest of ovulated eggs or sperm at a give time is a prerequisite for selective breeding. Stripping sperm from tilapia males is, however, much easier than obtaining ovulated eggs from the females as several reproductive characteristics particular to the tilapia females pose problems which have to be overcome. Tilapia females, as asynchronous spawners, have an individual ovarian cycle and display a relatively low fecundity (Jalabert \& Zohar 1982). Therefore, the controlled production of the required unfertilised eggs is technically more demanding. A method that induces spawning in females at a chosen time would greatly facilitate the production of eggs for specific matings and as a consequence, make breeding programmes easier to perform, while at the same time allowing a reduction of the standing stock of breeders. Developing tilapia ovaries are synchronised by internal and external stimuli (Coward \& Bromage 2000). As external stimuli, light and temperature are known to be essential factors in the reproduction of 
tilapia (Rothbard \& Pruginin 1975). Photoperiod manipulation of tilapia, inspired by its use on salmonids (Bromage et al. 1984; Boeuf \& Le Bail 1999), has been shown to influence spawning in O. niloticus (Ridha \& Cruz 2000; Campos-Mendoza et al. 2004; Biswas et al. 2005). However, few studies have investigated the effect of temperature on the spawning activity of tilapia, although water temperature is known to be a climatic factor in the reproduction of natural tilapia populations (Lowe-McConnell 1959; Hyder 1970; Msiska \& Costa-Pierce 1997). Short-term (6-24 h) and long-term reductions in water temperatures $(1,2,3$ weeks $)$ to $22 \pm 1.5^{\circ} \mathrm{C}$ have been tested as a possible way to synchronize Nile tilapia (Srisakultiew \& Wee 1988). The most promising results were obtained during the experiments with short periods of treatment, during which $10-25 \%$ more females spawned than in the control. However, the females used in the experiments were chosen for their swollen belly and distended urogenital papilla. This criterion of selection would indicate that the fish were already close to spawning. The following experiment, however, was set up with adult Nile tilapia, which were not preselected in any way. Three different time periods (7, 14, and 28 days) were chosen with the aim of inducing a large number of females to spawn within a certain period ( 3 and 7 days).

\section{Materials and methods}

Oreochromis niloticus males and females of the Lake Manzala population were used in all experiments. This population is described in detail by Oldorf, Kronert, Balarin, Haller, Hörstgen-Schwark \& Langholz (1989) and Müller-Belecke (1997). The average weight of female breeders at the beginning of the experiments was $345 \mathrm{~g} \pm 75$. All females were used only once in each experiment. All trials were performed in the warm water recirculation system of the Institute of Animal Husbandry and Genetics, University of Göttingen. Water parameters measured during the experimental period were within the following range: oxygen $>7 \mathrm{mgL}^{-1}$; $\mathrm{pH} 6.5-7.5$; $\mathrm{NH}_{4}^{+}<0.1 \mathrm{mgL}^{-1}$; $\mathrm{NO}_{2}^{-}<0.4 \mathrm{mgL}^{-1}$. A photoperiod of 12 hours starting at 3:00 hours each morning was maintained throughout the trials.

For the experiments, two recirculation systems were set up; each consisting of three 300 $\mathrm{L}$ aquaria installed one above the other. Furthermore, each aquarium could be divided into 6 compartments, each with a volume of $50 \mathrm{~L}$, to accommodate individual stocking of fish as required. The two lowest aquaria, which contained no spawning substrate, were used to accommodate the spawners. The topmost aquarium was used as a settling 
tank with various substrates consisting of expanded clay and PVC particles (size 0.005$0.050 \mathrm{~m}$ ) for the mechanical and biological filtration of the water. Water was pumped from the lowest aquarium into the higher settling tank and circulated by gravity through the lower aquaria. It was possible to connect or disconnect these small recirculation systems from the central recirculation system of the institute, which maintained a constant temperature of $28 \pm 0.5^{\circ} \mathrm{C}$. Furthermore, each of the two small recirculation systems was fitted with a cooling unit (Titan 2000: Aqua Medic GmbH, Bissendorf, Germany). Males were kept only in the central recirculation system whereas females in the treatment groups were placed in the small recirculation systems. There was, however, an indirect contact between both sexes via the water as the small systems were connected to the central system when the water temperature was kept at $28^{\circ} \mathrm{C}$.

Temperature treatment involved placing female tilapia in the aquaria in groups of 12 or in individual compartments for 1 week until they were adjusted to their new environment, after which the ambient temperature of the water in the aquaria was reduced at a rate of $0.5^{\circ} \mathrm{Ch}^{-1}$ to $22 \pm 0.5^{\circ} \mathrm{C}$.

Three different treatments with a reduced water temperature of $22^{\circ} \mathrm{C}$ lasting 7,14 and 28 days respectively were tested on the fish. In the 7- and 28-day treatments, the females were stocked in groups of 12 (stocking density: $14 \mathrm{~kg} \mathrm{~m}^{-3}$ ) while in the 14-day treatment they were placed in individual compartments (stocking density: $7 \mathrm{~kg} \mathrm{~m}^{-3}$ ) to reduce the stress to the fish while checking for spawning signs. After these cool water periods, the temperature was restored to $28 \pm 0.5^{\circ} \mathrm{C}$. One trial was thus organised in the following three phases:

Acclimatisation phase: females were stocked in four aquaria at $28^{\circ} \mathrm{C}$ and given one week to get used to their new environment in the aquaria

Treatment phase: water temperature was reduced to $22^{\circ} \mathrm{C}$ for a period of 7,14 or 28 days

Spawning phase: temperature was restored to $28^{\circ} \mathrm{C}$ and the number of females ready to spawn was determined for a period of three and seven days.

In total 108,72 , and 168 females were available for the three trials. All female breeders were used only once in each experiment. In the temperature treatments $(7,14$ and 28 days of cooling), females were distributed randomly to control and treatment groups in such a way that all four aquaria in the two small recirculation systems were always stocked. Likewise, four aquaria in the central recirculation system were used for the controls. The control females were kept continuously at a constant temperature of $28^{\circ} \mathrm{C}$ 
in groups of 12 per $300 \mathrm{~L}$ ( 7 and 28 days of cooling) or in individual compartments (14 days cooling). Once all the treatment and control aquaria were fully stocked, the remaining breeders were used in additional aquaria to repeat the treatments and the control.

As a result, one, four and four extra aquaria were included, respectively, in the treatment part of the 7-,14- and 28-day trials, while two extra tanks were used in the control of the14- and 28-day trial respectively. Hence, in each of the three trials $(7,14$ and 28 days of cooling), a total of 60,48 and 96 females were subjected to the treatment and 48,24 and 72 females were used in the corresponding control respectively.

The spawning rate $(S)$ was defined as the percentage of females that spawned in each group in a 3 day period $\left(S_{3}\right)$ and a 7-day period $\left(S_{7}\right)$ respectively as the percentage of the total number of females in the group.

From acclimatization to spawning, females were observed for signs of spawning twice daily, the first time between 9:00 and 10:00 hours following $6 \mathrm{~h}$ of illumination and the second time between noon and 13:00 hours following $9 \mathrm{~h}$ of illumination. Most females could be stripped in the afternoon period, this corresponds in nature to the $3 \mathrm{~h}$ before sunset (photoperiod used: 03:00-15:00 hours). A red and distended urogenital papilla in combination with a swollen underbelly was a precursory sign that the female was going to spawn. The fish was removed from the aquarium and anaesthetized in water mixed with clove oil (4 drops per litre). Once the female stopped swimming it was stripped of its eggs by gently massaging the ventral part of its body immediately above the gonads and subsequently the female was weighed. The eggs were placed in a $0.9 \%$ saline solution and counted. Sperm was obtained from separately kept males by massaging the ventral part over the gonads and at the same time collecting the sperm with a pipette. From each batch of eggs, two random samples of 100 eggs were taken and fertilised with mixed sperm from 3 males. Five minutes after the eggs were fertilised in incubation cups $(0.02 \mathrm{~L})$, they were placed in the incubator and kept at $28^{\circ} \mathrm{C}$. Four days after fertilisation, the larvae were counted to determine the hatching rate (number of hatched eggs/number of fertilized eggs $\times 100$ ). Likewise, 9 days post-spawning, the number of swim-up fry was counted to obtain the swim-up rate (number of swim up fry/number of fertilized eggs $\times 100$ ). In addition, the relative fecundity of a particular breeder was calculated as the number of eggs per gram of its body weight.

Differences in spawning rates between the control and treatment group of each experiment were statistically analysed by Pearson's $\chi^{2}$ test $(2 \times 2$ contingency table $)$ at 
the $5 \%$ level of significance using the software package SPSS. Adopting descriptive statistics mean values of the number of eggs per female, weight of female, relative fecundity, hatching and swim-up rates of the control and experimental groups were compared by the $\mathrm{t}$-test at the $5 \%$ level of significance.

\section{Results}

No significant difference in the spawning rate, mean values of the number of eggs per female, weight of female, relative fecundity, hatching and swim-up rates was observed between females of the repeats in all trials.

In the acclimatization phase, females spawned both in the control and in the treatment groups. At the onset of the water cooling (the treatment phase), the frequency of spawning was considerably reduced in all treatment groups. During this phase, the number of females that spawned in each treatment group was nil in the 7-day period, two in the 14-day periodand four in the longest period spanning 28 days respectively.

An overview of spawning activity during all phases of the experiments is given in the bar charts Fig. 1a-c. The weeks where the females experienced a reduced water temperature are labelled, and the following week this was restored, during which spawning was expected to peak. Generally, the control values fluctuated less than the treatment values. 
Figure1. Spawning rates calculated for each week of trials: (a) 14-day treatment with water temperature at $22^{\circ} \mathrm{C}$ and individual stocking, (b) 7-day treatment with water temperature at $22^{\circ} \mathrm{C}$ and group stocking (c) 28-day treatment with water temperature at $22^{\circ} \mathrm{C}$ and group stocking.
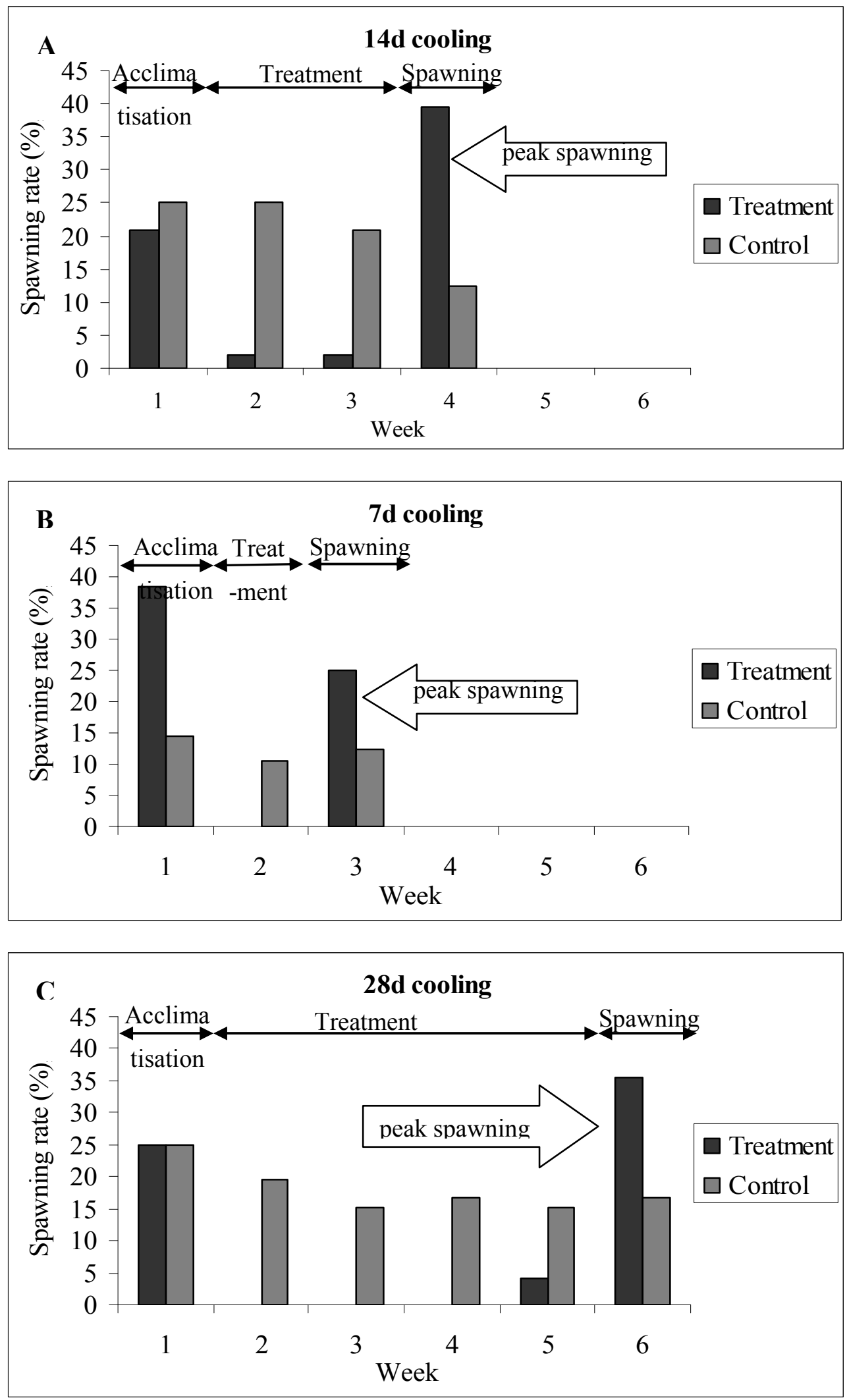


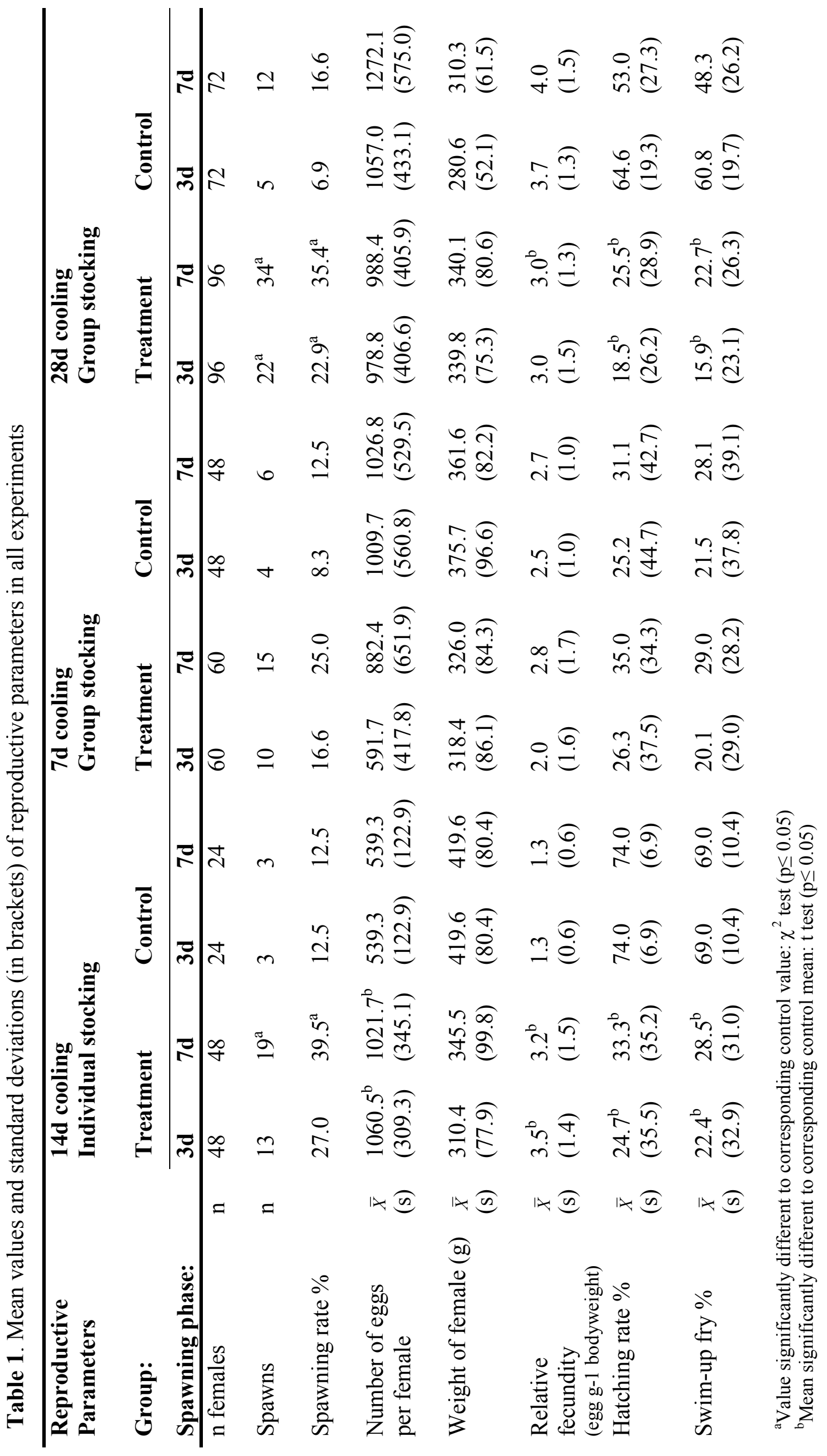


Table 1 summarizes the recorded reproductive parameters. The weight of females in the treatment and control groups did not show significant differences. Spawning rates in the 3- and 7-day spawning phases were always higher in the treatment than in the control groups for all 3 trials. However, these differences were significant $\left(\chi^{2}: p \leq 0.05\right)$ only in the 7-day spawning phase of the 14-day trial and in the 3- and 7-day spawning phases of the 28-day trial. The highest spawning rates for treated fish were observed after a 14day cooling treatment with $S_{3}=27.0 \%$ and $S_{7}=39.5 \%$ respectively. The lowest values were recorded after a 7-day treatment, with $S_{3}=16.6 \%$ and $S_{7}=25.0 \%$. In the control, females had the lowest spawning rates in the 14-day trial, with $S_{3}$ and $S_{7}=12.5 \%$, and the highest value of $S_{7}=16.6 \%$ in the 28 -day trial.

Generally in the 7- and 28-day treatment, no significant difference in the number of eggs per female and relative fecundity was observed between the treatment and control groups during the 3- and 7-day spawning phase. Only in the 7-day spawning phase of

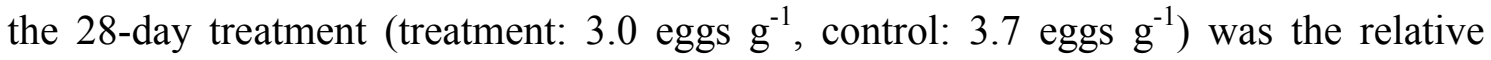
fecundity significantly $(t: p \leq 0.05)$ lower in the treatment than the control. On the other hand, the same parameters were significantly higher in the treatment than in the control group during the 3- and the 7-day spawning phase of the 14-day trial. These calculated values for the control of the 14-day treatment are, however, based on only three spawns. Hatching and swim-up rates were significantly lower $(t: p \leq 0.05)$ in the treatment groups of the 14- and 28-day trials than those in the corresponding controls, whereas these parameters were similar in magnitude in the treatment and control groups of the 7day trial. The hatching and swim-up rates during the 7-day spawning phase in the treatment groups were highest in the 7 -day trial $(35.0 \%$ and $29.0 \%$ respectively) and lowest in the 28 -day trial ( $25.5 \%$ and $22.7 \%$ respectively).

The 14-day cooling treatment showed the most promising results: $39.5 \%$ of females were made to spawn in the week following the end of cooling with a percentage of hatchlings and swim-up fry of $33.3 \%$ and $28.5 \%$ respectively. These hatching and swim-up rates were comparable to the ones observed in the 7-day treatment. The 7-day treatment was the shortest of all three temperature trials; this short cooling period of the water presumably had less of a negative effect on the percentage of hatchlings and swim-up fry. 


\section{Discussion}

This study showed that exposing tilapia females to water of $22^{\circ} \mathrm{C}$ for 7,14 and 28 days inhibited their spawning to a great extent. Higher spawning rates were observed 3-7 days after restoring a water temperature of $28^{\circ} \mathrm{C}$ than in the controls. The 14-day trial showed the best results. In this experiment, 39.5\% of all females spawned within a period of 7 days, whereas in the corresponding control only $12.5 \%$ spawned. Furthermore, on the last 2 days of the 7-day period, no spawns were recorded in both control and treatment group. This suggests that an even shorter spawning phase of 5 days can be used for practical purposes.

In general, the weight of the females was slightly higher in the controls than in the treatment groups except in the 28-day trial. The relative fecundity showed values in the range of 2-4 eggs $\mathrm{g}^{-1}$. This is comparable to the results obtained in preceding investigations (Stamer, 2001) with fish from the identical population kept in the same holding facilities. In these experiments females kept in groups of 12 showed a mean relative fecundity of 3.3 within a range of body weights of $250-350 \mathrm{~g}$. In this experiment, the relative fecundity of the control in the 14-day trial was noticeably poor $\left(1.3\right.$ eggs $\left.\mathrm{g}^{-1}\right)$. However, only three spawns were obtained here.

Excluding the 7-day trial, the hatching and swim-up rates obtained in the treatment groups averaged $<50 \%$ of the respective control values for a 3- and 7-day spawning phase. Hatching and swim-up rates tended to decrease with increasing duration of the treatment phase. A temperature of $22^{\circ} \mathrm{C}$ was selected as $O$. niloticus starts changing from being reproductively inactive to reproductively active around this temperature (Rothbard \& Pruginin 1975). In their experiment, Srisakultiew \& Wee (1988) suggest that keeping the fish at $22^{\circ} \mathrm{C}$ for long periods of time would result in the arrest of egg development and atresia of all vitellogenic oocytes, thus reducing oogenesis within individual fish as well as within a population to a uniform state, after which subsequent exposure to a normal high temperature would trigger rapid and synchronous oocyte maturation and ovulation. In their experiment, the percentage of mature eggs and the gonadosomal index of sampled spawners decreased drastically in the second and third weeks at $22.0^{\circ} \mathrm{C}$. This would partly explain why the rates of hatched larvae and swim- 
up fry decreased with increasing duration of the treatment phase, as the same temperature and similar durations were used in the present experiment.

Although the highest spawning rates were observed in the treatment group of the 14-day trial, the effect of the type of stocking (group or individual) cannot be excluded from the temperature effect. Individual stocking was introduced in the experiment to aid in observing the females for signs of spawning. In individual compartments, this was done faster and with less stress to the fish than when they were maintained in groups. Afterwards, it was realized that the type of stocking had to be taken in consideration as it affected the outcome of the results.

It is known that high stocking densities can inhibit spawning (Balarin \& Haller 1982; Paessun \& Allison 1984; Ridha \& Cruz 1999) A strong hierarchy among females decreases spawning incidence in a group (Fishelson 1983). Therefore, placing spawners in individual compartments eliminated any hierarchies and thereby reducing the stocking density that might have contributed to improved spawning. Experiments with Tilapia zillii (Gervais) showed that moving females from a group in a tank (stocking density $=\sim 20 \mathrm{~kg} \mathrm{~m}^{-3}$ ) to individual compartments induced $55 \%$ of females to spawn in at least one group within 10 days of being transferred (Coward et al. 1998). Although the spawning period was 3 days longer than the 7-day period used in this experiment, it suggests that higher spawning frequencies might be obtained with a change of stocking density alone. In succeeding investigations, the effect of stocking density will be investigated in more detail.

\section{Acknowledgements}

This work was supported by the Ministry for Science and Culture of Lower Saxony within the scope of a German-Israeli partnership. 


\section{References}

Balarin JD, Haller RD (1982) The intensive culture of tilapia in tanks, raceways and cages. In: Recent advances in aquaculture (ed. by Muir JF, Roberts RJ). Croom Helm, London, pp. 265-355.

Biswas AK, Morita T, Yoshizaki G, Maita M, Takeuchi T (2005) Control of reproduction in Nile tilapia Oreochromis niloticus (L.) by photoperiod manipulation. Aquaculture, 243, 229-239.

Boeuf G, Le Bail P-Y (1999) Does light have an influence on fish growth? Aquaculture, 177, 129-152.

Bromage NR, Elliott JAK, Springate JRC, Whitehead C (1984) The effects of constant photoperiods on the timing of spawning in the rainbow trout. Aquaculture, 43, 213-223.

Campos-Mendoza A, McAndrew BJ, Coward K, Bromage N (2004) Reproductive response of Nile tilapia (Oreochromis niloticus) to photoperiodic manipulation; effects on spawning periodicity, fecundity and egg size. Aquaculture, 231, 299314.

Coward K, Bromage NR (2000) Reproductive physiology of female tilapia broodstock. Reviews in Fish Biology and Fisheries, V10, 1-25.

Coward K, Bromage NR, Little DC (1998) Inhibition of spawning and associated suppression of sex steroid levels during confinement in the substrate-spawning Tilapia zillii. Journal of Fish Biology, 52, 152-165.

Fishelson L (1983) Social behaviour of adult tilapia fish in nature and in captivity In: Proceedings of the International Symposium on Tilapia in Aquaculture (eds Fishelson L, Yaron Z). Tel Aviv University Press, Tel Aviv, Israel, pp. 48-58.

Hyder M (1970) Gonadal development and reproductive activity of the cichlid fish Tilapia leucosticta (Trewavas) in an equatorial Lake: Lake Naivvasha (Kenya). Journal of Zoology, 162, 179-195.

Jalabert B, Zohar Y (1982) Reproductive physiology in cichlid fishes, with particular references to Tilapia and Sarotherodon. In: The Biology and Culture of Tilapia. ICLARM conference proceedings 7 (eds Pullin RSV, Lowe-McConnell RH). ICLARM, Manila, pp. 129-140.

Lowe-McConnell RH (1959) Breeding behaviour patterns and ecological differences between Tilapia species and their significance for evolution within the genus Tilapia (Pisces: Cichlidae). Proc. Zool., 132, 1-30.

Msiska OV, Costa-Pierce BA (1997) Factors influencing the spawning success of Oreochromis karongae (Trewavas) in ponds. Aquaculture Research, 28, 87-99.

Müller-Belecke A (1997). Entwicklung homozygoter Zuchtlinien bei Tilapien, Oreochromis niloticus. Cuvillier Verlag, Göttingen, ISBN 3-89588-939-3, 135 pp.

Oldorf W, Kronert U, Balarin J, Haller J, Hörstgen-Schwark G, Langholz HJ (1989) Prospects for selecting on late maturity in Tilapia (Oreochromis niloticus). I. Strain comparisons under laboratory and field conditions. Aquaculture, 77, 123133.

Paessun MA, Allison R (1984) Maximizing tilapia production in recirculating systems by sequential rearing. Aquaculture, 42, 185-189. 
Ridha MT, Cruz EM (1999) Effect of different broodstock densities on the reproductive performance of Nile tilapia, Oreochromis niloticus (L.), in a recycling system. Aquaculture Research, 30, 203-210.

Ridha MT, Cruz EM (2000) Effect of light intensity and photoperiod on Nile tilapia Oreochromis niloticus L. seed production. Aquaculture Research, 31, 609-617.

Rothbard S, Pruginin Y (1975) Induced spawning and artificial incubation of Tilapia. Aquaculture, 5, 315-321.

Srisakultiew P, Wee KL (1988) Synchronous spawning of Nile Tilapia through hypophysation and temperature manipulation. In: The Second International Symposium on Tilapia in Aquaculture (ed Pullin RSV, Bhukaswan, T., Toguthai, K. and Maclean, J.L.). Department of Fisheries, Bangkok, Thailand and International Center for Living Aquatic Resources and Management, Manila, Philippines, ICLARM conference proceedings Bangkok, Thailand, pp 275-284

Stamer, A. (2001) Laichzeitsteuerung bei Oreochromis niloticus (Pisces; Cichlidae): Untersuchungen zur Synchronisation von Laichfischbeständen in Kreislaufanlagen, pp 130. Cuvillier-Verlag Göttingen, ISBN 3-89873-514-1 


\section{Chapter 3}

\section{INCREASED SPAWNING ACTIVITY \\ OF FEMALE}

NILE TILAPIA (OREOCHROMIS NILOTICUS) (L.)

AFTER STOCKING DENSITY

AND PHOTOPERIOD MANIPULATION

Boris Adrien de Lapeyre*, Andreas Müller-Belecke, Gabriele Hörstgen-Schwark

Institute of Animal Husbandry and Genetics, Albrecht-Thaer-Weg 3,

D-37075 Göttingen, Germany

In press Aquaculture Research

(doi:10.1111/j.1365-2109.2010.02548.x) 


\section{Abstract}

This study was conducted to evaluate the effects of stocking density and photoperiod in increasing the reproductive performance of Oreochromis niloticus. In experiment 1, a change in stocking density (from 47.7 to $6.8 \mathrm{~kg} \mathrm{~m}^{-3}$ ) was performed, with groups of 48 females moved to single compartments. In experiment 2, 36 females experienced a $6 L: 18 D$ photoperiod for 21 or 28 days (stocking density: $31.3 \mathrm{~kg} \mathrm{~m}^{-3}$ ) before being placed in individual compartments (stocking density of $6.9 \mathrm{~kg} \mathrm{~m}^{-3}, 12 \mathrm{~L}: 12 \mathrm{D}$ photoperiod). The spawning rates in experiment 1 (32.2\%) and in experiment 2 (21d: 65.2\%, 28 days: 36.1\%) were significantly higher than in the control (17.7\%). On the other hand, hatching and swim-up fry rates were significantly lower in experiment 2 - 21 days (41.3\%, 40.4\%) but not in experiment 1 (64.0\%, 56.3\%) compared to the control (67.0\%, 62.3\%). The spawning rate in experiment 2 - 21-day treatment group was the highest, while the number of eggs collected per female were significantly lower than in the control. In experiments 1 (20.8\%) and 2 (21 days: 44.4\%, 28 days: 19.4\%), the daily spawning rates werethe highest 3 days after maintaining females in single compartments. The current experiment demonstrates how specific stocking density changes can be used to induce higher spawning rates in Nile tilapia.

Keywords: Oreochromis niloticus, spawning, photoperiod, stocking density

\section{Introduction}

A prerequisite for research aimed at performing manipulations such as gynogenesis, hybridization or sex inversion with Nile tilapia is the harvesting of sufficient quantities of unfertilized eggs and sperm. Obtaining sperm is unproblematic. However, stripping females for ovulated eggs at a pre-determined point in time is difficult because each tilapia spawner follows an independent ovarian cycle (Jalabert \& Zohar 1982). Thus, obtaining enough eggs involves continuous observation of females for signs of imminent spawning before they can be stripped of their eggs. A method that would condition females to spawn at a predetermined time, either through the control of the timing of ovulation or through the inducement of the ovulatory process, would make egg production much easier.

Reproductive mechanisms in nature ensure that larvae and young fish grow in an environment most propitious for their survival (Coward \& Bromage 2000; Bromage et al. 2001). In most fish, several environmental factors, for instance photoperiod, temperature, rainfall or availability of food, are known to regulate such mechanisms (Bromage et al. 2001). Although 
there is considerable literature in this respect on seasonal fish, particularly salmonids (Bromage et al. 1984; Pankhurst, Purser, Van Der Kraak, Thomas \& Forteath 1996; Boeuf \& Le Bail 1999), it is also believed that photoperiod, temperature and rainfall play an important role in cueing the reproduction of tropical and subtropical fish (Bromage et al. 2001). Some factors that have been shown to influence reproduction in tilapiines include: photoperiodic manipulation (Ridha \& Cruz 2000; Campos-Mendoza et al. 2004; Biswas et al. 2005; ElSayed \& Kawanna 2007), temperature (Terkatin-Shimony et al. 1980; Srisakultiew \& Wee 1988), stocking density (Srisakultiew \& Wee 1988; Coward et al. 1998; Ridha \& Cruz 1999), and diet (El-Sayed et al. 2005). Different photoperiod and temperature combinations have also been tested on cyprinids (Okuzawa, Furukawa, Aida \& Hanyu 1989).

In this experiment, stocking density changes were investigated with regard to their impact on spawning activity. The implementation of the method is uncomplicated under practical conditions. Additionally, photoperiod manipulation was combined with stocking density treatment as it is generally accepted to be one of the most important factors in cueing reproduction in fish (Bromage et al. 2001). In foregoing studies, the same population of fish was subjected to temperature treatments in groups or single stocking (De Lapeyre, MüllerBelecke \& Hörstgen-Schwark 2009). A positive effect of individual stocking was observed on spawning rates but could not be isolated from the temperature effect. Furthermore, it was also found that most spawns could be collected during a 5-day period after treatment. This study systematically investigated the effect of a stocking density change alone and in combination with a photoperiod manipulation using adequate numbers of tilapia females with an aim to induce a maximum number of spawns within a 5-day period.

\section{Materials and method}

\section{Experimental Fish}

The spawning experiment was carried out in the warmwater recirculation system of the Institute of Animal Husbandry and Genetics, University of Göttingen with male and female Oreochromis niloticus of the Lake Manzala population. This population has been described in detail by Tessema, Müller-Belecke and Hörstgen-Schwark (2006).. The weight of the fish was $328 \pm 51$ g. Without prior conditioning, each fish was exposed only once to treatment per experiment.

\section{Recirculation system}

The water temperature was maintained at $28 \pm 0.5^{\circ} \mathrm{C}$ in the recirculation system and water parameters were measured to be within the following range: oxygen $>7 \mathrm{mg} \mathrm{L}^{-1}$; $\mathrm{pH}$ 6.5-7.5; 
$\mathrm{NH}_{4}^{+}<0.1 \mathrm{mg} \mathrm{L}{ }^{-1}$; and $\mathrm{NO}_{2}^{-}<0.4 \mathrm{mg} \mathrm{L}^{-1}$. Except during the photoperiod experiments, a normal photoperiod of 12 hours starting at 03:00 hours was instituted throughout the trials. Up to nine glass aquaria (capacity: $0.3 \mathrm{~m}^{-3}$ ) were connected to the recirculation system of the research facility and were used to observe the females. These aquaria were set up in an array of three groups side by side, each group consisting of three superposed aquaria and stocked according to the availability of fish. During treatment, the females were stocked individually by dividing each aquarium into six compartments (capacity: $0.05 \mathrm{~m}^{-3}$ ). The control fish were placed in the aquaria without compartments. Before being stocked in the aquaria, the females were maintained as a single group in fiberglass tanks. The first tank (capacity: $1.0 \mathrm{~m}^{-3}$ ) linked to the recirculation system was used for the purpose of stocking density treatment, while photoperiod manipulations were performed in the second tank (capacity: $0.8 \mathrm{~m}^{-3}$ ). Two watertight fluorescent tubes were placed $50 \mathrm{~cm}$ above this holding tank at a light intensity of 2500 1x. A light-opaque plastic sheet draped over the light source and fixed to the tank ensured that no light other than from the fluorescent tube reached the fish. The light was connected to an electronic timer, which allowed for the daily programming of photoperiods.

\section{Stocking density and photoperiod treatments}

The standard method for obtaining eggs from the females in the recirculation system was performed as follows: a random sample of 48 fish was removed from a group of females maintained in the $1.0 \mathrm{~m}^{-3}$ fiberglass tank for 7 days at a stocking-density of $47.7 \mathrm{~kg} \mathrm{~m}^{-3}$. These were transferred to four glass aquaria for 7 days, where they were kept in groups of 12 per aquarium (stocking-density: $13.8 \mathrm{~kg} \mathrm{~m}^{-3}$ ). This standard method was replicated under the same conditions twice with different fish and used as the control.

Experiment 1 was conducted similarly to the control, except that the females were individually stocked when transferred to eight glass aquaria by placing them in single compartments (six fish per aquarium) for 7 days at a of stocking-density of $6.8 \mathrm{~kg} \mathrm{~m}^{-3}$. This experiment was replicated twice.

In experiment 2, 72 females were maintained in the $0.8 \mathrm{~m}^{-3}$ fibreglass tank at a stocking density of $31.3 \mathrm{~kg} \mathrm{~m}^{-3}$. The photoperiod was set at $6 \mathrm{~h}$ of light and $18 \mathrm{~h}$ of darkness (6L:18D). Experiment 2a: after 21 days, 36 females were removed from the tank and placed in the single compartments of six aquaria for a period of 7 days at a stocking density of $6.9 \mathrm{~kg} \mathrm{~m}^{-3}$ and a photoperiod of $12 \mathrm{~h}$ of light and $12 \mathrm{~h}$ of darkness (12L:12D). This experiment was replicated twice. Experiment 2b: after 28 days, the remaining 36 females were also removed from the tank and put in the single compartments. This experiment was run with only one replicate. 


\section{Stripping and fertilization of eggs}

The glass aquaria allowed for an easy inspection of the females. Between 9:00 and 10:00 hours and between 12:00 and 1:00 hours, females close to spawning were indentified. Experience showed that most females could be stripped between 12:00 and 1:00 hours, that is after a light period of $9-10$ hours. Typical signs of imminent spawing observed were a red and distended urogenital papilla, a swollen abdomen, aggressive behaviour or body colour changing to red. Any female showing such signs was removed and anaethesized with clove oil (4 drops $\mathrm{L}^{-1}$ ) before being weighed. By gentle massage of the abdominal region, the fish was stripped of its eggs which were placed immediately in a $0.9 \%$ saline solution and counted. In a similar manner, males maintained seperately from females were stripped and the sperm was collected with a pipette. Fertilization was conducted by mixing two random samples of 100 eggs collected from each batch of eggs with sperm from three males. In some cases, it was not possible to fertilize the eggs; for example, when the female had already spawned on its own or when the eggs collected were too few and/or of bad quality. This batch of eggs was still recorded as a spawning event but not fertilized. Inseminated eggs were incubated at $28^{\circ} \mathrm{C}$ in incubation glasses $(0.02 \mathrm{~L})$. A small tap over each glass provided a constant stream of warm water to keep the eggs rotating gently. The hatching rate was calculated by counting the number of larvae 4 days after fertilization (number of hatched eggs / number of fertilized eggs $\mathrm{x} 100$ ) and the swim-up rate by counting the the number of swim-up fry (number of swim up fry / number of fertilized eggs x 100). In addition, the relative fecundity of the female breeder was calculated by the number of eggs per gram of body weight of the spawner. Except for the 28-day treated group in experiment 2, each experiment was replicated twice with the same number of but different fish. This ensured that each fish was used only once per replicate. The results obtained from the repeats did not differ significantly and were summarized over both replicates. The spawning rate $(S)$ was defined as the percentage of females that spawned over a period of 5 days $\left(S_{5}\right)$ out of the total number of females in each group. To compare the daily changes in spawning, the daily spawning rate $\left(S_{1}\right)$ was defined as the percentage of females that spawned on each of the observation days out of the total number of females in each group. In order to compare the stocking density change in each experiment, the stocking density ratio was defined as the ratio of 'the stocking density of the fish before transfer' in relation to 'the stocking density of the fish after the transfer'. 


\section{Data analysis}

Differences in spawning rates between the control and experimental groups 1-3 were statistically analysed by Pearson's $\chi^{2}$ test $(2 \times 2$ contingency table $)$ at the $5 \%$ level of significance using the software package SPSS. The mean values of the number of eggs per female, relative fecundity, hatching and swim-up rates were tested for normality (ShapiroWilk) and experimental groups were compared to the control by the $t$-test at the $5 \%$ level of significance.

\section{Results}

\section{Control}

The stocking density ratio was of 3.4:1.0. It was possible to strip the first females on day 2 . Summarized over the two control groups (Fig. 1), the distribution of daily spawning $\left(S_{1}\right)$ from day 2 to day 5 varied from 1.0 to $7.2 \%\left(S_{1}=1.0 \%, 7.2 \%, 4.1 \%\right.$, and $5.2 \%$ respectively). Reproductive parameters for means of the control groups (Table 1) are summarized over both groups. A spawning rate, $S_{5}$, of $17.7 \%$ was calculated for females maintained in groups of 12 spawned over the $5 \mathrm{~d}$ period. The collected eggs that were fertilized hatched with a mean hatching rate of $67.0 \%$ and a swim-up rate of $62.3 \%$.

\section{Experiment 1 - Stocking density change}

The ratio of stocking densities was of 7.0:1.0. Females exhibited first spawning signs on day 3 which coincided with a peak of spawning activity, $S_{1}=20.8 \%$, (Fig. 1). On day 4 and day 5 , daily spawning rates were relatively low $\left(S_{1}=7.3 \%\right.$ and $4.2 \%$ respectively). Over the $5 \mathrm{~d}$ period (Table 1), a spawning rate, $S_{5}$, of $32.2 \%$ was calculated for the females maintained in single compartments. This was a significantly higher percentage than in the control. Unlike the spawning rate, the mean hatching rate, $64.0 \%$, and swim-up rate, $56.3 \%$, of the eggs collected in expriment 1 were not significantly different from the control.

\section{Experiment 2 - Photoperiod manipulation}

The ratio of stocking densities was 4.5:1.0. After being transferred to aquaria from a photoperiod treatment of $21 \mathrm{~d}$ at $6 \mathrm{~L}: 18 \mathrm{D}$, the first females could be stripped on day $2, S_{1}=$ $8.3 \%$. On day 3 , the highest daily spawning rate was recorded, $S_{1}=44.4 \%$ (Fig. 1). Females transferred after 28 days of photoperiod treatment were stripped only during two days. The $S_{1}$ rates were $19.4 \%$ on day 3 and $16.7 \%$ on day 4 (Fig. 1). Females transferred after 21 days of photoperiod treatment reached a spawning rate, $S_{5}$, of $65.2 \%$ (Table 1), which was a 
significantly higher proportion than in the control, $S_{5}=17.7 \%$. The $S_{5}$ rate of the females kept for 28 days at a photoperiod of 6L:18D was calculated at $36.1 \%$, also significantly higher than in the control for the same 5-day period after transfer to individual compartments. The number of eggs per female (896.5 eggs), relative fecundity (2.6 eggs $\mathrm{g}^{-1}$ body weight), hatching rates $(41.3 \%)$ and swim-up rates of fry $(40.4 \%)$ in the 21 -day treatment group were significantly lower than in the control.

Table 1: Mean values and standard deviations (in brackets) of reproductive parameters and spawning rate $\left(S_{5}\right)$ of all experiments in a 5 day spawning period post transfer of fish

\begin{tabular}{|c|c|c|c|c|c|}
\hline \multirow{3}{*}{$\begin{array}{l}\text { Reproductive } \\
\text { Parameters }\end{array}$} & & \multirow[t]{3}{*}{ Control } & \multirow{3}{*}{$\begin{array}{c}\text { Experiment } 1 \\
\text { Stocking } \\
\text { density } \\
\text { change } \\
\end{array}$} & \multirow{2}{*}{\multicolumn{2}{|c|}{$\begin{array}{c}\text { Experiment } 2 \\
\text { Photoperiod } \\
\text { of } 6 \mathrm{~L}: 18 \mathrm{D}\end{array}$}} \\
\hline & & & & & \\
\hline & & & & $\begin{array}{l}\text { Exp. 2a: } \\
\text { 21d }\end{array}$ & $\begin{array}{l}\text { Exp. 2b: } \\
28 \mathrm{~d}\end{array}$ \\
\hline $\mathrm{n}$ females & & 96 & 96 & 72 & 36 \\
\hline Spawns & $\mathrm{N}$ & 17 & 31 & 47 & 13 \\
\hline $\begin{array}{l}\text { Spawning rate } \\
\text { (S5) \% }\end{array}$ & & 17.7 & $32.2^{\mathrm{a}}$ & $65.2^{\mathrm{a}}$ & $36.1^{\mathrm{a}}$ \\
\hline $\begin{array}{l}\text { Spawns } \\
\text { fertilized }\end{array}$ & $\mathrm{N}$ & 12 & 20 & 30 & 5 \\
\hline $\begin{array}{l}\text { Number of } \\
\text { eggs } \\
\text { per female }\end{array}$ & $\begin{array}{l}\bar{X} \\
(s)\end{array}$ & $\begin{array}{l}1256.4 \\
(485.9)\end{array}$ & $\begin{array}{l}822.7^{b} \\
(584.4)\end{array}$ & $\begin{array}{l}896.5^{b} \\
(320.2)\end{array}$ & $\begin{array}{c}964.2 \\
(242.3)\end{array}$ \\
\hline $\begin{array}{l}\text { Weight of } \\
\text { Females }\end{array}$ & $\begin{array}{l}\bar{X} \\
(s)\end{array}$ & $\begin{array}{l}328.6 \\
(51.7)\end{array}$ & $\begin{array}{l}365.4 \\
(65.5)\end{array}$ & $\begin{array}{c}388.6 \\
(195.9)\end{array}$ & $\begin{array}{l}319.2 \\
(85.1)\end{array}$ \\
\hline $\begin{array}{l}\text { Relative } \\
\text { Fecundity* }\end{array}$ & $\begin{array}{l}\bar{X} \\
(s)\end{array}$ & $\begin{array}{l}3.8 \\
(1.3)\end{array}$ & $\begin{array}{l}2.2^{b} \\
(1.6)\end{array}$ & $\begin{array}{l}2.6^{b} \\
(1.0)\end{array}$ & $\begin{array}{c}3.0 \\
(0.1)\end{array}$ \\
\hline $\begin{array}{l}\text { Hatching } \\
\text { rate } \%\end{array}$ & $\begin{array}{l}\bar{X} \\
(s)\end{array}$ & $\begin{array}{c}67.0 \\
(15.4)\end{array}$ & $\begin{array}{c}64.0 \\
(22.0)\end{array}$ & $\begin{array}{l}41.3^{b} \\
(21.5)\end{array}$ & $\begin{array}{c}54.6 \\
(26.7)\end{array}$ \\
\hline $\begin{array}{l}\text { Swim-up } \\
\text { fry } \%\end{array}$ & $\begin{array}{l}\bar{X} \\
(s)\end{array}$ & $\begin{array}{c}62.3 \\
(15.2)\end{array}$ & $\begin{array}{c}56.3 \\
(19.3)\end{array}$ & $\begin{array}{l}40.4^{b} \\
(21.5)\end{array}$ & $\begin{array}{c}48.8 \\
(24.3)\end{array}$ \\
\hline
\end{tabular}

${ }^{\mathrm{a}}$ Value significantly different from $\Sigma$ control value: $\chi^{2}$ test ( $\mathrm{p}$ ? 0.05)

${ }^{b}$ Mean significantly different from $\Sigma$ control mean: $t$ test ( $p$ ? 0.05 )

* Eggs per gram body weight 


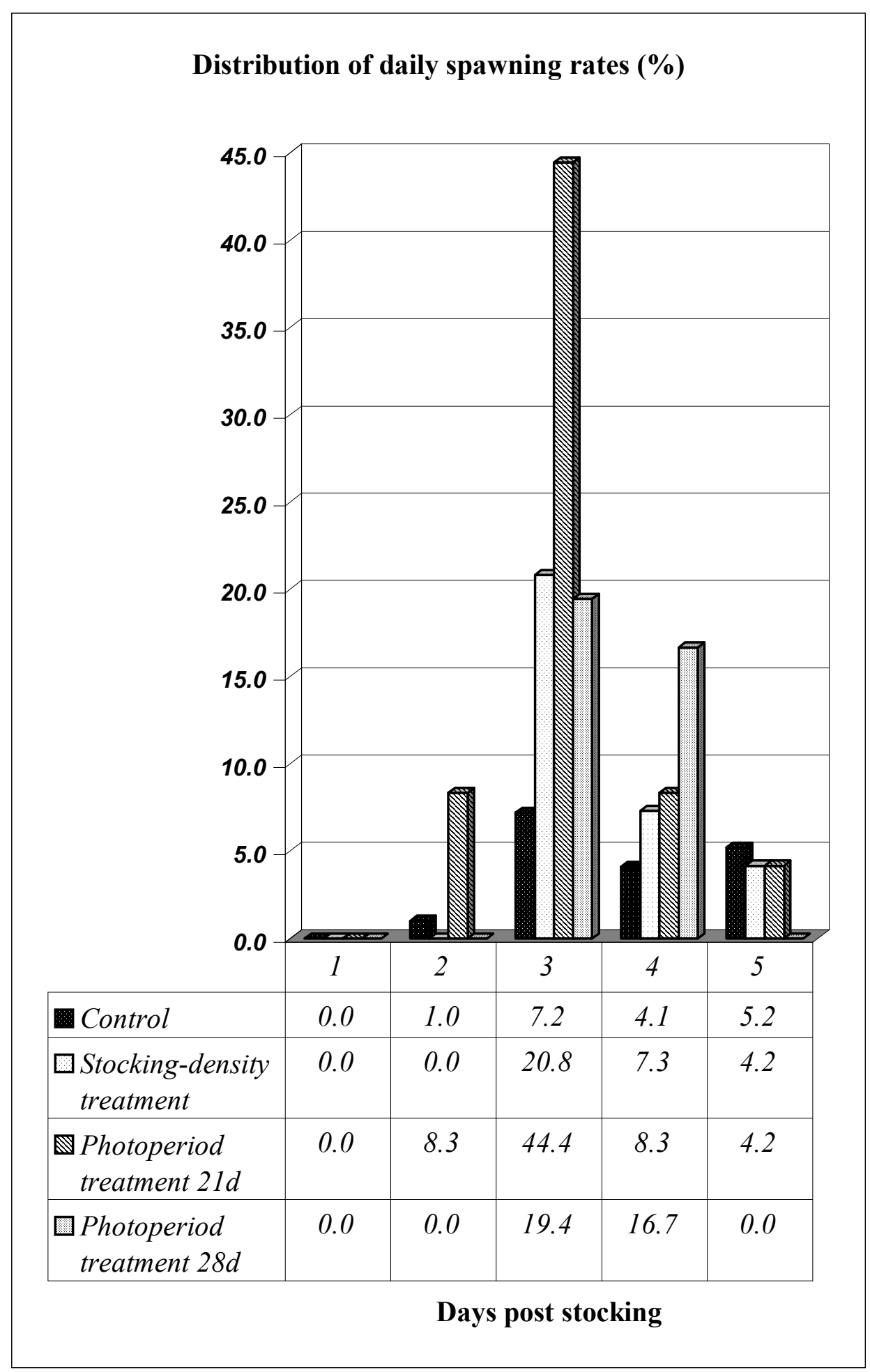

Figure 1: Distribution of daily spawning rates $\left(S_{1}\right)$ at 5 observation days summarized over replicates 


\section{Discussion}

The present study clearly shows that stocking density treatment had a marked effect on spawning in Nile tilapia when compared with the control. The stocking density treatment on its own induced a significantly higher $\left(S_{5}=32.2 \%\right)$ spawning rate than in the control $\left(S_{5}=\right.$ 17.7\%). However, from previous research (De Lapeyre et al. 2009) it was shown that combining a 14-day temperature treatment at $22^{\circ} \mathrm{C}$ with individual stocking induced more females to spawn $\left(S_{5}=39.5 \%\right)$. In experiment 2, a photoperiodic treatment at $6 \mathrm{~L}: 18 \mathrm{D}$ before a change in density treatment had a still stronger effect on spawning rates $\left(S_{5}=65.2 \%\right)$.

From daily measurements, it was observed that no fish were ready to be stripped 1 day immediately after moving to aquaria, while a few fish were stripped 2 days after transfer (experiment 2a: $S_{1}=8.3 \%$, control: $S_{1}=1.0 \%$ ). This could be due to females acclimatizing to their new environment after the stress involved in their transfer from the tank. In both experiments, the highest daily spawning rates were observed 3 days after stocking (experiment 1: $S_{1}=20.8 \%$, experiment 2a: $S_{1}=44.4 \%$, experiment $2 \mathrm{~b}: S_{1}=19.4 \%$ ). This elevated level of spawning at such a regular interval suggests a delayed reaction to the stress of new stocking.

Although the weights of females in experiment $2 \mathrm{~b}(319.2 \pm 85.1 \mathrm{~g})$ and in the control $(328.6 \pm 51.7 \mathrm{~g})$ were on average lower than in experiment $1(365.4 \pm 65.5 \mathrm{~g})$ and in experiment $2 \mathrm{a}(388.6 \pm 195.9 \mathrm{~g})$, there was no significant difference in the mean values. A high variation in weight is observed as batches of females were selected on basis of age and not weight. This was done in view of obtaining results applicable to the natural population of O. niloticus. The number of eggs per female was weighed with the weight of the female to compare the relative fecundity between groups. The range for this parameter was between 2 and 4 eggs g ${ }^{-1}$ body weight, also comparable to previous results (De Lapeyre et al. 2009).

In experiment 1 , it was shown that moving the fish to single compartments at a low stocking density of $6.9 \mathrm{~kg} \mathrm{~m}^{-3}$ (stocking density ratio: 7.0:1.0) induced more females to spawn than when they were moved in the control to groups of 12 at $13.8 \mathrm{~kg} \mathrm{~m}^{-3}$ (stocking density ratio: $3.4: 1.0)$. As the fish came from the same holding tank with a high stocking density (47.7 $\mathrm{kg} \mathrm{m}^{-3}$ ), it appears that the difference in stocking densities before and after moving the fish exerted a more pronounced effect on spawning. On the other hand, the stocking density ratio was not substantialy higher for experiment 2 (4.5:1.0) than for the control, and yet higher spawning rates were achieved. Conditioning due to photoperiod manipulations or the group behaviour of the females could possibly explain this difference. The control fish were kept in groups of 12 , while they were individually stocked in experiment 1 and 2, which broke down 
the group. Experiments with Tilapia zillii (Gervais) might explain these observations; in at least one group, $55 \%$ of females transferred from crowded holding tanks (stocking density $=\sim$ $20 \mathrm{~kg} \mathrm{~m}^{-3}$ ) to individual compartments spawned in a period of 10 days post transfer (Coward et al. 1998). At high stocking densities, the females adopt a schooling behaviour which halts their reproductive activity (Balarin et al. 1986).Placing the females in smaller groups or individual compartments as in the current experiment could have influenced their schooling behaviour or completely disrupted it, bringing about favourable conditions for spawning.

In experiment 2 stocking density treatment was combined with a photoperiod of $6 \mathrm{~L}: 18 \mathrm{D}$ for 21 and 28 days. It was not possible to measure the spawning activity of the females while they were kept together in the holding tank as checking each female would have caused them too much stress and could have altered the outcome of the experiment. There is evidence that very short periods of light can inhibit spawning in Nile tilapia (Biswas et al. 2005), as it was observed that reproduction was stopped at a $6 \mathrm{~L}: 6 \mathrm{D}$ photoperiod. The very high spawning rate, $\mathrm{S}_{5}(65.2 \%)$, measured after the females were held for 3 weeks at a photoperiod of $6 \mathrm{~L}: 18 \mathrm{D}$, indicates that reproduction might have been strongly suppressed while they were kept in a single tank, as a large proportion of females spawned once their holding conditions were changed (single stocking, 12L:12D photoperiod). Other experiments with Tilapia females held at a $12 \mathrm{~L}: 12 \mathrm{D}$ photoperiod caused higher spawing rates than at a photoperiod of $6 \mathrm{~L}: 18 \mathrm{D}$ (El-Sayed \& Kawanna 2007). Besides the change in stocking density in experiment 2b, it is therefore suggested that the additional cue of altering the photoperiod from a sub-optimal (6L:18D) to a better environment (12L:12D) induced such high spawning rates. At the same time relative fecundity, hatching and swim-up fry rates were significantly lower in experiment 2a $(2.6,41.3 \%, 40.4 \%)$ compared to the control $(3.8,67.0 \%, 62.3 \%)$. As the gonadal development before the spawning occurred under a $6 \mathrm{~L}: 18 \mathrm{D}$ photoperiod as opposed to a 12L:12D photoperiod in the control, these parameters seem to have been negatively influenced by the 21-day photoperiod of 6L:18D. These results are similar to the results of ElSayed \& Kawanna (2007) where the total number of eggs per female and eggs per spawn were significantly higher at a $12 \mathrm{~L}: 12 \mathrm{D}$ photoperiod $(1619,491)$ than at a $6 \mathrm{~L}: 18 \mathrm{D}$ photoperiod $(556,350)$. A possible explanation is that more energy was invested in growth than in gonadal development (Biswas et al. 2005), and this directly influenced the relative fecundity, hatching and swim-up fry rates. On the other hand, the group that was kept 1 week longer at a $6 \mathrm{~L}: 18 \mathrm{D}$ photoperiod did not have such a high spawning rate (36.1\%). As both groups (21 and 28 days) were housed in the same holding tank and the first group was removed 1 week before the second one, an intermedial reduction in the stocking density from 25 to $13 \mathrm{~kg} \mathrm{~m}^{-3}$ occurred for 
the second group during a 1-week period before tranfer to individual stocking. This might have been enough of a change to cause some of the females to spawn right before they were placed in the solitary compartments, explaining the lower $36.1 \%$ spawning rate.

\section{Conclusion}

The combination of photoperiodic and stocking density manipulation induced the highest spawning rate of $\mathrm{S}_{5}=65.2 \%$ for the 21 -day photoperiod group. At the same time, the hatching and swim-up fry rates were significantly lower than those in the control. The longer photoperiod treatment of 28 days induced a lower spawning rate $(\mathrm{S}=36.1 \%)$; however, the hatching and swim-up fry rates were not significantly lower than the ones in the control.

Experiment 1 was straightforward in its implementation. Most females spawned 3 days after their transfer, while their hatching and swim-up rates were comparable with the control. This method was the most practical for obtaining a large number of good-quality eggs in a short 10-day planning period (7 days at a high density stocking and 3 days at a low stocking density, ratio of stocking densities: 7.0:1.0).

Assuming that the trigger that induces spawning in response to a stocking density change is genetically determined, breeders could be selected for this trait. Based on their sensitivity to such treatments, a line could be bred that responds to a stocking density change with high spawning rates.

\section{Acknowledgements}

This work was supported by the Ministry for Science and Culture of Lower Saxony within the scope of a German-Israeli partnership. 


\section{References}

Balarin JD, Haller RD, Armitage AT (1986) Research on Intensive Culture of Tilapia in Tanks. In: Aquaculture research in the Africa region: proceedings of the African Seminar on Aquaculture, organised by the International Foundation for Science (IFS), Stockholm (ed Huisman EA). Pudoc, 1986, Wageningen, pp. 206-216.

Biswas AK, Morita T, Yoshizaki G, Maita M, Takeuchi T (2005) Control of reproduction in Nile tilapia Oreochromis niloticus (L.) by photoperiod manipulation. Aquaculture, 243, 229-239.

Boeuf G, Le Bail P-Y (1999) Does light have an influence on fish growth? Aquaculture, 177, 129-152.

Bromage N, Porter M, Randall C (2001) The environmental regulation of maturation in farmed finfish with special reference to the role of photoperiod and melatonin. Aquaculture, 197, 63-98.

Bromage NR, Elliott JAK, Springate JRC, Whitehead C (1984) The effects of constant photoperiods on the timing of spawning in the rainbow trout. Aquaculture, 43, 213223.

Campos-Mendoza A, McAndrew BJ, Coward K, Bromage N (2004) Reproductive response of Nile tilapia (Oreochromis niloticus) to photoperiodic manipulation; effects on spawning periodicity, fecundity and egg size. Aquaculture, 231, 299-314.

Coward K, Bromage NR (2000) Reproductive physiology of female tilapia broodstock. Reviews in Fish Biology and Fisheries, V10, 1-25.

Coward K, Bromage NR, Little DC (1998) Inhibition of spawning and associated suppression of sex steroid levels during confinement in the substrate-spawning Tilapia zillii. Journal of Fish Biology, 52, 152-165.

De Lapeyre BA, Müller-Belecke A, Hörstgen-Schwark G (2009) Control of spawning activity in female Nile tilapia (Oreochromis niloticus) (L.) by temperature manipulation. Aquaculture Research, 40, 1031-1036.

El-Sayed A-FM, Kawanna M (2007) Effects of photoperiod on growth and spawning efficiency of Nile tilapia (Oreochromis niloticus L.) broodstock in a recycling system. Aquaculture Research, 38, 1242-1247.

El-Sayed A-FM, Mansour CR, Ezzat AA (2005) Effects of dietary lipid source on spawning performance of Nile tilapia (Oreochromis niloticus) broodstock reared at different water salinities. Aquaculture, 248, 187-196.

Jalabert B, Zohar Y (1982) Reproductive physiology in cichlid fishes, with particular references to Tilapia and Sarotherodon. In: The Biology and Culture of Tilapia. ICLARM conference proceedings 7 (eds Pullin RSV, Lowe-McConnell RH). ICLARM, Manila, pp. 129-140.

Okuzawa K, Furukawa K, Aida K, Hanyu I (1989) Effects of photoperiod and temperature on gonadal maturation, and plasma steroid and gonadotropin levels in a cyprinid fish, the honmoroko Gnathopogon caerulescens. General and Comparative Endocrinology, 75, 139-147.

Pankhurst NW, Purser GJ, Van Der Kraak G, Thomas PM, Forteath GNR (1996) Effect of holding temperature on ovulation, egg fertility, plasma levels of reproductive hormones and in vitro ovarian steroidogenesis in the rainbow trout Oncorhynchus mykiss. Aquaculture, 146, 277-290.

Ridha MT, Cruz EM (1999) Effect of different broodstock densities on the reproductive performance of Nile tilapia, Oreochromis niloticus (L.), in a recycling system. Aquaculture Research, 30, 203-210.

Ridha MT, Cruz EM (2000) Effect of light intensity and photoperiod on Nile tilapia Oreochromis niloticus L. seed production. Aquaculture Research, 31, 609-617. 
Srisakultiew P, Wee KL (1988) Synchronous spawning of Nile Tilapia through hypophysation and temperature manipulation. In: The Second International Symposium on Tilapia in Aquaculture (ed Pullin RSV, Bhukaswan, T., Toguthai, K. and Maclean, J.L.). Department of Fisheries, Bangkok, Thailand and International Center for Living Aquatic Resources and Management, Manila, Philippines, ICLARM conference proceedings Bangkok, Thailand, pp 275-284

Terkatin-Shimony A, Ilan Z, Yaron Z, Johnson DW (1980) Relationship between temperature, ovarian recrudescence, and plasma cortisol level in Tilapia aurea (Cichlidae, Teleostei). General and Comparative Endocrinology, 40, 143-148.

Tessema M, Muller-Belecke A, Horstgen-Schwark G (2006) Effect of rearing temperatures on the sex ratios of Oreochromis niloticus populations. Aquaculture, 258, 270-277. 


\section{Chapter 4}

\section{INFLUENCE OF A \\ REPEATED STOCKING DENSITY TREATMENT \\ ON THE SPAWNING OF FEMALE \\ NILE TILAPIA (OREOCHROMIS NILOTICUS) \\ IN A RECIRCULATING SYSTEM}

Boris Adrien de Lapeyre*, Andreas Müller-Belecke, Gabriele Hörstgen-Schwark

Institute of Animal Husbandry and Genetics, Albrecht-Thaer-Weg 3,

D-37075 Göttingen, Germany 


\section{Abstract}

Nile tilapia spawners were subjected thrice to a repeated stocking density treatment. During this experiment, 72 females were moved at weekly intervals from a high density group at $25.3 \mathrm{~kg} \mathrm{~m}^{-3}$ to single compartments at $5.6 \mathrm{~kg} \mathrm{~m}^{-3}$. The control females were moved once and maintained in groups of 12. The spawning rate calculated for a 5-day period was $25.0 \%$ in repeat $1,26.3 \%$ in repeat 2 and $38.8 \%$ in repeat 3 , which was significantly higher than in the control at 17.7\%. As egg quality parameters, the hatching rate and percentage of swim-up fry were not sigificantly different between eggs fertilized in repeat 3 and the control. Tagging indicated the presence of females with a first spawning event in each repeat $(25.0 \%, 15.2 \%, 12.5 \%)$. Furthermore, from the first to the third spawning event, the proportion of females that spawned sucessively decreased $(52.7 \%, 30.5 \%, 6.9 \%)$. At the same time there was an increase in the hatching rates $(43.8 \%, 58.2 \%$, and $64.6 \%)$ and the percentage of swim-up fry $(40.8 \%$, $54.5 \%$, and $62.0 \%)$ from eggs collected from females in their first to their third spawning event respectively. Oreochromis niloticus females responded positively to the treatment with ameliorating spawning rates and egg quality parameters.

Keywords: Oreochromis niloticus, spawning, repeated, stocking density

\section{Introduction}

Rearing Nile tilapia in intensive recirculating systems is gaining in importance. Due to the nature of recirculating systems, holding spaces are costly and must be properly managed. Under such restricted conditions, a method for performing systematic matings such as for breeding programs would greatly benefit the intensive aquaculture of Nile tilapia. Groups of males and females would have to be stripped separately of their sperm and eggs which could than be artificialy fertilized and incubated. Though harvesting sperm from the males is relatively straighforward, in the females the asynchronous nature of their ovarian cycle (Jalabert \& Zohar 1982)must be overcome. Environmental and social factors are known to have an effect on the reproduction of tilapiines, influencial factors such as photoperiod (Ridha \& Cruz 2000; Campos-Mendoza et al. 2004; Biswas et al. 2005), temperature (Srisakultiew \& Wee 1988; Coward et al. 1998; 
De Lapeyre et al. 2009), stocking density (Srisakultiew \& Wee 1988; Coward et al. 1998; Ridha \& Cruz 1999) and diet (El-Sayed et al. 2005) have been used to condition O. niloticus and Tilapia zillii (Gervais). Few experiments are known to have been performed using environmental and social factors to condition the reproduction of $O$. niloticus females held in recirculating systems. In previous research stocking density and photoperiod were tested for their ability to induce a maximim number of Nile tilapia females to spawn at one time (De Lapeyre et al., in press). It was shown that reducing the stocking density of $O$. niloticus females increased the number of strippable fish compared to the control. Moving the fish from a high density group to individual compartments induced significantly higher spawning rates than in the control. Combining a stocking density treatment with a photoperiod manipulation yielded yet higher spawning rates. However, egg quality parameters were significantly lower than in the control. Consequentily as the induced spawning rate and egg quality were promising after changing the stocking density alone, the following experiment was set up. The aim was to determine the effect of subjecting the females to repeated stocking density treatment as opposed to a one-time treatment. In this experiment, 72 females were subjected in a weekly rhythm to a reduction in stocking density from a crowded tank to individual compartments. This treatment was repeated three times. A basic question to answer was how the females, with attention to their spawning rates and reproductive parameters, reacted to the recuring treatment. Each female was tagged to follow their spawning behaviour from treatment to treatment, allowing the proportion of females that responded in each repeat of the treatment to be analysed.

\section{Materials and method}

\section{Fish}

The experiment was performed with male and female Oreochromis niloticus of the Lake Manzala population (Wessels \& Hörstgen-Schwark 2007). Each fish was tagged and had not experienced any form of treatment before these experiments. 


\section{Recirculation system}

The fish were kept at the warm water recirculation system of the Institute of Animal Husbandry and Genetics, University of Göttingen. Water parameters were within the following range: temperature $28 \pm 0.5^{\circ} \mathrm{C}$; oxygen $>7 \mathrm{mg} \mathrm{L}^{-1} ; \mathrm{pH} 6.5-7.5 ; \mathrm{NH}_{4}^{+}<0.1 \mathrm{mg}$ $\mathrm{L}^{-1} ; \mathrm{NO}_{2}^{-}<0.4 \mathrm{mg} \mathrm{L}^{-1}$. In the research facility the light was turned on at 3 am daily for a photoperiod of 12 hours. One fibreglass tank of $0.8 \mathrm{~m}-3$ capacity was connected to the recirculation system to maintain all the spawners in one single group for seven days. Six glass aquaria (volume; $0.3 \mathrm{~m}^{-3}$ ) were connected to the recirculation system of the research facility for the observation of the fish during their spawning phase. These aquaria were set up in an array of 3 groups side by side, each group consisting of 2 superposed aquaria. Furthermore, every aquarium was subdivided into 6 compartments, each with a volume of $50 \mathrm{~L}$. This was done in order to stock the females individually during the spawning phase. The sexes were kept seperately without any visual or auditory contact but were in contact through the water of the recirculation system.

\section{Repeated stocking density treatment}

Two replicates consisting of 36 females each were held for 7 days in the $0.8 \mathrm{~m}^{-3}$ fibreglass tanks at a stocking density of $25.3 \mathrm{~kg} \mathrm{~m}^{-3}$ before being moved to single compartments in the $0.3 \mathrm{~m}^{-3}$ aquaria for 7 days at a stocking density of $5.6 \mathrm{~kg} \mathrm{~m}^{-3}$ with a ratio of stocking densities of 4.5: 1.0. The same spawners were then transferred back to the fibreglass tank $\left(0.8 \mathrm{~m}^{-3}\right)$ and kept for 7 days at higher density $\left(25.3 \mathrm{~kg} \mathrm{~m}^{-3}\right)$ before being once more moved to the single compartments for a further 7 day period. Using the same fish, this procedure was repeated three times as: repeat 1 , repeat 2 , and repeat 3 . During each new stocking in the aquaria, females were randomly assigned to the compartments. The experiment was replicated twice with different fish.

\section{Control}

A procedure developed at the institute for obtaining eggs from the females in the recirculation system (De Lapeyre, Müller-Belecke \& Hörstgen-Schwark 2010) was used as the control. This method involved moving a random sample of 48 fish from a group of females held in a $1.0 \mathrm{~m}^{-3}$ fibreglass tank to the $0.3 \mathrm{~m}^{-3}$ glass aquaria. The females were kept for 7 days at a stocking-density of $47.7 \mathrm{~kg} \mathrm{~m}^{-3}$ in the fibreglass tank before 
being transferred to the glass aquaria, where they were maintained in groups of 12 for a further 7 days (stocking-density: $13.8 \mathrm{~kg} \mathrm{~m}^{-3}$ ). The stocking density expressed as a ratio before and after transfer was 3.4:1.0. This was replicated under the same conditions twice with different fish.

\section{Stripping and fertilization of eggs}

During the time the females were maintained in the aquaria, they were checked for signs of spawning twice daily from 09:00 hours till 10:00 hours and from noon to 13:00 hours. It was possible to strip most females in the period from noon to 13:00 hours. Each female was observed for signs of a red and distended urogenital papilla, a swollen abdomen, or a change of body colour to red. If this was observed, the female was removed from its aquarium and anaesthetized with clove oil (4 drops per litre) before being weighed. By gently massaging the ventral area of the female spawner, the eggs were harvested and at the same time placed in $0.9 \%$ saline solution before being counted. The males were stripped in the same way as the females but the sperm was collected with a pipette. Two random samples of 100 eggs from each batch of eggs were kept in incubation glasses $(0.02 \mathrm{~L})$ and were fertilized with mixed sperm from 3 males. The inseminated eggs were then incubated at $28^{\circ} \mathrm{C}$. All spawns were recorded but not were all fertilizable, for example when the female had already spawned before egg collection. The hatching rate was calculated by counting the number of larvae four days after fertilization (number of hatched eggs / number of fertilized eggs x 100), and the swim-up rate by counting the the number of swim-up fry (number of swim up fry / number of fertilized eggs x 100). Also the relative fecundity of the female breeder was obtained by dividing the number of eggs collected from a female by its body weight in grams.

\section{Data analysis}

The spawning rate $\left(S_{5}\right)$ was defined as the percentage of the total number of females which spawned over a period of 5 days. Similarly, the daily spawning rate $\left(S_{1}\right)$ was defined as the percentage of the total number of females which spawned on each of the observation days. Spawning rates were statistically analysed by Pearson's $\chi^{2}$ test $(2 \times 2$ contingency table) at the $5 \%$ level of significance, while mean values of the number of 
eggs per female, relative fecundity, hatching rate and percentge of swim-up fry were compared by the t-test at the 5\% level of significance. The software package SPSS was used for all statistical analysis. No significant difference in spawning rates between each replicate of the control $(\mathrm{N}=48)$ or the repeated treatment $(\mathrm{N}=36)$ was shown. Likewise, the mean values of the weight of the females, the number of eggs per female, relative fecundity, hatching and swim-up rates did not differ between these replicates. The results obtained from the repeats were summed over both replicates. Differences in spawning rates and means of the weight of the females, the number of eggs per female, relative fecundity, hatching and swim-up rates between the control $(\mathrm{N}=96)$ and experimental groups $(\mathrm{N}=72)$ were analysed. 
Figure 1: Daily spawning rates over the 5-day spawning period

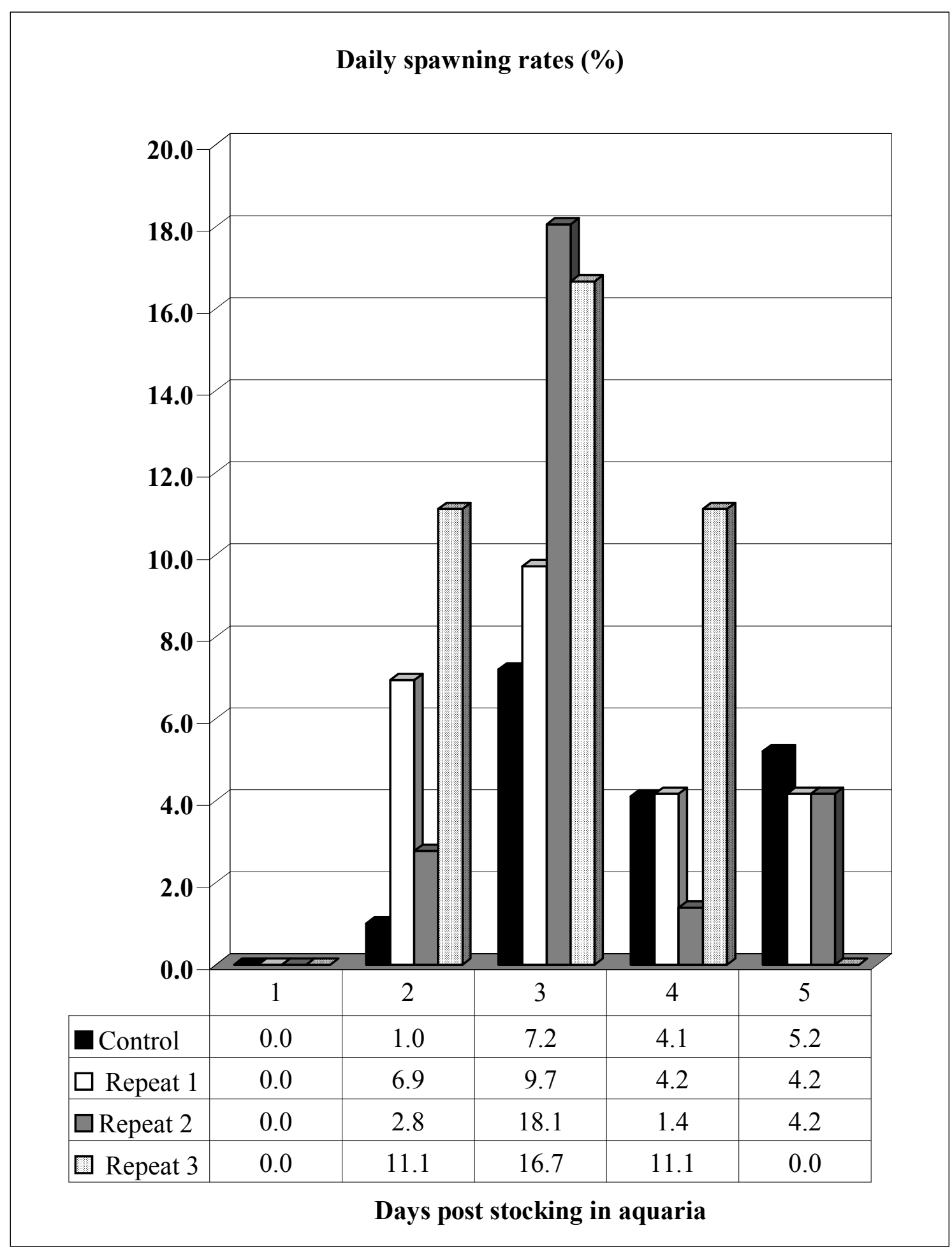


Table 1: Mean values and standard deviations (in brackets) of reproductive parameters in repeat 1, 2 and 3 for a 5 -day spawning period

\begin{tabular}{|c|c|c|c|c|c|}
\hline $\begin{array}{l}\text { Reproductive } \\
\text { Parameters }\end{array}$ & & Control & Repeat 1 & Repeat 2 & Repeat 3 \\
\hline $\mathrm{n}$ females & & 96 & 72 & 72 & 72 \\
\hline Spawns & $\mathrm{N}$ & 17 & 18 & 19 & $28^{1}$ \\
\hline Spawns fertilized & $\mathrm{N}$ & 12 & 7 & 10 & 20 \\
\hline Spawning rate $\%$ & & 17.7 & 25.0 & 26.3 & $38.8^{1}$ \\
\hline $\begin{array}{l}\text { Number of eggs } \\
\text { per female }\end{array}$ & $\begin{array}{l}\bar{X} \\
(s)\end{array}$ & $\begin{array}{l}1256.4 \\
(485.9)\end{array}$ & $\begin{array}{c}909.4 \\
(309.6)\end{array}$ & $\begin{array}{c}901.0 \\
(281.1)\end{array}$ & $\begin{array}{l}1186.2 \\
(422.5)\end{array}$ \\
\hline $\begin{array}{l}\text { Weight of } \\
\text { Females }\end{array}$ & $\begin{array}{l}\bar{X} \\
(s)\end{array}$ & $\begin{array}{l}328.6 \\
(51.7)\end{array}$ & $\begin{array}{c}280.2 \\
(105.1)\end{array}$ & $\begin{array}{c}253.2 \\
(246.1)\end{array}$ & $\begin{array}{c}287.7 \\
(101.2)\end{array}$ \\
\hline $\begin{array}{l}\text { Relative Fecundity } \\
\text { (Eggs per gram body } \\
\text { weight)) }\end{array}$ & $\begin{array}{l}\bar{X} \\
(s)\end{array}$ & $\begin{array}{l}3.8 \\
(1.3)\end{array}$ & $\begin{array}{c}3.3 \\
(0.8)\end{array}$ & $\begin{array}{c}4.8 \\
(1.7)\end{array}$ & $\begin{array}{c}4.3 \\
(1.4)\end{array}$ \\
\hline Hatching rate $\%$ & $\begin{array}{l}\bar{X} \\
(s)\end{array}$ & $\begin{array}{l}67.0 \\
(15.4)\end{array}$ & $\begin{array}{l}37.8^{2} \\
(24.3)\end{array}$ & $\begin{array}{l}44.7^{2} \\
(11.0)\end{array}$ & $\begin{array}{c}57.2 \\
(19.9)\end{array}$ \\
\hline Swim-up fry $\%$ & $\begin{array}{l}\bar{X} \\
(s)\end{array}$ & $\begin{array}{c}62.3 \\
(15.2)\end{array}$ & $\begin{array}{l}32.5^{2} \\
(24.0)\end{array}$ & $\begin{array}{l}42.4^{2} \\
(10.5)\end{array}$ & $\begin{array}{c}54.5 \\
(18.4)\end{array}$ \\
\hline
\end{tabular}

\section{Results}

\section{Repeat 1, 2 and 3}

Figure 1 shows the distribution of daily spawning rates $\left(S_{1}\right)$ of repeats 1-3 and the control calculated for the five day period after individual stocking in aquaria. No fish was observed to spawn immediately one day after transfer, day 1, in any group and on day 5 of repeat 3 . In both the experimental groups and the control, the highest daily spawning rate was observed 3 days after transfer. On this day, the $S_{l}$ values were highest in repeat $2(18.1 \%)$, lowest in repeat $1(9.7 \%)$ and reached $16.7 \%$ in repeat 3 , while the control value was the lowest at $7.2 \%$. The reproductive parameters calculated 
for the five day spawning period are given in table 1 . The spawning rate, $S_{5}$, for this period was higher in the experimental groups (repeat 1: $25.0 \%$, repeat 2: $26.3 \%$, repeat 3: $38.8 \%)$ than in the control $(17.7 \%)$ but only significantly higher in repeat 3 . The weight of the control females was higher $(328.6 \mathrm{~g})$ than in repeat $1(280.2 \mathrm{~g})$, repeat 2 $(253.2 \mathrm{~g})$ and repeat $3(287.7 \mathrm{~g})$ but this difference was not significant. The relative fecundity was highest in repeat $2,4.8 \mathrm{eggs}^{-1}$ and lowest in repeat $1,3.3 \mathrm{eggs} \mathrm{g}^{-1}$. However, no significant difference was calculated between experimental groups and control. The parameters of hatching rate and percentage of swim-up fry respectively were significantly lower in repeat $1(37.8 \%, 32.5 \%)$ and $2(44.7 \%, 42.4 \%)$ than in the control $(67.0 \%, 62.3 \%)$, while this difference was not significant for repeat $3(57.2 \%$, $54.5 \%)$.

\section{Spawner types}

Marking each fish made it possible to distinguish which fish did not spawn or spawned a first, second or third time during the duration of the experiment. Figure 2 illustrates the proportion of spawning events by type over a 5-day spawing period from repeat 1 to 3. It was observed that females with the first spawning event were present in each of the 3 repeats (repeat 1: $25.0 \%$, repeat 2: 15.2\%, repeat 3: 12.5\%). Some of the fish spawned a second time: $11.1 \%$ of the females in repeat 2 and $19.4 \%$ in repeat 3 . In repeat 3 the second spawning event is further subdivided into a first group of $11.1 \%$, which spawned for the first time in repeat 1 , and a second group of $8.3 \%$, which spawned the first time in repeat 2. A smaller proportion of $6.9 \%$ of the females spawned a third time in repeat 3.

The mean values of the reproductive parameters were calculated in table 2 for the batches of eggs fertilized from females with first, second and third spawning events. The spawning rates were calculated to be $52.7 \%, 30.5 \%$ and $6.9 \%$ respectively. The females which spawned for the third time were heavier (402.0g) than in the control (328.6g) but this difference was not significant. From the first to the third spawning event most reproductive parameters showed an improvement. The mean number of eggs per female was 929.7 eggs for the first time spawners, 1163.7 eggs for the second time spawners and 1566.3 eggs for the third time spawners. Following the same trend were the mean hatching rates $(43.8 \%, 58.2 \%$, and $64.6 \%)$ and the percentage of swim-up fry 
$(40.8 \%, 54.5 \%$, and $62.0 \%)$. Compared to the control values, the number of eggs per female (927.7 eggs), the hatching rate $(43.8 \%)$ and percentage of swim-up fry $(40.8 \%)$ were only significantly lower in the group with the first spawning event compared to the control (1256.4 eggs, $67.0 \%, 62.3 \%$ respectively). 
Figure 2: Proportion of different spawner types by order $^{1}$ of spawning events in repeats 1, 2 and 3 for a 5-day spawning period

\section{Repeat 1}
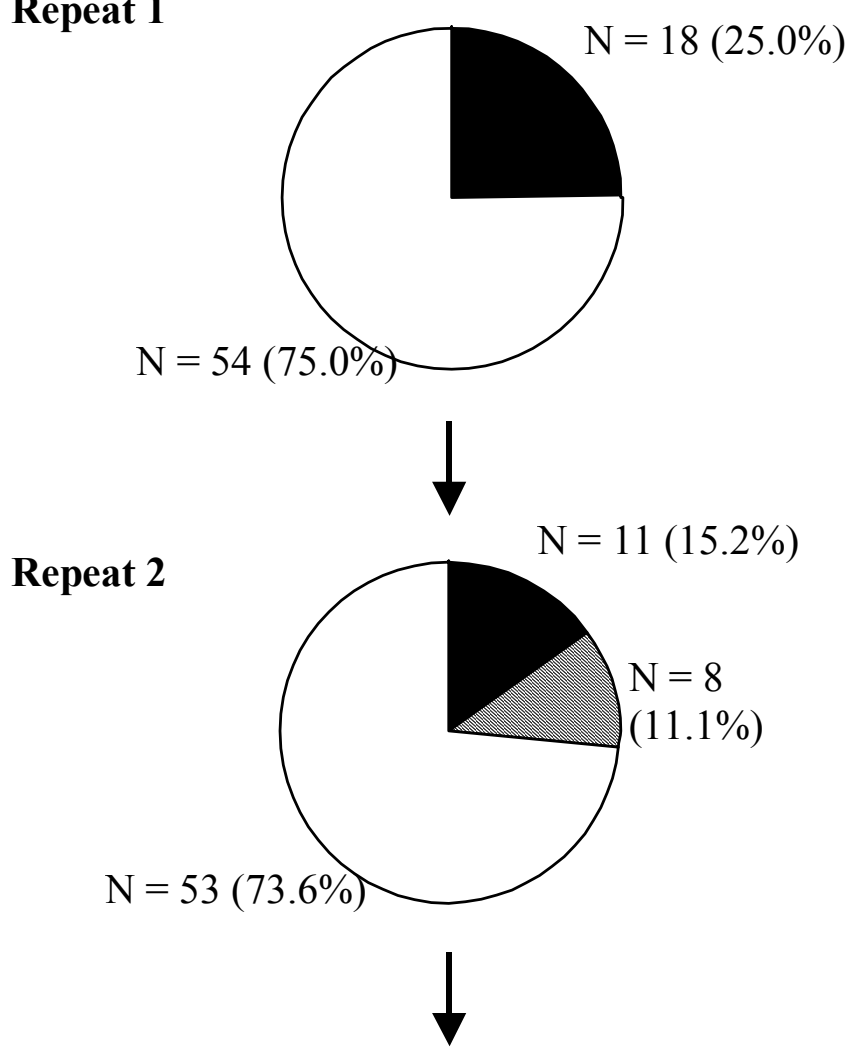

Repeat 3

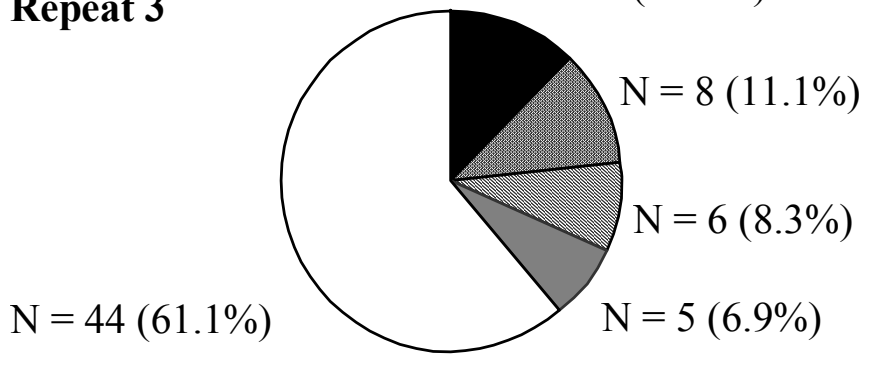

Female type:

First spawning event

Not spawned
Female type:

First spawning event

Second spawning event

$\square$ Not spawned

Female type:

First spawning event

$\square$ Second spawning event $^{2}$

四 Second spawning event $^{3}$

$\square$ Third spawning event

$\square$ Not spawned

${ }^{1}$ Spawning events during duration of experiment

${ }^{2}$ First spawning event in repeat 1

${ }^{3}$ First spawning event in repeat 2 
Table 2: Mean values and standard deviations (in brackets) of reproductive parameters by order ${ }^{1}$ of spawning events for a 5-day spawning period

\begin{tabular}{|c|c|c|c|c|c|}
\hline $\begin{array}{l}\text { Reproductive } \\
\text { parameters }\end{array}$ & & Control & $\begin{array}{c}\text { First spawning } \\
\text { event }\end{array}$ & $\begin{array}{l}\text { Second } \\
\text { spawning } \\
\text { event }\end{array}$ & $\begin{array}{c}\text { Third } \\
\text { spawning } \\
\text { event }\end{array}$ \\
\hline $\mathrm{n}$ females & $\mathrm{N}$ & 96 & 72 & 72 & 72 \\
\hline Spawns & $\mathrm{N}$ & 17 & $38^{2}$ & 22 & $5^{2}$ \\
\hline $\begin{array}{l}\text { Spawns } \\
\text { fertilized }\end{array}$ & $\mathrm{N}$ & 12 & 21 & 13 & 3 \\
\hline $\begin{array}{l}\text { Spawning } \\
\text { rate } \%\end{array}$ & & 17.7 & $52.7^{2}$ & 30.5 & $6.9^{2}$ \\
\hline $\begin{array}{l}\text { Number of eggs } \\
\text { per female }\end{array}$ & $\begin{array}{l}\bar{X} \\
(s)\end{array}$ & $\begin{array}{l}1256.4 \\
(485.9)\end{array}$ & $\begin{array}{l}929.7^{3} \\
(274.6)\end{array}$ & $\begin{array}{l}1163.7 \\
(308.4)\end{array}$ & $\begin{array}{l}1566.3 \\
(776.3)\end{array}$ \\
\hline $\begin{array}{l}\text { Weight of } \\
\text { Female }\end{array}$ & $\begin{array}{l}\bar{X} \\
(s)\end{array}$ & $\begin{array}{l}328.6 \\
(51.7)\end{array}$ & $\begin{array}{l}272.6 \\
(156.4)\end{array}$ & $\begin{array}{l}248.8 \\
(82.4)\end{array}$ & $\begin{array}{c}402.0 \\
(159.1)\end{array}$ \\
\hline $\begin{array}{l}\text { Relative } \\
\text { fecundity } \\
\text { (Eggs per gram } \\
\text { body weight) }\end{array}$ & $\begin{array}{l}\bar{X} \\
(s)\end{array}$ & $\begin{array}{l}3.8 \\
(1.3)\end{array}$ & $\begin{array}{c}3.9 \\
(1.4)\end{array}$ & $\begin{array}{c}4.9 \\
(1.6)\end{array}$ & $\begin{array}{c}3.8 \\
(0.3)\end{array}$ \\
\hline Hatching rate $\%$ & $\begin{array}{l}\bar{X} \\
(s)\end{array}$ & $\begin{array}{l}67.0 \\
(15.4)\end{array}$ & $\begin{array}{l}43.8^{3} \\
(20.7)\end{array}$ & $\begin{array}{c}58.2 \\
(17.7)\end{array}$ & $\begin{array}{c}64.6 \\
(16.5)\end{array}$ \\
\hline Swim-up fry $\%$ & $\begin{array}{l}\bar{X} \\
(s)\end{array}$ & $\begin{array}{c}62.3 \\
(15.2)\end{array}$ & $\begin{array}{l}40.8^{3} \\
(20.8)\end{array}$ & $\begin{array}{c}54.5 \\
(15.6)\end{array}$ & $\begin{array}{c}62.0 \\
(15.0)\end{array}$ \\
\hline
\end{tabular}

${ }^{\mathrm{T}}$ Spawning events during duration of experiment

${ }^{2}$ Value significantly different to corresponding control value: $\chi^{2}$ test $(5 \%)$

${ }^{3}$ Mean significantly different to corresponding control mean: $t$ test $(5 \%)$

\section{Discussion}

Conducted the first time in repeat 1 , the change in stocking density from $25.3 \mathrm{~kg} \mathrm{~m}^{-3}$ to individual compartments at $5.6 \mathrm{~kg} \mathrm{~m}^{-3}$ induced a higher $\left(S_{5}: 25.0 \%\right)$, though not significant, spawning rate than in the control $\left(S_{5}: 17.7 \%\right)$. However, compared to previous experiments using a similar conditioning with stocking density, a higher spawning rate of $32.2 \%$ was observed which was also significantly higher than the control (De Lapeyre et al. 2010). A possible explanation lies in the ratio of stocking densities which was much higher in the latter, 7.0:1.0, as opposed to this experiment, 4.5:1.0. It is known that maintaining tilapiine females at high stocking densities halts 
their reproduction (Balarin et al. 1986). Stopping or at least halting their reproduction appears to be a prerequisite to reaching high spawning rates once the females are placed in individual compartments. Keeping the females in this experiment at a stocking density of $25.3 \mathrm{~kg} \mathrm{~m}^{-3}$ was possibly not crowded enough to stop reproduction. As it was impossible to check the females for signs of spawning while in the holding tank without overstressing them, this cannot be confirmed.

The repeated treatment of the same fish led to successively improved spawning rates from repeat to repeat $(\mathrm{S} 5: 25.0 \%, 26.3 \%, 38.8 \%)$. Only when the treatment was repeated for the third time was the difference to the control group significant. After this third treatment, the induced spawning rate was comparable to the rate observed after a one time stocking density change $\left(S_{5}: 32.2 \%\right)$ in previous experiments (De Lapeyre et al. 2010). This seems to suggest that with a repeated treatment of the same fish with a smaller change in stocking density, similar spawning rates can be expected than from females subjected to a one time but higher stocking density change.

Over the 5-day spawning period, the distibution of daily spawning rates follows an increase from day 2 to day 3 where a peak in spawning activity is observed before decreasing to day 4 and 5. Possibly as a result of the handling stress no females were ready to spawn shortly after being put in the individual compartments. This was also observed in previous tests (De Lapeyre et al. 2010). More females were ready to spawn at one time 72-80 hours after acclimatizing to their new holding space. Consistent with past trials involving stocking density, this time frame could help predict when to expect most females to spawn under the conditions of this treatment.

Egg quality parameters such as hatching rates and percentage of swim-up fry ameliorated from repeat 1 to repeat 3 . The number of eggs per female and relative fecundity, however, did not follow the same trend as they respectively decreased/ increased from repeat 1 to 2 and increased/ decreased from repeat 2 to 3 . This might due to the fact that although on average less eggs per female were obtanied in repeat 2 (901.0), the weight of the females for this group was the lowest $(253.2 \mathrm{~g})$, accounting for the highest relative fecundity of 4.8 eggs per gram body weight in repeat 2 . The range of the relative fecundity calculated for repeats 2 and 3 was $4-5$ eggs per gram, about 1 egg per gram higher than the best results obtained in previous experiments (De Lapeyre et al. 2010). This suggests that repeated treatment had a positive effect on relative 
fecundity. Hatching rates and percentage of swim-up fry calculated for repeat $3(57.2 \%$, $54.5 \%)$ were also comparable to results obtained after a one-time stocking density change $(64.0 \%, 56.4 \%)$. An experiment set up to condition the fish with water maintained at $22^{\circ} \mathrm{C}$ produced similar spawning rates (calculated for a $7 \mathrm{~d}$ spawning period) but with lower hatching rates and percentage of swim-up fry on average (De Lapeyre et al. 2009). A combination of photoperiod and stocking density treatment induced a high spawning rate (S5: 65.2\%). However, the relative fecundity, hatching rate and percentage of swim-up fry were significantly lower than the corresponding values of the control (De Lapeyre et al. 2010).

Through tagging it was possible to track the spawning participation of the females. It was found that in each repeat, a proportion of females which spawned for the first time during the experiment was present (repeat 1-3: $25.0 \%, 15.2 \%, 12.5 \%$ ). These results suggest that some females had to undergo treatment twice or even three times before they spawned for the first time in this experiment. On the other hand, the diminishing proportion of such females present from repeat 1-3 attests, with each consecutive treatment, to the effectivity of the treatment. In repeat 3 for the second time spawners, it was possible to differentiate between the females that spawned for the first time in repeat $1(11.1 \%)$ and those that spawned for the first time in repeat $2(8.3 \%)$. A possible explanation for this disparity is that the first group required more recovery time between spawnings than the second group as they did not spawn in repeat 2 while the second group did.

When following the same females that spawned a first time in repeat $1(25 \%)$, a second time in repeat $2(11 \%)$ and a third time in repeat $3(7 \%)$, a decreasing proportion of females reacting to the repeated treatment are observed. At the same time, the absolute proportion of females spawning (whether for a first, second or third time) increased from repeat 1 to repeat $3(25.0 \%, 26.3 \%, 38.8 \%)$. Thus, a decreasing spawning synchronicity of female that spawned up to three times is compensated for by the females spawning for the first or second time in repeat 2 and 3. 


\section{Conclusion}

Besides using stocking density as a factor to specifically influence the spawning of Nile tilapia females under intensive holding conditions, this experiment demonstrates how $O$. niloticus reproduction can be controlled by a repeated treatment. Both spawning rates and egg quality parameters improved at the same time at sucessive treatments of the same females. Marking the fish gave valuable information on the spawning pattern of each female. Furthermore, the short $7 d$ intervals used in the experiment is convenient for obtaining batches of eggs on a regular basis and in a predictable manner. This could be a real advantage in recirculating systems as selective breeding can be better planned and implemented with this method.

\section{Acknowledgements}

This work was supported by the Ministry for Science and Culture of Lower Saxony within the scope of a German-Israeli partnership. 


\section{References}

Balarin JD, Haller RD, Armitage AT (1986) Research on Intensive Culture of Tilapia in Tanks. In: Aquaculture research in the Africa region: proceedings of the African Seminar on Aquaculture, organised by the International Foundation for Science (IFS), Stockholm (ed Huisman EA). Pudoc, 1986, Wageningen, pp. 206-216.

Biswas AK, Morita T, Yoshizaki G, Maita M, Takeuchi T (2005) Control of reproduction in Nile tilapia Oreochromis niloticus (L.) by photoperiod manipulation. Aquaculture, 243, 229-239.

Campos-Mendoza A, McAndrew BJ, Coward K, Bromage N (2004) Reproductive response of Nile tilapia (Oreochromis niloticus) to photoperiodic manipulation; effects on spawning periodicity, fecundity and egg size. Aquaculture, 231, 299314.

Coward K, Bromage NR, Little DC (1998) Inhibition of spawning and associated suppression of sex steroid levels during confinement in the substrate-spawning Tilapia zillii. Journal of Fish Biology, 52, 152-165.

De Lapeyre BA, Müller-Belecke A, Hörstgen-Schwark G (2009) Control of spawning activity in female Nile tilapia (Oreochromis niloticus) (L.) by temperature manipulation. Aquaculture Research, 40, 1031-1036.

De Lapeyre BA, Müller-Belecke A, Hörstgen-Schwark G (2010) Increased spawning activity of female Nile tilapia (Oreochromis niloticus) (L.) after stocking density and photoperiod manipulation. Aquaculture Research.

El-Sayed A-FM, Mansour CR, Ezzat AA (2005) Effects of dietary lipid source on spawning performance of Nile tilapia (Oreochromis niloticus) broodstock reared at different water salinities. Aquaculture, 248, 187-196.

Jalabert B, Zohar Y (1982) Reproductive physiology in cichlid fishes, with particular references to Tilapia and Sarotherodon. In: The Biology and Culture of Tilapia. ICLARM conference proceedings 7 (eds Pullin RSV, Lowe-McConnell RH). ICLARM, Manila, pp. 129-140.

Ridha MT, Cruz EM (1999) Effect of different broodstock densities on the reproductive performance of Nile tilapia, Oreochromis niloticus (L.), in a recycling system. Aquaculture Research, 30, 203-210.

Ridha MT, Cruz EM (2000) Effect of light intensity and photoperiod on Nile tilapia Oreochromis niloticus L. seed production. Aquaculture Research, 31, 609-617.

Srisakultiew P, Wee KL (1988) Synchronous spawning of Nile Tilapia through hypophysation and temperature manipulation. In: The Second International Symposium on Tilapia in Aquaculture (ed Pullin RSV, Bhukaswan, T., Toguthai, K. and Maclean, J.L.). Department of Fisheries, Bangkok, Thailand and International Center for Living Aquatic Resources and Management, Manila, Philippines, ICLARM conference proceedings Bangkok, Thailand, pp 275-284

Wessels S, Hörstgen-Schwark G (2007) Selection experiments to increase the proportion of males in Nile tilapia (Oreochromis niloticus) by means of temperature treatment Aquaculture, 272, S80-S87 
Chapter 5

GENERAL DISCUSSION 
The findings from chapters 2, chapter 3 and chapter 4 are discussed here. For comparison purposes, the spawning phase of the temperature experiments is calculated for a 5-day instead of a 7-day period; consequently, slightly different results than in chapter 2 are obtained.

In the first part of this chapter, the spawning activity of the females during the spawning phase of all experiments is explored. Furthermore, spawning rates and reproduction parameters summarised over the same period are compared. All factors tested are discussed in the second part of this chapter.

\section{Part I}

The conditions under which all seven experiments were kept are summarized in table 1, with respect to the number of spawners used in each phase. Experiments 1,2 and 3 were discussed prior to this one in chapter 2, experiments 4, 5, 6 in chapter 3 and experiment 7 was discussed in chapter 4 .

\section{Induced spawning rates}

The distribution of the daily spawning rates in the spawning phase of all the performed experiments are given in the following figures:

- Figure 1: experiments 1, 2 and 3 (adapted from chapter 2)

- Figure 2: experiments 4, 5 and 6 (adapted from chapter 3)

- Figure 3: experiment 4 and 7 (adapted from chapter 4)

The spawning rates on each day from day 1 to day 5 were accordingly on:

\section{Day 1}

Only in the controls of experiments 1,2 and 3 did females spawn. The spawning rates were $3 \%, 4 \%$ and $4 \%$ respectively.

\section{Day 2}

In experiments 3, 4 and 7 (repeat 2), the spawning rates were lower than $5 \%(3 \%, 1 \%$ and $3 \%$ respectively), while the spawning rates in experiment $6 \mathrm{a}$ and experiment7 (repeat 1 and repeat 3$)$ were higher than $5 \%(8 \%, 7 \%$ and $11 \%$ respectively). No 
females spawned during experiment 2, the control of experiment 3, experiment 5 or experiment $6 \mathrm{~b}$.

Table 1: Number of females in treatment groups (TG) and control (C) in all experiments

\begin{tabular}{|c|c|c|c|c|}
\hline Trial & & $\begin{array}{c}\text { Acclimatisation } \\
\text { Phase }\end{array}$ & $\begin{array}{c}\text { Treatment } \\
\text { Phase }\end{array}$ & $\begin{array}{c}\text { Spawning } \\
\text { Phase }\end{array}$ \\
\hline \multirow{3}{*}{$\begin{array}{l}\text { Experiment } 1 \\
\text { Temperature } 22^{\circ} \mathrm{C} \text { for a } 28 \text {-day } \\
\text { period and group stocking }\end{array}$} & Duration in days & 7-day & 28-day & 5-day \\
\hline & TG: $\mathrm{n}$ females & 96 & 96 & 96 \\
\hline & $\mathrm{C}: \mathrm{n}$ females & 72 & 72 & 72 \\
\hline \multirow{3}{*}{$\begin{array}{l}\text { Experiment } 2 \\
\text { Temperature } 22^{\circ} \mathrm{C} \text { for a } 14 \text {-day } \\
\text { period and individual stocking }\end{array}$} & Duration in days & 7-day & 14-day & 5-day \\
\hline & TG: $\mathrm{n}$ females & 48 & 48 & 48 \\
\hline & $\mathrm{C}: \mathrm{n}$ females & 24 & 24 & 24 \\
\hline \multirow{3}{*}{$\begin{array}{l}\text { Experiment } 3 \\
\text { Temperature } 22^{\circ} \mathrm{C} \text { for a } 7 \text {-day } \\
\text { period and group stocking }\end{array}$} & Duration in days & 7-day & 7-day & 5-day \\
\hline & TG: $\mathrm{n}$ females & 60 & 60 & 60 \\
\hline & $\mathrm{C}: \mathrm{n}$ females & 48 & 48 & 48 \\
\hline \multirow{2}{*}{$\begin{array}{l}\text { Experiment 4: } \\
\text { Control for experiment } 5,6 \text { and } 7 \text {. } \\
\text { Stocking density change to group } \\
\text { stocking (ratio of stocking density } \\
3: 1 \text { ) }\end{array}$} & Duration in days & - & 7-day & 5-day \\
\hline & $\mathrm{n}$ females & - & 96 & 96 \\
\hline \multirow{2}{*}{$\begin{array}{l}\text { Experiment 5: } \\
\text { Stocking density change to single } \\
\text { stocking (ratio of stocking density } \\
7: 1 \text { ) }\end{array}$} & Duration in days & - & 7-day & 5-day \\
\hline & $\mathrm{n}$ females & - & 96 & 96 \\
\hline \multirow{2}{*}{$\begin{array}{l}\text { Experiment 6a } \\
\text { Photoperiod of } 6 \mathrm{~L}: 18 \mathrm{D} \text { for a } 21- \\
\text { day period followed by a } \\
\text { stocking density change to single } \\
\text { stocking (ratio of stocking density } \\
4: 1 \text { ) }\end{array}$} & Duration in days & - & 7-day & 5-day \\
\hline & $\mathrm{n}$ females & - & 72 & 72 \\
\hline \multirow{2}{*}{$\begin{array}{l}\text { Experiment 6b } \\
\text { Photoperiod of } 6 \mathrm{~L}: 18 \mathrm{D} \text { for a } 28- \\
\text { day period followed by a stocking } \\
\text { density change to single stocking } \\
\text { (ratio of stocking density } 4: 1 \text { ) }\end{array}$} & Duration in days & - & 7-day & 5-day \\
\hline & $\mathrm{n}$ females & - & 36 & 36 \\
\hline \multirow{2}{*}{$\begin{array}{l}\text { Experiment } 7 \\
\text { Repeated stocking density change } \\
\text { to single stocking (ratio of } \\
\text { stocking density } 4: 1 \text { ) }\end{array}$} & Duration in days & - & $\overline{7-d a y}$ & 5-day \\
\hline & $\mathrm{n}$ females & - & 36 & 36 \\
\hline
\end{tabular}




\section{Day 3}

Experiment 7 (repeat 1), the controls of experiments 1, 2, 3 and in experiment 4 had spawning rates not in excess of $10 \%(10 \%, 3 \%, 8 \%, 4 \%$ and $7 \%$ respectively), while the spawning rates in experiment $1,2,3,5,6 \mathrm{a}, 6 \mathrm{~b}$, and 7 (repeat 2 and 3 ) exceeded 10\% $(18 \%, 27 \%, 13 \%, 21 \%, 44 \%, 19 \%, 18 \%$ and $17 \%$ respectively). Experiment $6 a$ had by far the highest spawning rate with a value of $44 \%$.

\section{Day 4}

In experiments 3, 4, 7 (repeats 1 and 2) and in the control of experiment 1 the spawning rates were lower than $5 \%(3 \%, 4 \%, 2 \%, 4 \%, 1 \%$ and $3 \%$ respectively), while the spawning rates in experiments $1,2,5,6 \mathrm{a}, 6 \mathrm{~b}$ and 7 (repeat 3$)$, were higher than $5 \%(6 \%$, $8 \%, 7 \%, 8 \%, 17 \%$ and $11 \%$ respectively). Experiment $6 \mathrm{~b}$ had the highest spawning rate $(17 \%)$. No females spawned in the controls of experiment 2 and experiment 3.

\section{Day 5}

In experiments $1,2,3,4,5,6 \mathrm{a}, 7$ (repeats 1 and 2) and in the control of experiment 3 the spawning rates were not in excess of $5 \%(2 \%, 4 \%, 2 \%, 5 \%, 4 \%, 4 \%, 4 \%, 4 \%$ and $2 \%$ respectively). No females spawned in the controls of experiments 1 and 2 , and in experiment $6 \mathrm{~b}$ or in experiment 7 (repeat 3 ).

The spawning rates in all control groups were relatively constant over the five day spawning period and never exceeded $10 \%$ on any day. In contrast, a characteristic pattern was observed in the treatment groups. The spawning incidence increased from day 1 to day 3 and subsequently decreased until day 5 . The highest spawning rate was observed on day 3. Furthermore the distribution of spawning rates was roughly symmetrical about day 3 . In all treated groups, except in experiment 7 - repeat $1(10 \%)$, the highest daily spawning rates recorded were all above $10 \%$ on day 3 . A 14-day temperature treatment in combination with single stocking was more effective in inducing spawning $(27 \%)$ than a 28 -day temperature treatment $(18 \%)$ or a 7 -day temperature treatment $(13 \%)$ combined with group stocking. During repeated stocking density changes (experiment 7), the spawning rate followed a trend by increasing from repeat $1(10 \%)$ to repeat $2(18 \%)$ to reach $16 \%$ in repeat 3 . On day 3 , the second highest spawning rate was observed in experiment 5 after a onetime change of stocking density 
to group stocking (ratio of stocking densities 7:1). The most successful in terms of spawning rates during an experiment was achieved with a 21-day photoperiod manipulation combined with a change in stocking density. In this experiment, $44 \%$ of the females spawned on day 3 . 


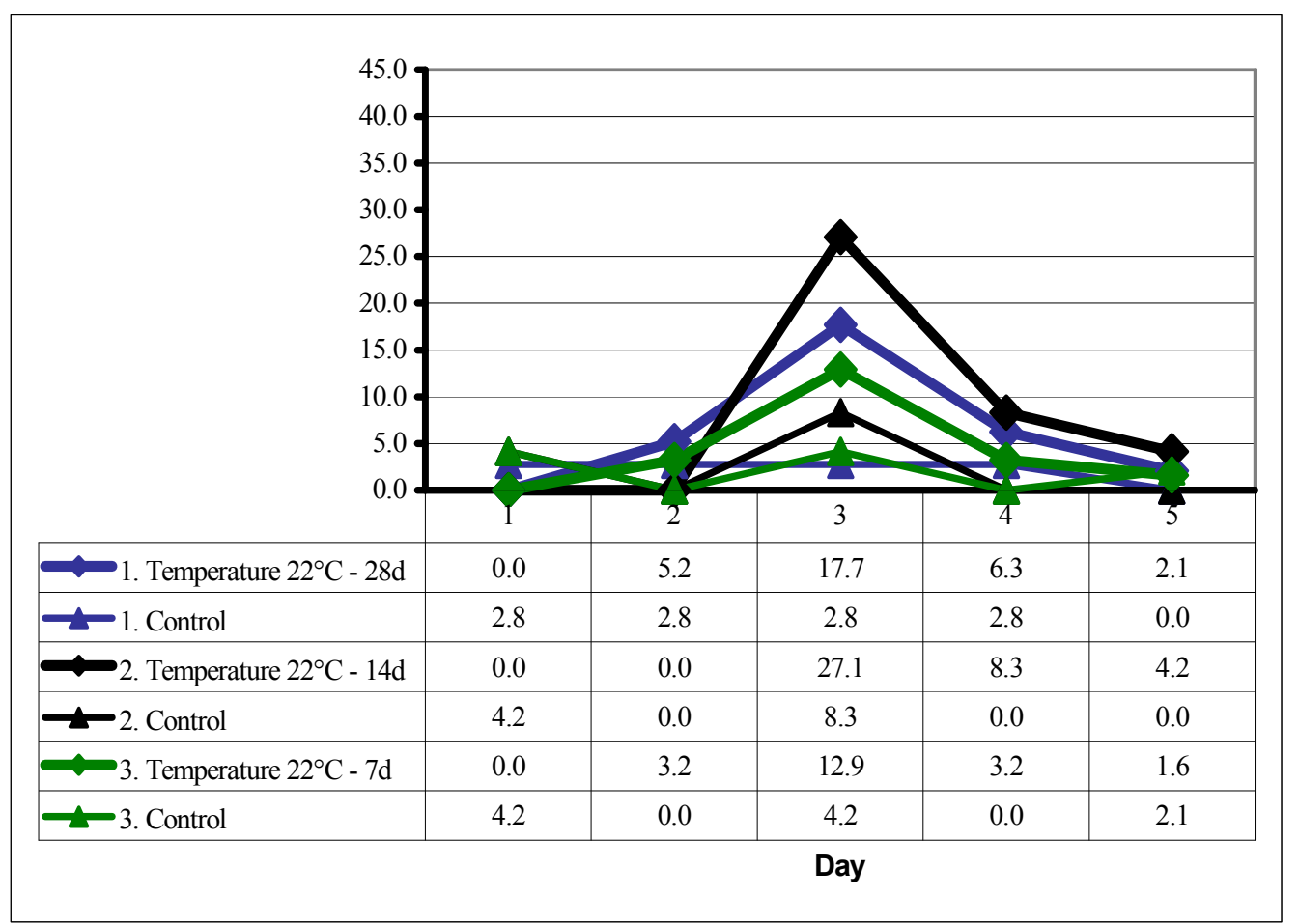

Figure 1: Spawning rates of experiments 1,2, 3 observed in a 5-day spawning period after temperature treatment

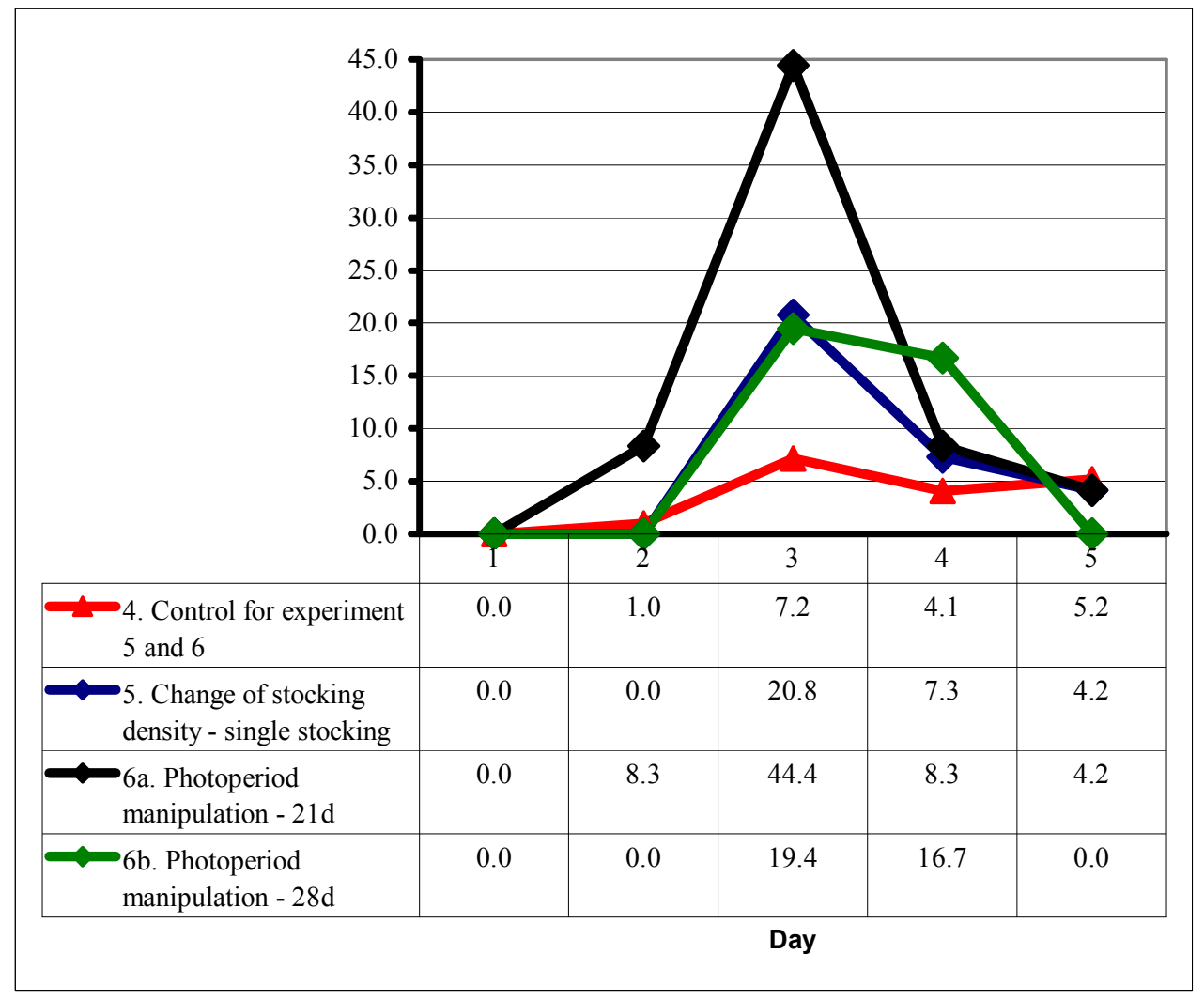

Figure 2: Spawning rates of experiment 4 (control) and experiments 5 and 6 observed in a 5-day spawning period after stocking density and photoperiod treatment 


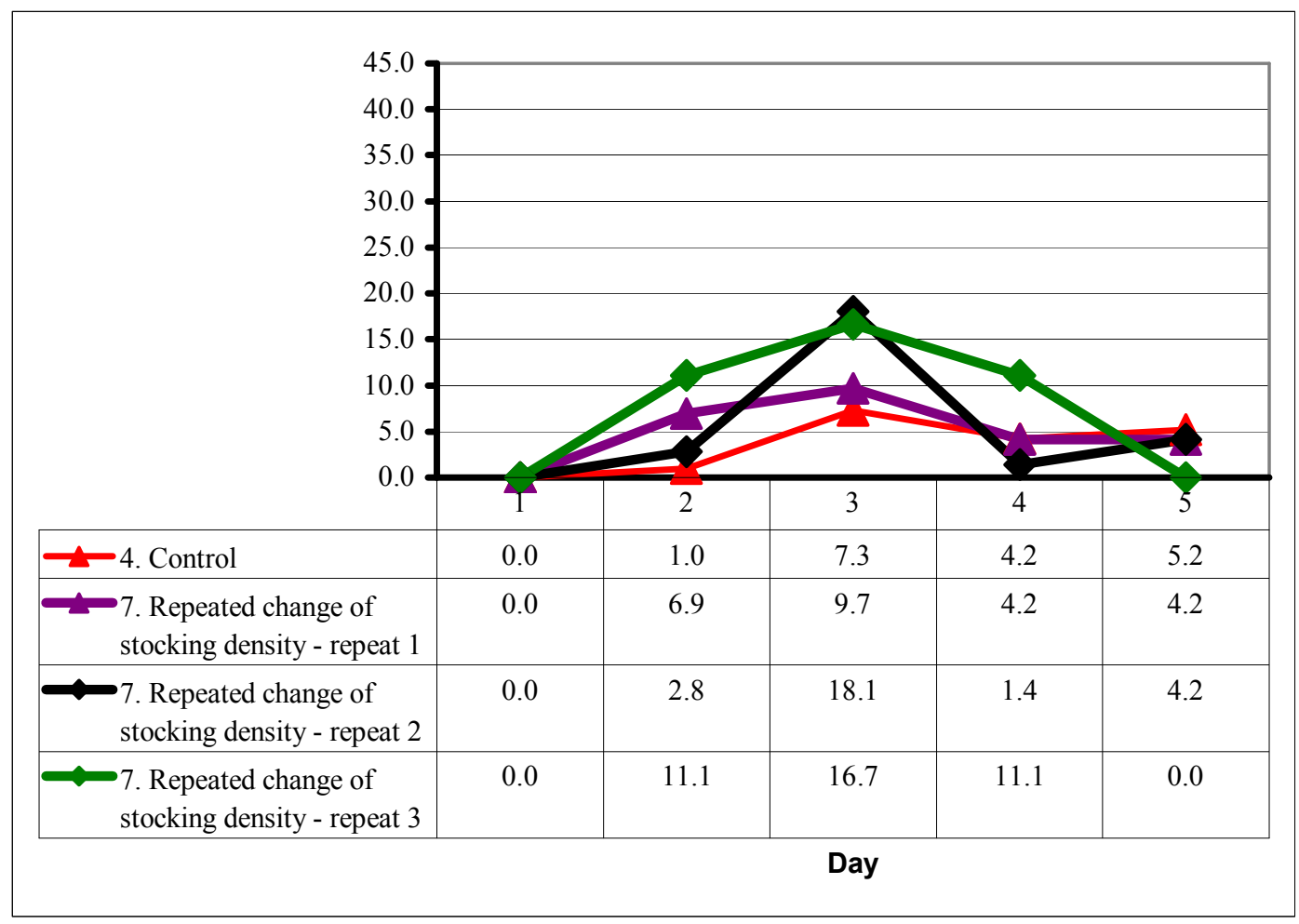

Figure 3: Spawning rates of experiment 4 (control) and experiment 7 (repeat 1, 2, 3) observed in a 5-day spawning period after stocking density treatment

\section{Egg quality}

In table 2, the egg quality parameters - number of eggs per female, relative fecundity, hatching rate (HR) and rate of swim-up fry (SR) - and total spawning rate summarised over a 5 day period are presented for all experiments.

In the $28 \mathrm{~d}$ and $14 \mathrm{~d}$ temperature treatments, the total spawning rates $(31 \%, 40 \%)$ were significantly higher than in the corresponding controls $(11 \%, 13 \%)$. At the same time the hatching and swim-up fry rates (HR: 23\%, 33\%; SR: 20\%, 29\%) were significantly lower than in the corresponding controls (HR: 58\%, 74\%; SR: 54\%, 69\%) in the same groups. Differences in mean values between the treatment and control group of the $7 \mathrm{~d}$ treatment trial were not significant. 
Table 2: Mean values and standard deviations (in brackets) of reproductive parameters in the 5 days spawning phase

\begin{tabular}{|c|c|c|c|c|c|c|c|}
\hline \multirow[t]{2}{*}{ Experiment } & & $\begin{array}{l}\text { Total } \\
\text { Spaw } \\
\text { ns }\end{array}$ & $\begin{array}{l}\text { Spaw } \\
\text { ning } \\
\text { rate } \\
\%\end{array}$ & $\begin{array}{c}\text { n eggs } \\
\text { per } \\
\text { female }\end{array}$ & $\begin{array}{l}\text { Relative } \\
\text { fecund- } \\
\text { dity* }\end{array}$ & $\begin{array}{c}\text { Hatching } \\
\text { rate } \\
\%\end{array}$ & $\begin{array}{c}\text { Swim-up } \\
\text { fry rate } \\
\%\end{array}$ \\
\hline & $\mathbf{N}$ & $\mathbf{N}$ & $\begin{array}{l}\bar{X} \\
(\mathbf{s}) \\
\end{array}$ & $\begin{array}{l}\bar{X} \\
\text { (s) } \\
\end{array}$ & $\begin{array}{l}\bar{X} \\
\text { (s) }\end{array}$ & $\begin{array}{l}\bar{X} \\
\text { (s) }\end{array}$ & $\begin{array}{l}\bar{X} \\
\text { (s) }\end{array}$ \\
\hline $\begin{array}{l}\text { 1. Temperature } \\
\left(22^{\circ} \mathrm{C}, 28 \text {-day }\right)\end{array}$ & 96 & $30^{a}$ & $31.2^{\mathrm{a}}$ & $\begin{array}{c}996.9 \\
(405.7)\end{array}$ & $\begin{array}{c}3.0 \\
(1.4)\end{array}$ & $\begin{array}{l}23.1^{\mathrm{b}} \\
(27.3)\end{array}$ & $\begin{array}{l}20.4^{b} \\
(24.8)\end{array}$ \\
\hline Control & 72 & 8 & 11.1 & $\begin{array}{l}1133.5 \\
(394.2)\end{array}$ & $\begin{array}{c}3.7 \\
(1.0)\end{array}$ & $\begin{array}{c}58.1 \\
(25.8)\end{array}$ & $\begin{array}{c}54.4 \\
(25.8)\end{array}$ \\
\hline $\begin{array}{l}\text { 2. Temperature } \\
\left(22^{\circ} \mathrm{C}, 14-d a y\right)\end{array}$ & 48 & $19^{\mathrm{a}}$ & $39.5^{\mathrm{a}}$ & $\begin{array}{l}1021.7 \\
(345.1)\end{array}$ & $\begin{array}{l}3.2^{b} \\
(1.5)\end{array}$ & $\begin{array}{l}33.3^{b} \\
(35.2)\end{array}$ & $\begin{array}{l}28.5^{b} \\
(31.0)\end{array}$ \\
\hline Control & 24 & 3 & 12.5 & $\begin{array}{l}539.3 \\
(122.9)\end{array}$ & $\begin{array}{l}1.3 \\
(0.6)\end{array}$ & $\begin{array}{l}74.0 \\
(6.9)\end{array}$ & $\begin{array}{c}69.0 \\
(10.4)\end{array}$ \\
\hline $\begin{array}{l}\text { 3. Temperature } \\
\left(22^{\circ} \mathrm{C}, 7-\text { day }\right)\end{array}$ & 60 & 13 & 21.6 & $\begin{array}{c}705.0 \\
(488.8)\end{array}$ & $\begin{array}{c}2.4 \\
(1.6)\end{array}$ & $\begin{array}{c}35.2 \\
(37.0)\end{array}$ & $\begin{array}{c}29.0 \\
(30.3)\end{array}$ \\
\hline Control & 48 & 5 & 10.4 & $\begin{array}{c}924.6 \\
(521.6)\end{array}$ & $\begin{array}{c}2.4 \\
(0.9)\end{array}$ & $\begin{array}{c}36.2 \\
(45.8)\end{array}$ & $\begin{array}{l}33.0 \\
(41.6)\end{array}$ \\
\hline $\begin{array}{l}\text { 4. Control for } \\
\text { experiment } 5,6 \text { and } \\
7\end{array}$ & 96 & 17 & 17.7 & $\begin{array}{l}1256.4 \\
(485.9)\end{array}$ & $\begin{array}{c}3.8 \\
(1.3)\end{array}$ & $\begin{array}{l}67.0 \\
(15.4)\end{array}$ & $\begin{array}{c}62.3 \\
(15.2)\end{array}$ \\
\hline $\begin{array}{l}\text { 5. Onetime change } \\
\text { of stocking density }\end{array}$ & 96 & $31^{\mathrm{a}}$ & $32.2^{\mathrm{a}}$ & $\begin{array}{l}822.7^{b} \\
(584.4)\end{array}$ & $\begin{array}{l}2.2^{b} \\
(1.6)\end{array}$ & $\begin{array}{c}64.0 \\
(22.0)\end{array}$ & $\begin{array}{c}56.3 \\
(19.3)\end{array}$ \\
\hline $\begin{array}{l}\text { 6. Photoperiod } \\
\text { manipulation - 21d }\end{array}$ & 72 & $47^{\mathrm{a}}$ & $65.2^{\mathrm{a}}$ & $\begin{array}{l}896.5^{b} \\
(320.2)\end{array}$ & $\begin{array}{l}2.6^{b} \\
(1.0)\end{array}$ & $\begin{array}{l}41.3^{b} \\
(21.5)\end{array}$ & $\begin{array}{l}40.4^{b} \\
(21.5)\end{array}$ \\
\hline $\begin{array}{l}\text { 6. Photoperiod } \\
\text { manipulation - 28d }\end{array}$ & 36 & $13^{\mathrm{a}}$ & $36.1^{\mathrm{a}}$ & $\begin{array}{r}964.2 \\
(242.3) \\
\end{array}$ & $\begin{array}{c}3.0 \\
(0.1) \\
\end{array}$ & $\begin{array}{l}54.6 \\
(26.7) \\
\end{array}$ & $\begin{array}{c}48.8 \\
(24.3) \\
\end{array}$ \\
\hline $\begin{array}{l}\text { 7. Repeated change } \\
\text { of stocking density } \\
-\quad \text { repeat } 1 \\
\end{array}$ & 72 & 18 & 25.0 & $\begin{array}{c}909.4 \\
(309.6)\end{array}$ & $\begin{array}{c}3.3 \\
(0.8)\end{array}$ & $\begin{array}{l}37.8^{b} \\
(24.3)\end{array}$ & $\begin{array}{l}32.5^{b} \\
(24.0)\end{array}$ \\
\hline $\begin{array}{l}\text { 7. Repeated change } \\
\text { of stocking density } \\
-\quad \text { repeat } 2 \\
\end{array}$ & 72 & 19 & 26.3 & $\begin{array}{c}901.0 \\
(281.1)\end{array}$ & $\begin{array}{c}4.8 \\
(1.7)\end{array}$ & $\begin{array}{l}44.7^{b} \\
(11.0)\end{array}$ & $\begin{array}{l}42.4^{b} \\
(10.5)\end{array}$ \\
\hline $\begin{array}{l}\text { 7. Repeated change } \\
\text { of stocking density } \\
-\quad \text { repeat } 3\end{array}$ & 72 & $28^{\mathrm{a}}$ & $38.8^{\mathrm{a}}$ & $\begin{array}{l}1186.2 \\
(422.5)\end{array}$ & $\begin{array}{c}4.3 \\
(1.4)\end{array}$ & $\begin{array}{c}57.2 \\
(19.9)\end{array}$ & $\begin{array}{c}54.5 \\
(18.4)\end{array}$ \\
\hline
\end{tabular}

In experiments 4, 5, 6 and 7, the total spawning rates were significantly higher in experiment $5(32 \%)$, in experiment $6 \mathrm{a}(65 \%)$, in experiment $6 \mathrm{~b}(36 \%)$ and in repeat 3 of experiment 7 (39\%) than in the control (exp. 4: 18\%). Several egg quality parameters were, however, significantly lower than in the control (1256 eggs per female, 4 eggs $\mathrm{g}^{-1}$ body weight, hatching rate $67 \%$, swim-up fry 62\%): experiment 5 (823 eggs per female, 2 eggs $\mathrm{g}^{-1}$ body), experiment $6 \mathrm{a}$ (897 eggs per female, 3 eggs $\mathrm{g}^{-1}$ body weight, hatching 
rate $41 \%$, swim-up fry $40 \%$ ), experiment 7 - repeat 1 (hatching rate $38 \%$, swim-up fry $33 \%$ ) and experiment 7 - repeat 2 (hatching rate 45\%, swim-up fry 42\%). In experiment 5 (hatching rate 64\%, swim-up fry 56\%) and in experiment $6 \mathrm{~b}$ (964 eggs per female, 3 eggs $\mathrm{g}^{-1}$ body weight, hatching rate 55\%, swim-up fry $49 \%$ ) no significant difference in mean values of these parameters was observed. In general, the standard deviation tended to be larger in temperature treated fish than in the other experiments.

\section{Part II}

\section{Effect of reduced water temperature}

A water temperature of $22^{\circ} \mathrm{C}$ for 28 days (experiment 1 ), 14 days (experiment 2) and 7 days (experiment 3 ) effectively suppressed spawning as less than $5 \%$ of females (14days and 28-day treatment) or no females (7-day treatment) spawned while the water temperature was maintained at $22^{\circ} \mathrm{C}$. While it is documented that temperatures above $22^{\circ} \mathrm{C}$ are required for Nile tilapia to reproduce normally (Rothbard \& Pruginin 1975; Balarin \& Haller 1982), this study shows that a $22^{\circ} \mathrm{C}$ water temperature can inhibit their spawning.

When the water temperature was raised to $28^{\circ} \mathrm{C}$, significantly higher spawning rates were observed in the treatment groups (14d: $40 \%$ and $28 \mathrm{~d}: 31 \%)$ than in the controls, which were kept at $28^{\circ} \mathrm{C}$ throughout. The spawning rates observed were different from the findings of Srisakultiew and Wee (1988) who reported that exposing spawners to $22^{\circ} \mathrm{C}$ water for one, two or three weeks before restoring an ambient temperature of $29^{\circ} \mathrm{C}$ $-30^{\circ} \mathrm{C}$ did not induce any spawning within four weeks. Furthermore, in the present study, significantly lower hatching rates and lower rates of swim-up fry than in the control were recorded for the eggs fertilised from spawners kept for 2 or 4 weeks at $22^{\circ}$, while the same parameters measured for the eggs that were collected from spawners in experiment 3 ( 1 week) were not significantly different from the control. Srisakultiew and Wee (1988) suggest that reabsorption of the oocytes occurs for females after 1 week of treatment at $22^{\circ} \mathrm{C}$. In their experiment, the percentage of mature eggs and as well as 
the gonadosomal index of females sampled in the second and third week at $22.0{ }^{\circ} \mathrm{C}$ decreased drastically. This could explain why, in the present study, lower hatching rates and lower rates of swim-up fry were observed for eggs from spawners kept at $22^{\circ}$ for 2 or 4 weeks.

Furthermore, in experiment 2, the spawners were kept individually while they were maintained in groups of twelve in experiments 1 and 3. This was done to ease the observation of the females for signs of spawning. In individual compartments, this could be done faster and with less stress to the fish than when the fish were kept in groups. As females in experiment 2 also had the highest spawning rate (40\%) of all the temperature treated fish, individual stocking might have contributed to this improved result. To separate the effect of single stocking from the effect of the temperature treatment, the next experiments were performed with stocking density changes.

\section{Effect of stocking density and photoperiod change}

The stocking density was reduced from a high stocking density in experiment 5 (48 kg $\left.\mathrm{m}^{-3}\right)$ and from a slightly lower stocking density in experiment $7\left(25 \mathrm{~kg} \mathrm{~m}^{-3}\right)$ to a very low stocking density in individual compartments (exp. 5: $7 \mathrm{~kg} \mathrm{~m}^{-3}$, exp. 7: $6 \mathrm{~kg} \mathrm{~m}^{-3}$ ). Depending on the ratio of stocking densities before and after the transfer, a difference in induced spawning rates was observed. A high ratio of stocking densities induced a high spawning rate. In a five day period $40 \%$ of females spawned in experiment 5 (ratio $7: 1$ ), while $25 \%$ of females spawned in repeat 1 of experiment 7 (ratio $4: 1$ ).

In experiment 4 - the control - the stocking density was also reduced from a high stocking density of $48 \mathrm{~kg} \mathrm{~m}^{-3}$ to one of $14 \mathrm{~kg} \mathrm{~m}^{-3}$. However, instead of being transferred to single compartments as in experiment 5 and 7, the spawners were kept in groups of 12. Although the ratio of stocking densities was slightly lower in this experiment - the control (3:1) than in experiment 7 (4:1), the spawning rates diverged more (exp. 5: 18\%, exp. 7 - repeat $1: 25 \%$ ). These results seem to indicate that group stocking has a strong inhibitory effect on spawning. It has been suggested that at high stocking densities, $O$. niloticus females adopt a schooling behaviour which can slow down their reproduction (Balarin, Haller \& Armitage 1986). In Tilapia zillii higher spawning rates have been 
observed when spawners were kept separately to when they were kept together (Coward $\&$ Bromage 1998). Furthermore, 17 $\beta$-oestradiol levels measured in the same females, increased significantly when the fish were confined individually while they remained low and relative constant in the crowded females (Coward \& Bromage 1998). As 17 $\beta$ oestradiol plays an important role during the vitellogenetic phase of the oocyte development. This might indicate why individual confinement is beneficial to the development and maturing of the eggs in the gonads and ultimately result in a higher spawning frequency. Such observations are restricted to $T$. zillii, however, and have yet to be confirmed in $O$. niloticus.

In experiment 5 the females were made to spawn only once, while in experiment 7 this treatment was repeated three times with tagged fish. From repeat 1 to repeat 3, the spawning rate improved from $25 \%$ to $39 \%$ over a period of five days. However, of all the 18 females $(100 \%)$ that had a first spawning event in repeat 1, 8 females (44\%) had a second spawning event while only 5 females $(28 \%)$ had a third spawning event in the course of experiment 7. This indicates that in successive treatments, a smaller proportion of the same fish responded to the repeated treatment. At the same time, the egg quality measured - the percentage of hatchlings and swim-up fry - improved from the first to the third spawning event. In Tilapia zillii, it was found that spawners kept in crowded conditions had a high proportion of atretic eggs (Coward \& Bromage 1998). If this is also applicable to O. niloticus, this could account for poor egg quality of onetime spawners after they were transferred from crowded conditions for the first time and for the improvement in the subsequent spawns.

In experiment $6 \mathrm{a}$ stocking density treatment was combined with a photoperiod of 6L:18D for 21 (experiment 6a) and 28 days (experiment 6b). It was not possible to measure the spawning activity of the females while they were together in a holding tank as checking each female would have caused too much stress to the fish and could have altered the outcome of the experiment. There is evidence that very short periods of light can inhibit spawning in Nile tilapia (Biswas, Morita, Yoshizaki, Maita \& Takeuchi 2005). The very high spawning rate of $65 \%$ measured in experiment $6 \mathrm{a}$, indicates that reproduction might have been strongly suppressed while they were in the holding tank, 
as a large proportion of females spawned once the were moved out (single stocking, 12L:12 D photoperiod).

Interestingly, though the spawners in experiment $6 \mathrm{~b}$ were kept one week longer at $6 \mathrm{~L}: 18 \mathrm{D}$ than in experiment $6 \mathrm{a}$, a much lower spawning rate $(36 \%)$ was observed in the former than in the latter experiment. As both groups of spawners from experiments $6 \mathrm{a}$ and $6 \mathrm{~b}$ were maintained in the same holding tank and the first group was removed one week before the second one, an intermediary reduction of stocking density from $25 \mathrm{~kg}$ $\mathrm{m}^{-3}$ to $13 \mathrm{~kg} \mathrm{~m}^{-3}$ occurred for the second group during a one week period before transfer to individual compartments. This might have been enough of a change in stocking density to cause some of the females to spawn right before they were placed in the solitary compartments, explaining the lower 36\% spawning rate. All egg quality parameters were also higher in experiment $6 \mathrm{~b}$ compared to experiment $6 \mathrm{a}$. If some of the females in experiment $6 \mathrm{~b}$ spawned during individual stocking for the second time during the experiment- assuming they had spawned once already in the holding tank this might account for the better egg quality as it has been shown that eggs collected from a second spawning event have better quality than those from a first spawning event (experiment 7). Further experimentation, without this intermediary change of stocking density is required to confirm this assumption.

As the combination of photoperiod and stocking density changes (experiment $6,21 \mathrm{~d}$ ) was very effective in controlling the spawning of females from the Lake Manzala population, it was also tested on other fish to observe whether they reacted in the same way. Clone crosses of homozygote lines produced by gynogenetic reproduction of mitotic gynogenetic females were selected as they have much smaller variations in their reproductive traits due to a very homogeneous genome within the clone crosses. Due to this homogeneous genome these females would be expected to be stimulated in a more predictable manner by a change in environment and consequently spawn at the same time in larger numbers. The clone cross spawners were subjected to the same conditions as in experiment $6 \mathrm{a}$ (21d). On day three, $6 \%$ of the females spawned, while $35 \%$ of the females spawned on day 4 . The highest daily spawning rate of the clone crosses was observed on day 4 . This peek in spawning rate seems to have set in 1 day later than for 
females that were obtained from normal breeding (Figure 1: day 3). These results suggest that fish with a different genome can also be influenced in their spawning, although the expected outcome of a higher induced spawning rate did not occur in this case. Possibly the right combination of environmental factors which would allow for better spawning rates was not completely achieved.

\section{Selection}

A broad variation in such traits as age at first maturity, fecundity and spawning incidence within the species indicates that performance of the broodstock can be improved by selection (Pullin \& Lowe-McConell 1982; Macaranas, Mather, Lal, Vereivalu, Lagibalavu \& Capra 1997). The high variations in fecundity, proportion of hatchlings and swim-up fry observed in all experiments of the present study suggest that a possible way of improving these parameters and reducing their variation could be to select the females for these traits. Furthermore, if the trigger that causes the females to spawn when their environment is changed in a specific way (change of water temperature, stocking density, and photoperiod) is genetically determined, this might be used to select only the females that react to treatment by spawning. The high proportion of females that never spawned even after repeated treatment in experiment 6 (repeat 1: $75 \%$, repeat $2: 74 \%$ and repeat $61 \%$ ) suggests that these females are not sensitive to the treatment. Selecting those that are, might result in higher spawning rates.

\section{Conclusion}

The number of environmental factors which can potentially influence and cue reproduction is large. Furthermore as several factors may also act at the same time, numerous combinations are possible. Very little is understood about the effect of these external stimuli on hormonal regulation of reproduction in the fish, making it difficult to isolate and describe the effect of each factor. In this study, the suitability of the following factors: water temperature, stocking density and photoperiod, were tested on a large number of Nile tilapia females $(\mathrm{N}=674)$. 
It was shown that a reduced water temperature could be used to induce moderate rates of spawning, though the egg quality was negatively influenced by this change. In the stocking density experiments performed on their own or in combination with a change in photoperiod, moderate to high spawning rates were recorded and the egg quality was on average higher than in the temperature treatments.

Several methods can thus be suggested to manage the production of unfertilised and ovulated eggs of Nile tilapia under practical conditions. The easiest and shortest method which induces a moderate spawning rate with a good egg quality is a simple transfer of females from a high stocking density to a low stocking density in individual compartments. If a maximum number of spawns is desired, a longer $6 \mathrm{~L}: 18 \mathrm{D}$ photoperiod of 21 days should then precede the transfer from group stocking into solitary compartments.

Besides testing other factors or combinations of factors which might have an even stronger influence on the spawning of Nile tilapia, it should also be clarified whether the spawners can be selected for their sensitivity to spawn under these factors. This might be the way to obtain improved control over their spawning and possibly higher egg quality. 


\section{References}

Balarin JD, Haller RD (1982) The intensive culture of tilapia in tanks, raceways and cages. In: Recent advances in aquaculture (ed. by Muir JF, Roberts RJ). Croom Helm, London, pp. 265-355.

Balarin JD, Haller RD, Armitage AT (1986) Research on Intensive Culture of Tilapia in Tanks. In: Aquaculture research in the Africa region: proceedings of the African Seminar on Aquaculture, organised by the International Foundation for Science (IFS), Stockholm (ed Huisman EA). Pudoc, 1986, Wageningen, pp. 206-216.

Biswas AK, Morita T, Yoshizaki G, Maita M, Takeuchi T (2005) Control of reproduction in Nile tilapia Oreochromis niloticus (L.) by photoperiod manipulation. Aquaculture, 243, 229-239.

Coward K, Bromage NR (1998) Histological classification of oocyte growth and the dynamics of ovarian recrudescence in Tilapia zillii. Journal of Fish Biology, 53, 285-302.

Macaranas JM, Mather PB, Lal SN, Vereivalu T, Lagibalavu M, Capra MF (1997) Genotype and environment: A comparative evaluation of four tilapia stocks in Fiji. Aquaculture, 150, 11-24.

Pullin RSV, Lowe-McConell RH (1982) Biology and culture of Tilapias. Proceedings of the international conference on the biology and culture of Tilapias, 2-5 September 1980 at the study and conference center of the Rocherfeller Foundation, Bellagio, Italy

Rothbard S, Pruginin Y (1975) Induced spawning and artificial incubation of Tilapia. Aquaculture, 5, 315-321. 


\section{Acknowledgement}

I wish to express my deep gratitude to Prof. Dr. Hörstgen - Schwark for accepting this thesis and for being of great assistance at all times. Furthermore I would like to express my appreciation to the 'Aquaculture team': Dr. Stephan Wessels, Birgit Reinelt, Uwe Schipke and Andreas Magerhans who all contributed to this work in more ways than one. Lastly, for their constant moral support, my special thanks go to my family and to my dear wife. 


\section{LEBENSLAUF}

Name: de Lapeyre

Vorname: Boris Adrien

Geburtsdatum: 23. Januar 1977

Heimatort: Les Pailles, Mauritius

\section{Berufliche Tätigkeit}

Seit 01/2005 Doktorand

Institut für Tierzucht und Haustiergenetik, Georg-August-Universität Göttingen, D-37073

Göttingen

\section{Wehrdienst}

11/1997 - 08/1998 Luftwaffe

\section{Praktika}

12/1999 - 02/2000 Landwirtschaftlicher Betrieb der Familie Buschhoff, D-48317

Drensteinfurt

09/1999 - 11/1999 Landwirtschaftlicher Betrieb der Familie Niehoff, D-17209 Bütow

03/1999 - 08/1999 landwirtschaftliches Praktikum, Landwirtschaftszentrum Haus Düsse, D59505 Bad Sassendorf

\section{Studium}

2000 - 2004 Studium der Agrarwissenschaften, Fachstudium Wirtschafts- und Sozialwissenschaften des Landbaus, Universität Göttingen, D-37075 Göttingen

\section{Schulen}

1988 - 1996 Kolleg, Collège du Saint Esprit, Quatre Bornes - Mauritius

1982 - 1988 Grundschule, Ecole de Lorette, Les Vacoas - Mauritius 